University of Louisville

ThinkIR: The University of Louisville's Institutional Repository

Electronic Theses and Dissertations

8-2011

\title{
The role of curcumin in response to BPDE-induced DNA damage in human lung epithelial cells.
}

\author{
Erica Nicole Rogers \\ University of Louisville
}

Follow this and additional works at: https://ir.library.louisville.edu/etd

\section{Recommended Citation}

Rogers, Erica Nicole, "The role of curcumin in response to BPDE-induced DNA damage in human lung epithelial cells." (2011). Electronic Theses and Dissertations. Paper 1226.

https://doi.org/10.18297/etd/1226

This Doctoral Dissertation is brought to you for free and open access by ThinkIR: The University of Louisville's Institutional Repository. It has been accepted for inclusion in Electronic Theses and Dissertations by an authorized administrator of ThinkIR: The University of Louisville's Institutional Repository. This title appears here courtesy of the author, who has retained all other copyrights. For more information, please contact thinkir@louisville.edu. 
THE ROLE OF CURCUMIN IN RESPONSE TO BPDE-INDUCED DNA DAMAGE IN HUMAN LUNG EPITHELIAL CELLS

By

Erica Nicole Rogers

B.S., Florida Agricultural and Mechanical University, 2004

M.S, University of Louisville, 2008

\author{
A Dissertation \\ Submitted to the Faculty of the \\ University of Louisville School of Medicine \\ in Partial Fulfillment of the Requirements \\ for the Degree of \\ Doctor of Philosophy \\ Department of Pharmacology and Toxicology \\ University of Louisville \\ Louisville, Kentucky
}

August 2011 

THE ROLE OF CURCUMIN IN RESPONSE TO BPDE-INDUCED DNA DAMAGE IN HUMAN LUNG EPITHELIAL CELLS

By

Erica Nicole Rogers

B.S., Florida Agricultural and Mechanical University, 2004

M.S., University of Louisville, 2008

A Dissertation Approved on

July 20, 2011

By the following Dissertation Committee:

J. Christopher States, Ph.D.

Ramesh C. Gupta, Ph.D.

LaCreis R. Kidd, Ph.D.

Chi Li, Ph.D.

Russell A. Prough, Ph.D. 


\section{DEDICATION}

I dedicate my dissertation work to my family and many friends. I would like to express a special feeling of gratitude to my parents, Frank and Emma Rogers, who have supported me mentally, spiritually, and financially through this long educational journey. Also I would like to thank my sister Ashley Denise Rogers, as well as my best friends: Dr. Jennifer Jones, Tacarra Mauldin, and Rebecca Green for their endless words of encouragement. You all have been my best cheering squad and I deeply appreciate that.

I also would like to dedicate this dissertation to my many friends, lab colleagues, and the Black Biomedical Graduate Student Organization (BBGSO) for supporting me throughout this process. I will always appreciate the scientific input, professional development and emotional support you provided me through my graduate school career 


\section{ACKNOWLEDGMENTS}

I would like to thank my mentor, Dr. J. Christopher States, for his guidance and patience. I would also like to thank the other committee members, Drs. Ramesh Gupta, LaCreis Kidd, Russell Prough, and Chi Li, for their suggestions and comments over the past five years. I would also like to thank my parents, Mr. and Mrs. Frank Rogers, as well as my sister, Ashley Denise Rogers, for keeping me grounded through this long educational journey. 


\begin{abstract}
THE ROLE OF CURCUMIN IN RESPONSE TO BPDE-INDUCED DNA DAMAGE IN HUMAN LUNG EPITHELIAL CELLS

Erica Nicole Rogers

July 20, 2011
\end{abstract}

Long-term exposure to harmful carcinogens like benzo[a]pyrene (BaP) are linked to lung cancer. Benzo[a]pyrene diol epoxide (BPDE), the ultimate carcinogen produced by $\mathrm{BaP}$ bioactivation, is believed to play an important role in lung carcinogenesis. The tumor suppressor protein is p53 signals cell cycle arrest, DNA repair, and apoptosis in response to BPDE-induced damage. However, physiological exposure to BPDE fails to activate p53. Although the bioactive principle of turmeric spice, curcumin, shows promising effects against BPDE-induced carcinogenesis, its exact mode of action remains unclear. Therefore the aim of this dissertation was to investigate whether curcumin prevents BPDE-induced DNA damage by regulating p53-mediated cellular responses in A549/LXSN (p53+) and A549/E6 (p53-) cells. I hypothesize that curcumin may reduce BPDE-induced DNA damage by lowering the threshold of $p 53$ activation, thereby inducing p53-mediated mechanisms. Curcumin pretreatment reduced BPDEDNA adducts in a p53-dependent manner. However, p53-regulated proteins XPC and DDB2 did not change with curcumin pretreatment and p53-expression. Curcumin pretreatment did not change the overall repair rate in p53+cells. Curcumin pretreatment, p53-expression, and BPDE exposure did not significantly change glutathione-S- 
transferase (GST) levels or activity as well as glutathione (GSH) levels. Curcumin increased levels of p53, phosphorylated p53 at Ser15 (P-p53S15), and CDKN1A, but decreased phosphorylated retinoblastoma at Ser807/811 (P-pRbS807/811) in p53+ cells with lower BPDE exposure. Curcumin and BPDE increased and decreased PpRbS807/811, respectively, in p53- cells. BPDE induced S phase arrest in both cell lines. P53+ curcumin pretreated cells escaped S phase arrest earlier with $300 \mathrm{nM}$ BPDE in contrast to BPDE treatment alone. Yet, curcumin did not change $S$ phase arrest in p53+ cells treated with 50 or 100 nM BPDE. P53- cells did not escape S phase arrest 24 $\mathrm{h}$ after low (50 and $100 \mathrm{nM}$ ) BPDE exposures; p53- curcumin pretreated cells entered S phase arrest earlier. Phosphorylated CHK1Ser345 (pCHKS345) levels, an indicator of S phase arrest, was higher in p53- cells than p53+ cells; curcumin increased pCHK1Ser345. Curcumin also induced apoptosis earlier in p53- cells exposed to 300nM BPDE. Therefore, this dissertation shows that curcumin prevents BPDE-induced DNA damage by activating a host of mechanisms independent of p53 expression. 
TABLE OF CONTENTS

PAGE

DEDICATION

iii

ACKNOWLEDGMENTS

iv

ABSTRACT

LIST OF FIGURES

v-vi

ix-xi

Chapter I: INTRODUCTION

Chapter II: CURCUMIN PRETREATMENT REDUCED BPDE-INDUCED

DNA DAMAGE IN A P53-DEPEDNENT MANNER

INTRODUCTION

MATERIALS AND METHODS

RESULTS

$33-49$

DISCUSSION

$50-55$

Chapter III: CURCUMIN AFFECTS CELL CYCLE ARREST AND

APOPTOSIS IN HUMAN LUNG EPITHELIAL CELLS IN RESPONSE

TO BPDE-INDUCED DNA DAMAGE

INTRODUCTION

$56-58$

MATERIALS AND METHODS

$59-60$

RESULTS

$61-71$

DISCUSSION

$72-74$

Chapter IV: GENERAL DISCUSSION

75-77

Chapter V: FUTURE DIRECTIONS

78-79

REFERENCES

80-93

APPENDIX: LIST OF ABBREVIATIONS

94-96 
CURRICULUM VITAE

97-100 


\section{LIST OF FIGURES}

FIGURE

PAGE

1. PATHWAYS OF B(A)P METABOLISM

2. BIOACTIVATION OF BENZO(A)PYRENE TO THE ULTIMATE CARCINOGEN 7R,8S-DIHYDROXY-9S,10R-EPOXY-7,8,9,10TETRAHYDROBENZO(A)PYRENE (BPDE) 5

3. TWO STEREOISOMERIC FORMS OF BPDE-DNA ADDUCTS 6

4. ACTIVATED P53 SIGNALS A NUMBER OF RESPONSES 8

5. ACTIVATED P53 SIGNALS G1/S CHECKPOINT 9

6. NUCLEOTIDE EXCISION REPAIR PATHWAYS 11

7. STRUCTURE OF THE CURCUMINOIDS: CURCUMIN, DEMETHOXYCURCUMIN AND BISDEMETHOXYCURCUMIN

8. CHEMICAL STRUCTURES OF MAJOR METABOLITES OF CURCUMIN IN RODENTS AND HUMANS

9. ACTIVATED P53 SIGNALS THE UP-REGULATION OF DNA DAMAGE RECOGNITION PROTEINS XPC AND DDB2 IN RESPONSE TO DNA DAMAGE 22

10. OVERALL EXPERIMENTAL DESIGN FOR ALL STUDIES 24

11. IMMUNOSLOT BLOT ANALYSIS OF BPDE-DNA ADDUCTS IMMEDIATELY AFTER 1 HOUR BPDE TREATMENT

12. WESTERN BLOT ANALYSIS OF P53 AND XPC IMMEDIATELY (0 H) AND 24 H AFTER BPDE TREATMENT 
13. RELATIVE XPC LEVELS IMMEDIATELY $(0 \mathrm{H})$ AND $24 \mathrm{H}$ AFTER BPDE TREATMENT

14. WESTERN BLOT ANALYSIS OF P53 AND DDB2 LEVELS IMMEDIATELY $(0 \mathrm{H})$ AND $24 \mathrm{H}$ AFTER BPDE TREATMENT

15. RELATIVE DDB2 LEVELS IMMEDIATELY $(0 \mathrm{H})$ AND 24 H AFTER BPDE TREATMENT

16. WESTERN BLOT ANALYSIS OF P53 AND DDB2 LEVELS

24 HOURS AFTER DNA DAMAGE IN DIFFERENT CELL TYPES

WITH DIFFERENT TREATMENTS

17. IMMUNOSLOT BLOT ANALYSIS OF BPDE-DNA ADDUCTS REMAINING IMMEDIATELY (0), 6 AND 24 H AFTER BPDE TREATMENT

18. GSTA AND GSTM ARE NOT PRESENT IN A549 CELLS

19. EFFECTS OF CURCUMIN PRETREATMENT AND P53 EXPRESSION ON GST PROTEIN LEVELS AND ACTIVITY

20. EFFECTS OF CURCUMIN PRETREATMENT AND P53 EXPRESSION ON GST PROTEIN LEVELS AND ACTIVITY

21. EFFECTS OF CURCUMIN PRETREATMENT AND P53

EXPRESSION ON THE ACTIVITY ON CELLULAR-REDUCED GSH LEVELS

22. POSSIBLE MECHANISM BY WHICH CURCUMIN REDUCES BPDE-DNA ADDUCTS

23. STRUCTURES OF CURCUMIN AND ELLAGIC ACID

24. CURCUMIN ENHANCES P53 AND CDKN1A INDUCTION IN RESPONSE TO BPDE-INDUCED DAMAGE. 
25. P53-EXPRESSING A549/LSXN CELLS TRANSIENTLY ARREST

IN S-PHASE IN RESPONSE TO BPDE-INDUCED DAMAGE.

26. P53-DEFICIENT A549/E6 CELLS ARREST IN S PHASE, BUT NEVER ESCAPE WITH LOWER BPDE CONCENTRATIONS.

27. LEVELS OF CYCLIN A AND E IN RESPONSE TO CURCUMIN PRETREATMENT AND EXPOSURE TO BPDE

28. P-CHK1SER345 IS ACTIVATED IN P53-DEFICIENT CELLS AFTER BPDE TREATMENT

29. CURCUMIN ENHANCES APOPTOSIS IN APOPTOSIS IN A549/E6 CELLS IN RESPONSE TO 300 NM BPDE. 


\section{CHAPTER I}

\section{GENERAL INTRODUCTION}

\section{Overview}

Lung cancer remains one of the most common causes of cancer-related deaths in America [1-4]. Despite major surgical and therapeutic improvements in the treatment and management of this disease, these methods are unsuccessful in reducing the overall mortality rate of lung cancer. As a result, alternative methods are needed to control this disease. Because lung cancer is primarily caused by long-term exposure to environmental carcinogens, much research has been devoted to discovering better ways to inhibit the process of carcinogenesis. Chemoprevention is a rapidly growing area focused on preventing, hampering, arresting or reversing the process of carcinogenesis. The naturally-occurring agent, curcumin, the major bioactive constituent in turmeric, has shown promising activity against cancer. Traditionally known for its uses in Indian cooking and medicine, curcumin has shown promising effects in combating the carcinogenic activity of chemicals such as benzo(a)pyrene (BaP) [5-7].

$\mathrm{BaP}$ is a well known carcinogenic compound present in tobacco smoke, charbroiled food, and coal tar [8-10]. The highly reactive and mutagenic metabolite of $\mathrm{BaP}, 7 R, 8 S$-dihydroxy-9S,10R-epoxy-7,8,9,10-tetrahydrobenzo[a]pyrene (BPDE), is believed to play an important role in lung carcinogenesis by damaging DNA [11;12]. The tumor suppressor protein p53 is known to respond to DNA damage by signaling cell cycle arrest, DNA repair, and apoptosis [13-15]. In addition, BPDE can be inactivated by the glutathione (GSH) detoxification pathway [16;17]. Although p53 is activated in 
response to BPDE-induced DNA damage, physiological exposure to BPDE is relatively low and fails to activate p53. As a result, failure to activate p53 in response to BPDEinduced DNA damage leads to an increase likelihood of mutations. An increase in mutations may ultimately lead to cancer. This project focuses on how curcumin may play a significant role in decreasing the carcinogenic activity of BPDE. Specifically, this dissertation focuses on whether curcumin reduces BPDE-induced DNA damage by lowering the threshold of p53 activation and subsequent DNA repair and cell cycle pathways.

Chapter two of this dissertation examines whether curcumin modulates DNA repair and BPDE detoxification pathways in a p53-dependent manner. Data show that curcumin significantly lowered BPDE-DNA adducts only in p53-expressing cells. However, curcumin did not change the overall repair rate of BPDE-induced DNA damage in a p53-dependent manner. In addition, curcumin and p53-expression did not play a role in the GSH detoxification pathway.

Chapter three of this dissertation investigated if curcumin affects the regulation of p53 and p53-mediated cell cycle progression in response to BPDE-induced DNA damage. Curcumin changed cell cycle arrest mechanisms in p53+ and p53- cells in response to BPDE-induced DNA damage.

\section{Lung Cancer}

Lung cancer is one of the most common cancers worldwide, accounting for 1.3 million deaths annually [18]. In the United States, lung cancer is the leading cause of cancer-related deaths among men and women [19]. It is estimated that exposure to environmental carcinogens causes $90 \%$ of all reported lung cancer cases.

Environmental carcinogens are commonly present in polluted air and water [2023] , tobacco products and their smoke [24;25], charbroiled food and smoke [26-28], and occupational environments [29;30]. One of the most widespread environmental 
carcinogens is polycyclic aromatic hydrocarbons (PAHs) [10;31;32].

\section{Polycyclic Aromatic Hydrocarbons}

PAHs are a major class of carcinogenic chemicals formed by incomplete combustion of organic matter [9]. Typically, these carcinogens are metabolically activated in the body by the cytochrome P450 (CYP) system into electrophilic derivatives that covalently bind to DNA [8;33]. The binding of PAHs to DNA forms bulky adducts that can lead to mismatched base pairing. If PAH-DNA adducts are not removed, mutations may result, which ultimately can lead to cancer [34].

\section{Benzo(a)pyrene (BaP)}

Benzo(a)pyrene $(\mathrm{BaP})$ is a well characterized $\mathrm{PAH}$ that can be converted into a number of metabolites [35-38] (Figure 1). BaP is characterized by a bay region which possesses a rigid, planar structure. It is well established that $7 R, 8 S$-dihydroxy-9S,10Repoxy-7,8,9,10-tetrahydrobenzo(a)pyrene (BPDE) is the most reactive carcinogen formed by BaP bioactivation [36] (Figure 2). BPDE can bind to nucleophilic centers of macromolecules. However, BPDE preferentially reacts with the exocyclic amino groups of guanine to form bulky adducts on DNA. Thus, the major BPDE-DNA adducts are formed with guanine bases ( $\left.N^{2}-B P D E-d G\right)$. BPDE binds to guanine either with the pyrene system within the minor groove (trans) or "intercalated" into the DNA (cis) [31] (Figure 3). In mammalian cells, trans-BPDE-DNA adducts are more mutagenic than cisBPDE-DNA adducts $[37 ; 39 ; 40]$. Commonly if these adducts are bypassed or not repaired, adducted guanine pairs with adenine instead of cytosine during DNA replication. Consequently, during the next cell division cycle adenine, the wrong base, will pair with thymine. As a result, a point mutation will occur known as a $G$ to $T$ transversion. BPDE-induced $\mathrm{G}$ to $\mathrm{T}$ transversions are known to occur in key genes related to tumor development, including proto-oncogenes of the ras family as well as tumor suppressor genes such as p53 [10]. As a result, detrimental effects such as 


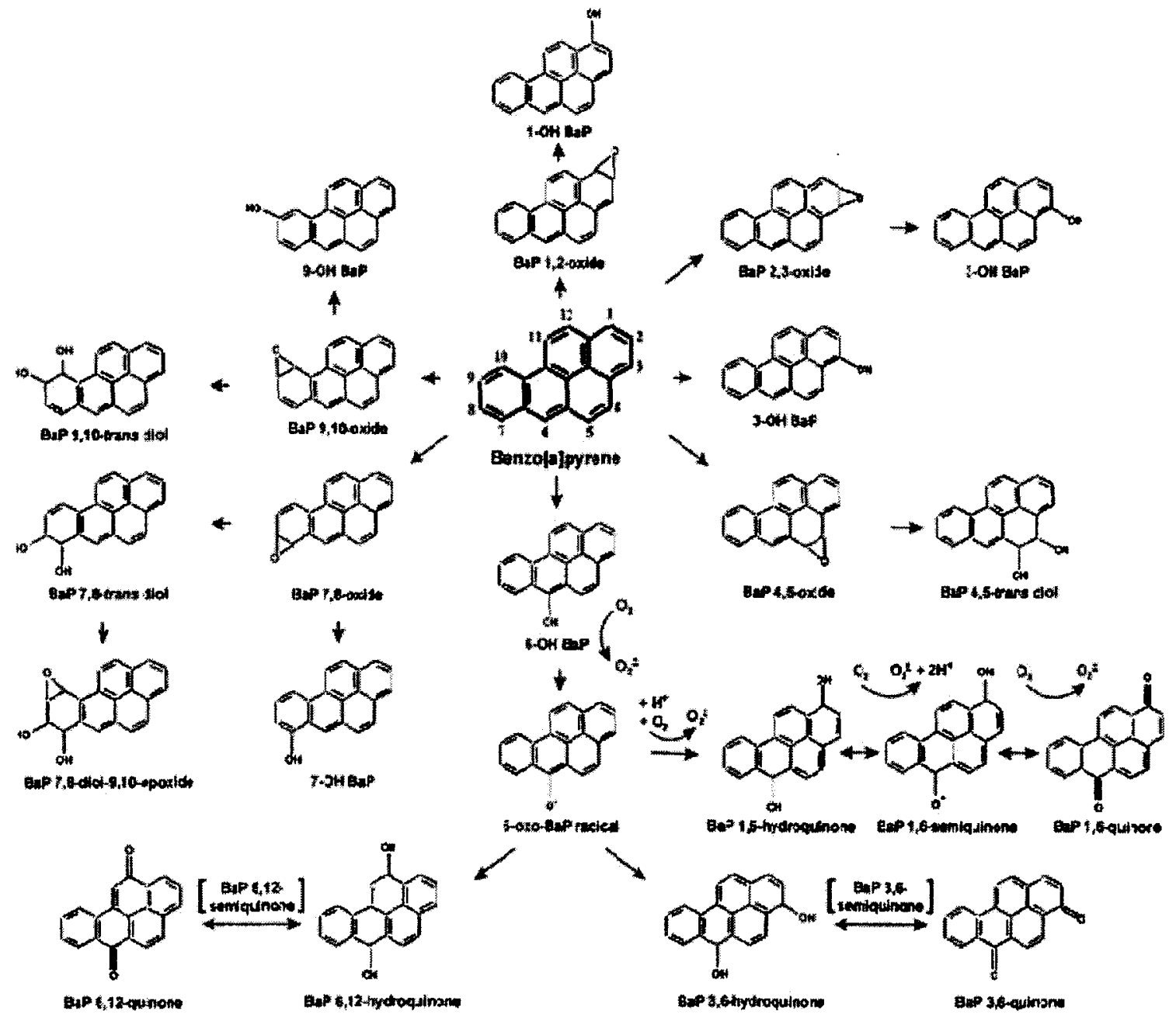

Figure 1. Pathways of $\mathrm{B}(\mathrm{a}) \mathrm{P}$ metabolism. Adapted from "Impact of Cellular Metabolism on the Biological Effects of Benzo[a]pyrene and Related Hydrocarbons," by Kimberly Miller, 2001, Drug Metabolism Reviews, 33 (1), p. 1-35. 
<smiles>Brc1cccc2c1C=Cc1cccc3cccc-2c13</smiles>

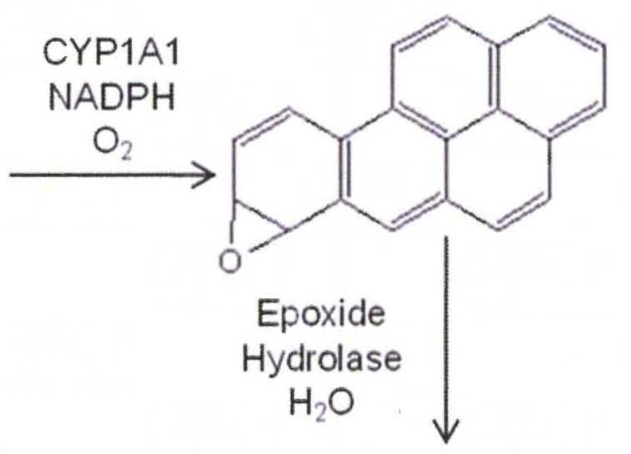

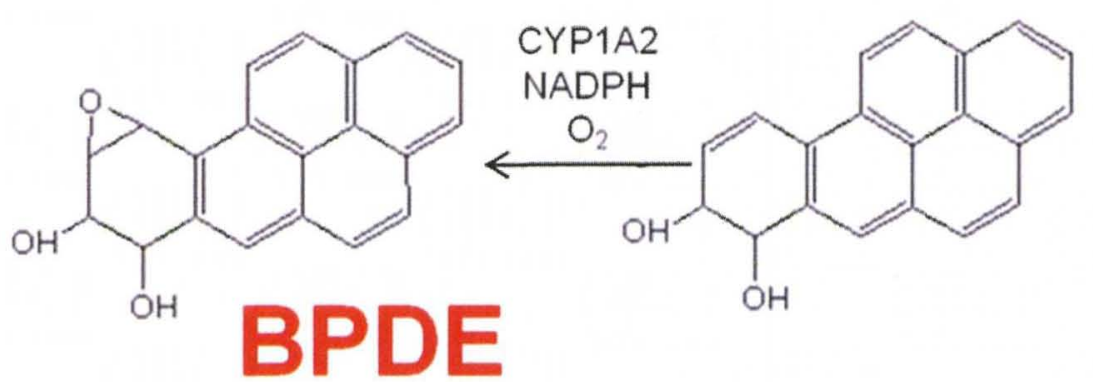<smiles>O=c1[nH]c(NC2c3c(cc4ccc5cccc6ccc3c4c56)C(O)C(O)C2O)nc2c1ncn2O</smiles>

Figure 2. Bioactivation of benzo(a)pyrene to the ultimate carcinogen $7 R, 8 S$-dihydroxy9S,10R-epoxy-7,8,9,10-tetrahydrobenzo(a)pyrene (BPDE). BPDE primarily reacts with the exocyclic amino group of guanine. Adapted from "Application of biologically based computer modeling to simple or complex mixtures," by K.H. Liao, 2002, Environ. Health Perspect. 110 Suppl 6, p. 957-963. 

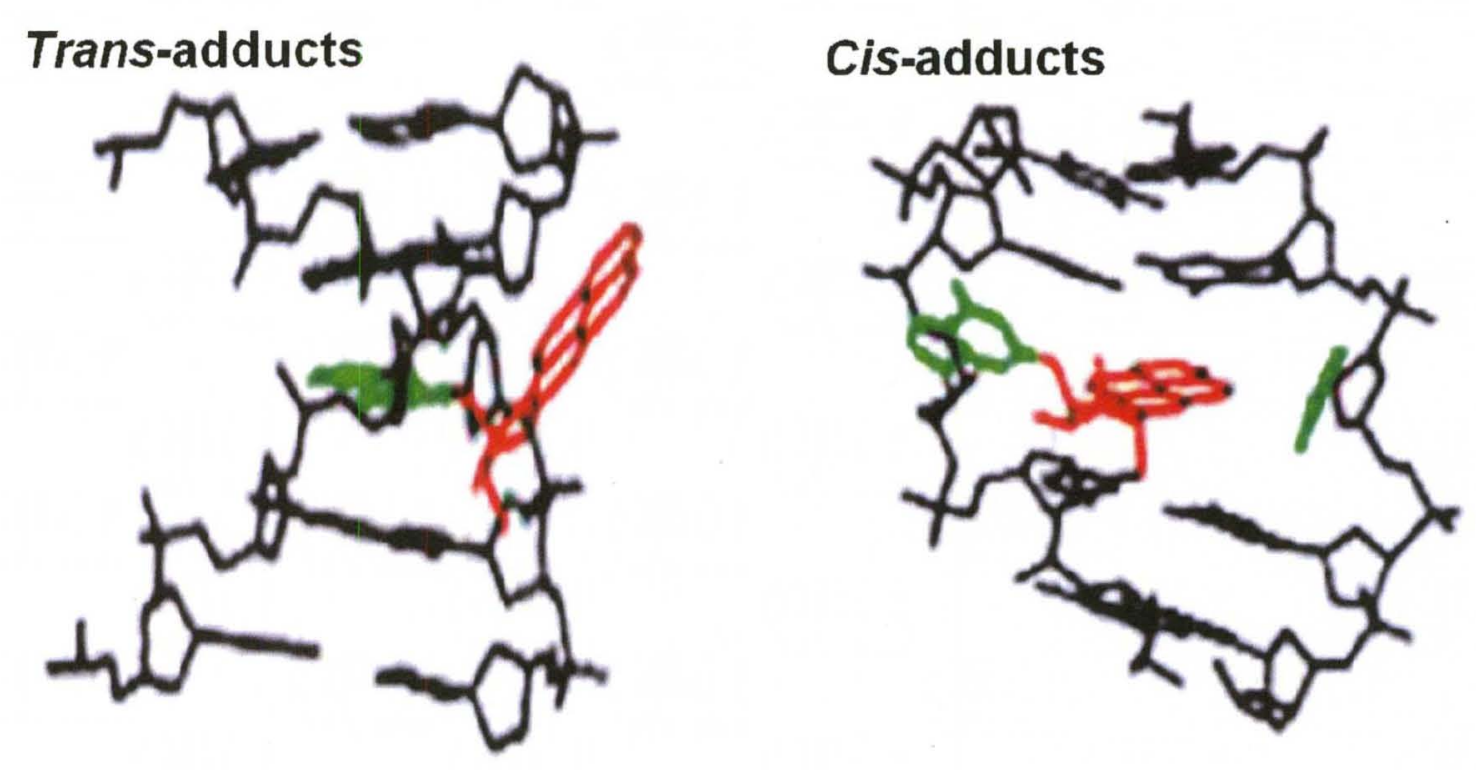

Figure 3. Two stereoisomeric forms of BPDE-DNA adducts. BPDE binds to guanine either with the pyrene system within the minor groove (trans) or "intercalated" into the DNA (cis). Black=DNA backbone; green= guanine; and red= $\mathrm{N}^{2}-\mathrm{BPDE}-\mathrm{dG}$. Adapted from "Origins of conformational differences between cis- and trans-DNA adducts derived from enantiomeric anti-benzo[a]pyrene diol epoxides," by X.M. Xie, 1999, Chem. Res. Toxicol. 12(7), p. 597-609. 
cytotoxicity and inhibition of DNA synthesis can occur which disrupt the integrity of genetic material.

\section{P53 responses to DNA damage}

Several cellular responses to DNA damage help to prevent mutations from occurring. One of the most common cellular responses to BPDE-induced DNA damage is the stabilization and activation of the tumor suppressor protein p53 [15]. In unstressed cells, p53 transactivation is inhibited by the E3 ubiquitin ligase, human double minute-2 (HDM2). HDM2 regulates p53 activity in two ways: (1) it binds and blocks the transactivation domain of p53; and (2) it conjugates ubiquitin molecules onto p53, which signals p53 degradation by the proteasome [41]. In response to DNA damage, p53 is phosphorylated in its transactivation domain and dissociates from HDM2 [41-43]. Phosphorylation of p53 increases its stability and function. Stabilization and additional posttranslational modifications subsequently activate p53. Activation of p53 up-regulates cell cycle arrest, DNA repair, or apoptosis, depending on the type and duration of DNA damage $[13 ; 44 ; 45]$ (Figure 4).

\section{P53 and Cell Cycle Arrest}

Activated p53 inhibits the interaction between cyclins and cyclin dependent kinases (CDKs), which signals cell cycle arrest [46-49]. Activated p53 signals G1 or G2 arrest. G1 arrest is important because it prevents replication of damaged DNA. P53mediated transcriptional activation of CDK inhibitor CDKN1A (sometimes termed p21 ${ }^{\text {WAF1/CIP1 }}$ ) commonly induces G1 arrest [50;51] (Figure 5). CDKN1A prevents interactions between cyclin E-CDK2 and cyclin D-CDK4/6 thereby preventing the phosphorylation of retinoblastoma protein $(\mathrm{pRb})$. As a result, $\mathrm{pRb}$ remains bound to and inactivates E2F1. E2F1 is one of several transcription factors responsible for the regulation of genes required for S phase progression. P53 can also activate several downstream targets responsible for G2 arrest, including CDKN1A, GADD45, and 


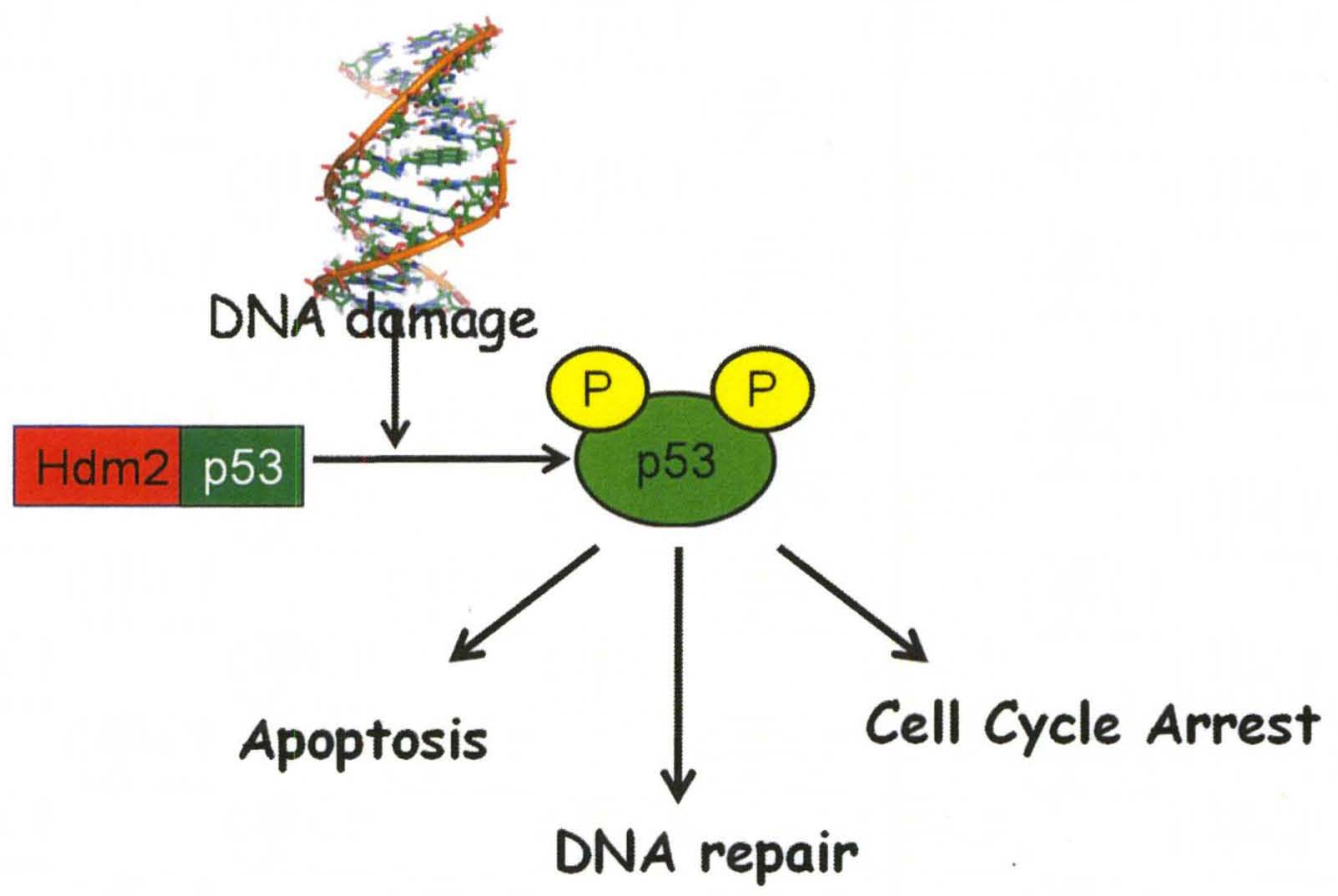

Figure 4. Activated p53 signals a number of responses. In unstressed cells, p53 remains bound to and inactivated by HDM2 via degradation. In response to DNA damage p53 undergoes stabilization and activation to signal cell cycle arrest, DNA repair, and apoptosis. 


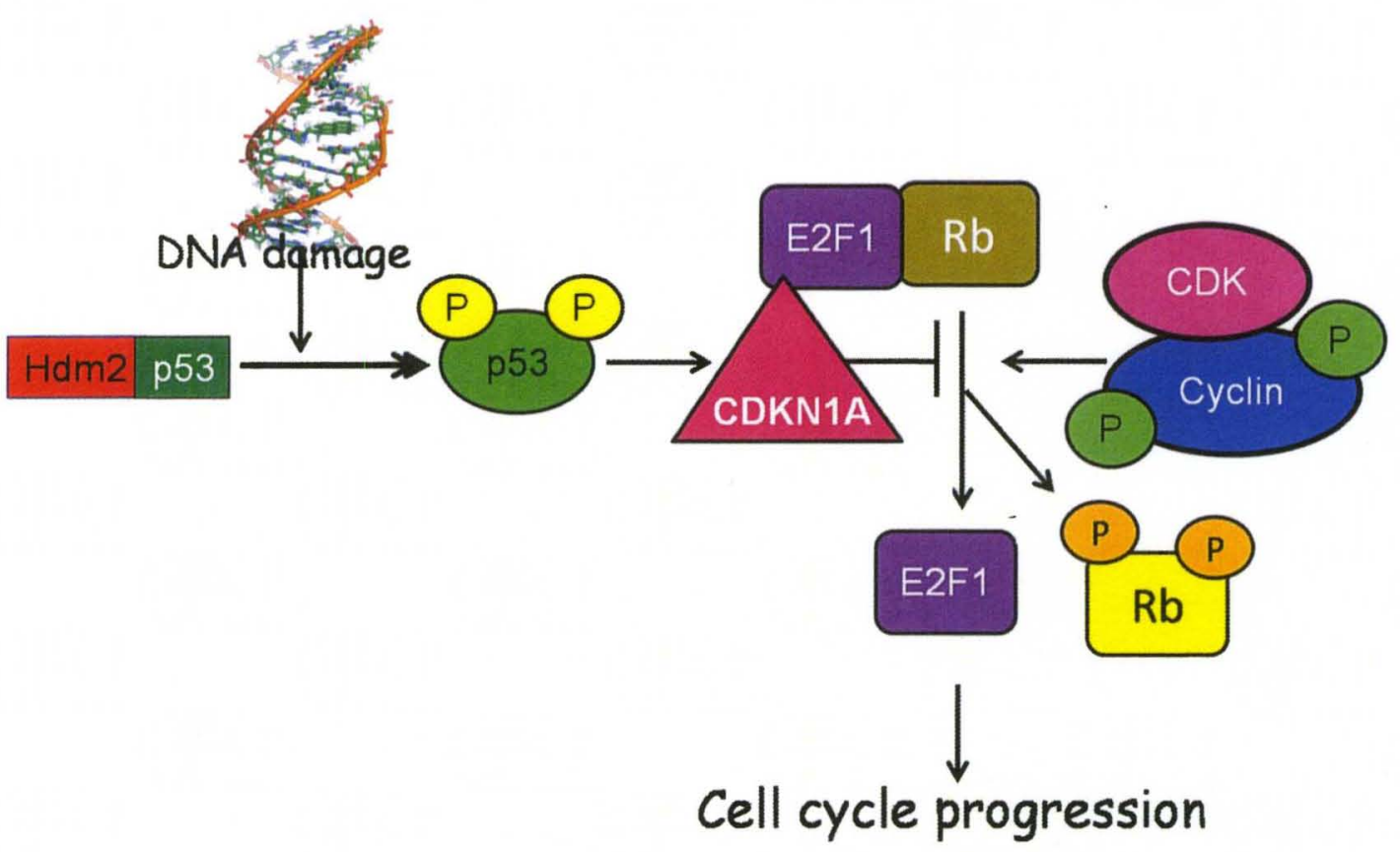

Figure 5. Activated p53 signals G1/S checkpoint. During G1 progression, cyclins and CDKs are allowed to interact with each other. The interactions between the cyclin-CDK complexes phosphorylate retinoblastoma $(\mathrm{Rb})$. As a result, $\mathrm{Rb}$ becomes hyperphosphorylated. Hyperphosphorylation of Rb releases E2F1 which results activation of genes required for $S$ phase entry. In response to DNA damage, p53 is stabilized and activated to up-regulate CDKN1A, a CDK inhibitor. Up-regulation of CDKN1A inhibits the binding of cyclins to CDKs, thus leaving Rb hypophosphorylated. Hypophosphorylated Rb remains bound to E2F1 and inhibits cell cycle progression. 


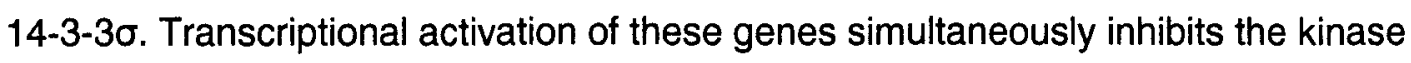
activity of CDK1 with cyclin B (cyclin B-CDK1). Cyclin B-CDK1 complex is necessary for entry into the $\mathrm{M}$ phase. In cases where DNA cannot be repaired, p53 initiates apoptosis.

\section{P53 and Global Genomic Repair}

Besides regulating cell cycle arrest and apoptosis, p53 plays a critical role in nucleotide excision repair (NER) [52]. NER is the major DNA repair pathway for the removal of adducts induced by UV light and bulky chemicals such as BPDE [53-56]. The NER system involves five steps: (1) DNA damage recognition, (2) multi-protein excision complex assembly, (3) excision of the damage, (4) gap filling with correct DNA, and (5) sealing of the new DNA with the original undamaged portion (Figure 6). NER is divided into two distinct subpathways: transcription coupled repair (TCR) and global genomic repair (GGR). In TCR, RNA polymerase II recognizes damage on the transcribed DNA strands of active genes. On the other hand, GGR protein complexes DNA damage binding protein 1/2 (DDB1/DDB2) and Xerderma pigmentosum group C/human UV excision repair protein RAD23 homolog B (XPC/HR23B) recognize damage in both nontranscribed and transcribed genes. GGR effectively removes bulky adducts formed by BPDE [52].

Further, p53 mediates the basal and inducible expression of DNA damage recognition genes XPC and DDB2 [57-60]. While activated p53 up-regulates a host of cellular protective mechanisms, environmental exposure to BPDE is relatively low ( $\leq 100$ $\mathrm{nM})$. As a result, p53 remains inactive, thereby preventing its ability to act as a protective mechanism against DNA damage.

\section{BPDE Detoxification}

In addition to removing DNA damage, several other mechanisms protect DNA by converting BPDE to inactive forms. These mechanisms include: BPDE hydrolysis to tetrols and keto diols, and BPDE conjugation with glutathione (GSH). Conversion of 


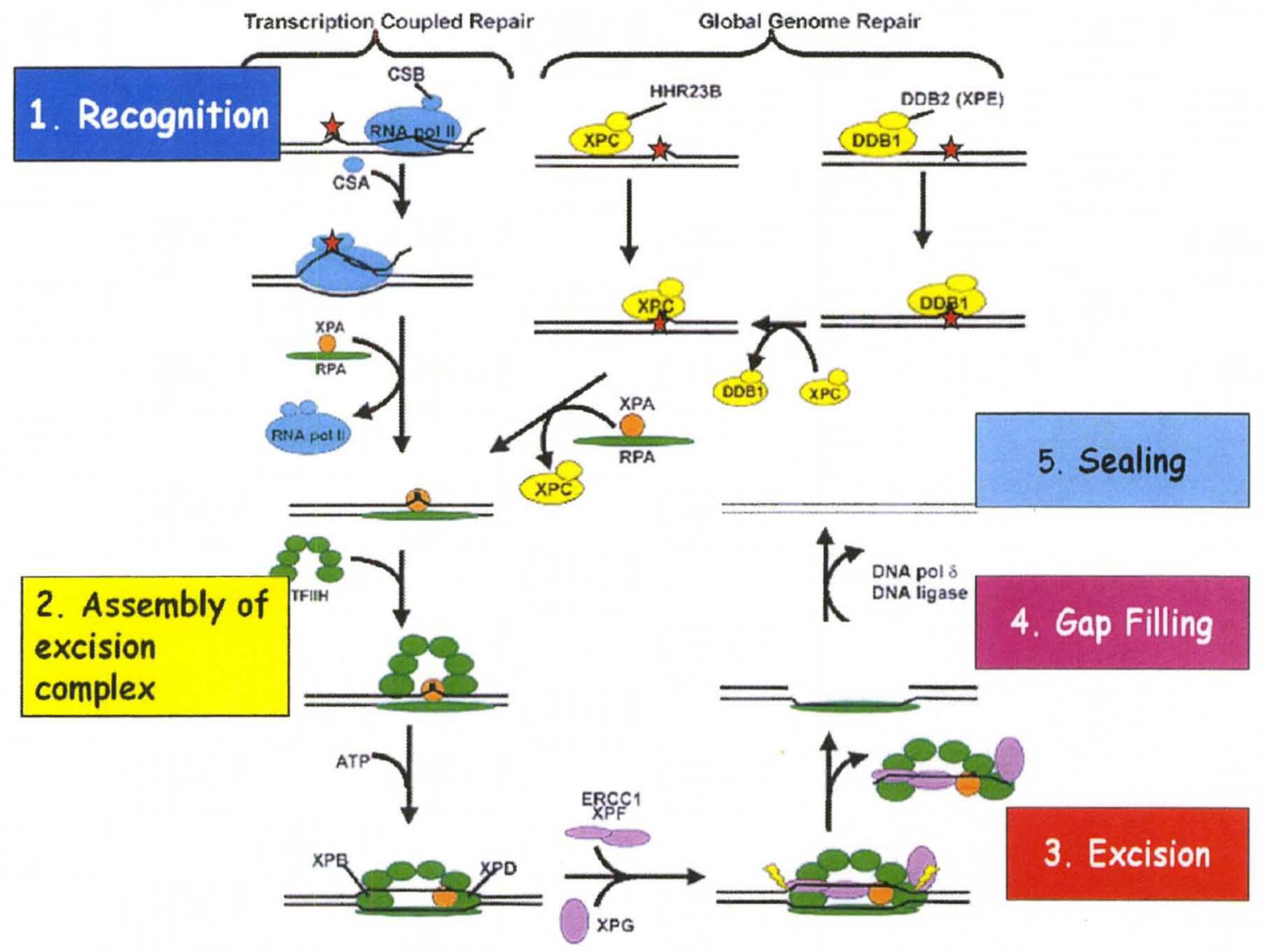

Figure 6. Nucleotide excision repair pathways. NER process involves five steps:

damage recognition, multi-protein complex assembly, damage excision, gap filling, and ligation. Depending on how the DNA lesion (red star) is recognized, the NER system is either referred to as transcription coupled repair (TCR) or global genomic repair (GGR). Adapted from "Discovery and Functional Analysis of XPA Polymorphisms and use of Telomerase Immortalized cells for Nucleotide Excision Repair Studies," by P.C. Porter, 2005, dissertation, p. 8. 
BPDE to inactive forms prevents the interaction between BPDE and DNA. Conjugation of BPDE with GSH is the most important detoxifying mechanism against BPDE. Glutathione-(S)- transferases (GSTs) catalyze the reaction between BPDE and GSH to produce inert, hydrophilic compounds [61-63] (Figure 1). Additionally a possible correlation between GST and p53 expression has been suggested [64;65]. For example, it was found that expression of GSTP did not significantly modify the life span and the tumor spectrum in p53 knockout mice. Thus, these results suggested that the influence of p53 on tumor development may mask the possible role of GSTP in response to carcinogen-induced DNA damage. Overall, however, it is not fully understood whether the GSH system influences cellular mechanisms such as p53 in response to chemical insults such as BPDE.

\section{Curcumin as a Chemopreventive Agent}

Techniques such as surgical resection, radiation ablation, and chemotherapy currently manage and control lung cancer. However, in most cases, lung cancer is not detected until it has metastasized to other parts of the body [1]. As a result, the overall survival rate for lung cancer is fairly low [66]. In turn, many researchers are investigating alternative approaches to control the onset of lung cancer. Because this disease is primarily caused by long-term exposure to environmental carcinogens, much cancer research is devoted to discovering innovative ways to inhibit carcinogenesis. One of the current approaches includes the use of dietary constituents including curcumin $[67 ; 68]$.

\section{Chemical Structure, Properties, and Biotransformation of Curcumin}

Curcumin (diferuloylmethane) is a major constituent of turmeric powder which is extracted from the rhizomes of the plant Curcuma longa Linn (Figure 7) [69]. Curcumin is a polyphenolic compound with a $\beta$-diketone moiety [70]. It contains two ferulic acid molecules linked via a methylene bridge at the $C$ atom of the carboxyl group. Many studies speculate that the biological activity of curcumin resides in either the double 
bonds of the alkene part of the molecule, the hydroxyl groups of the benzene rings, and/or the central $\beta$-diketone moiety. Commercial curcumin contains curcumin I $(\sim 77 \%)$, demethoxycurcumin $(\sim 17 \%)$, bisdemethoxycurcumin $(\sim 3 \%)$ as its major components [71;72]. Curcumin is relatively insoluble in water, but dissolves in acetone, dimethylsulfoxide, and ethanol [72]. Curcumin is unstable in neutral basic $\mathrm{pH}$ environmental. Curcumin instability at neutral and basic $\mathrm{pH}$ leads to degradation of curcumin within 30 minutes to trans-6-(4'-hydroxyphenyl)-2, 4,-dioxo-5-hexenal, ferulic acid (4-hydroxy-3-methoxycinnamic acid), ferulonyl methane (4-hydroxy-3methoxycinnamonyl-methane) and vanillin [73;74].The amount of vanillin increased with incubation time. Curcumin in the presence of fetal calf serum or human blood, or addition of antioxidants such as ascorbic acid, $\mathrm{N}$-acetylcysteine or glutathione, completely prevent the degradation of curcumin in culture media or phosphate buffer above $\mathrm{pH}$ 7. Curcumin is more stable in cell culture media containing $10 \%$ fetal calf serum or in human blood, with less than $20 \%$ decomposition within 1 hour compared to $90 \%$ within 30 minutes in serum-free medium [75-78]. After incubation for 8 hours, about $50 \%$ of curcumin still remained in serum-containing medium.

The absorption, metabolism, and tissue distribution of curcumin in rodents and humans is well characterized. In rats, $75 \%$ of a $1 \mathrm{~g} / \mathrm{kg}$ dose of curcumin was excreted in the feces. Negligible amounts of curcumin were found in rats' urine [79]. In another study, $60 \%$ of oral curcumin administered to rats was absorbed, while glucuronide and sulfate conjugates were found in urine. When the bioavailability of curcumin was studied from this same group, $\left[{ }^{3} \mathrm{H}\right]$-radiolabelling showed that majority of an oral dose of curcumin was excreted in the feces [75]. Consequently, only one-third of curcumin was excreted in an unmetabolized form. Intravenous and intraperitoneal administration of curcumin in rodents resulted in large quantitied of curcumin and metabolites in bile, which were characterized mainly as tetrathydrocurcumin and 
<smiles>COc1cc(/C=C/C(=O)/C=C(O)/C=C/c2ccc(O)c(OC)c2)ccc1O</smiles><smiles>COc1cc(/C=C/C(O)=C/C(=O)/C=C/c2ccc(O)cc2)ccc1O</smiles><smiles>O=C(/C=C/C(O)=C/c1ccc(O)cc1)/C=C/c1ccc(O)cc1</smiles>

Bis-Demethoxy curcumin

Figure 7. Structure of the curcuminoids curcumin, demethoxycurcumin and bisdemethoxycurcumin. Adapted from "Curcumin: A review of anti-cancer properties and therapeutic activity in head and neck squamous cell carcinoma,"

By R. Wilken, 2011. Molecular Cancer 2011 p 10:12. 
hexahydrocurcumin glucuronides (Figure 8). This study suggested that curcumin undergoes transformation during absorption via the intestine and possibly is subjected to entero-hepatic recirculation [77]. Another study of intraperitoneal curcumin administered to mice suggested that curcumin was first biotransformed to dihydrocurcumin and tetrahydrocurcumin, and that these compounds were subsequently converted to monoglucuronide conjugates [78]. Oral curcumin administered to rats using high pressure liquid chromatography (HPLC) demonstrated small amounts of curcumin in plasma with higher levels of curcumin glucuronide and curcumin sulfate in plasma, and small quantities of hexahydrocurcumin, hexahydrocurcuminol and hexahydrocurcumin glucuronide. Metabolism of curcumin in humans, however, is poorly understood.

Preclinical work in human hepatocytes, liver, and gut microsomes suggested that metabolic reduction of curcumin occurred very rapidly. Additionally, co-administration of piperine along with curcumin, in rats, increased systemic bioavailability of curcumin as much as $154 \%$ [72]. Piperine is known as a constituent of pepper vine, piper nigrum, hot jalapeno peppers, and peppercorns. To be brief, curcumin exhibits low oral bioavailability in rodents and may undergo intestinal metabolism; absorbed curcumin undergoes rapid first-pass metabolism and excretion in the bile. Consequently, transformation of curcumin to curcumin-glucuronoside, dihydrocurcumin-glucuronoside, THC-glucuronoside, and THC has been implicated to play critical roles in curcumininduced biological activites $[16 ; 80 ; 81]$.

\section{Curcumin and BPDE}

Widely known for its uses in Indian cooking and traditional Chinese medicine, curcumin has shown promising activity against many diseases such as lung cancer [82]. Specifically, several models have shown that curcumin impedes the carcinogenic activity for many chemicals including BaP. Curcumin, for example, prevented BaP-induced tumorigenesis in mice by increasing the detoxification of BPDE in liver [5;7]. Additionally, 
<smiles>COc1cc(/C=C/C(=O)/C=C(O)/C=C/c2ccc(O)c(OC)c2)ccc1O</smiles>

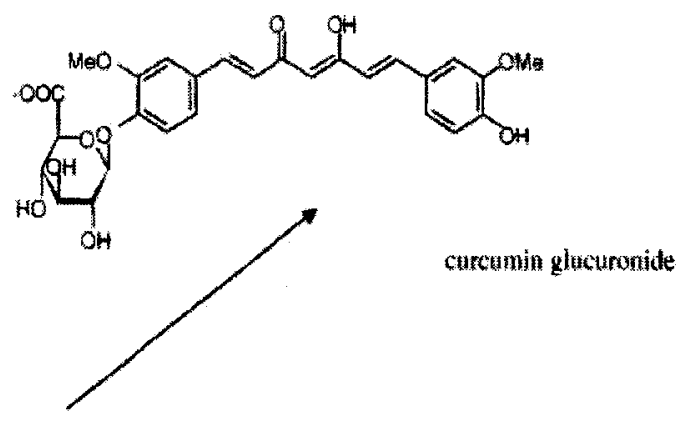<smiles>COc1cc(/C=C/C(=O)/C=C(O)/C=C/c2ccc(O)c(OC)c2)ccc1O</smiles><smiles>CCCCCCCCCCCCCCCCCCCCCCCCCCCCCCCCCCCCC(O)CCc1ccc(O)c(OC)c1</smiles>

Figure 8. Chemical structures of major metabolites of curcumin in rodents and humans. Adapted from "Curcumin: The story so far,"by R.A. Sharma, 2005. European Journal of Cancer, Vol 41:13, p.1955-1968. 
Polasa et al. demonstrated curcumin prevented BPDE-induced strand breaks in peripheral blood lymphocytes [6].

Although curcumin has been shown to inhibit DNA damage [7;83], there is no sound evidence for how curcumin influences p53-mediated cell cycle progression and DNA repair mechanisms in response to BPDE-induced DNA damage. Therefore, the focus of this dissertation is on determining how BPDE-induced DNA damage is affected by p53 expression. Additionally, this dissertation determined how curcumin may play a role in decreasing the carcinogenic activity of BPDE through modulating p53 expression. Thus, modifications of p53 as well as p53-mediated cell cycle arrest and DNA repair mechanisms by curcumin in response to BPDE were examined. It was also determined whether curcumin enhances GST activity as well as GST and GSH levels in a p53dependent manner as an alternative pathway to reduce the carcinogenic effect of BPDE. Overall this work reveals a novel mechanism by which curcumin signals p53-mediated cell cycle arrest and DNA repair mechanisms. 


\section{Objective}

Determine whether pretreatment with curcumin inhibits BPDE-induced DNA damage by lowering the threshold of p53 activation, thereby inducing DNA repair and cell cycle arrest at lower BPDE exposures. To test this hypothesis, human lung cells with and without p53 expression (A549/LXSN and A549/E6) will be used as a model system, to achieve the following aims:

\section{$\underline{\text { Specific Aims }}$}

1. Determine the effects and mechanism of curcumin on the regulation of p53 and its mediation of cell cycle progression in lung cells treated with low dose BPDE.

2. Determine if curcumin modulates the efficiency of DNA repair in a p53-dependent manner.

3. Investigate the role of curcumin in the induction of p53-dependent DNA repair proteins.

4. Determine whether curcumin influences glutathione (GSH) system in a p53dependent manner.

\section{Hypothesis}

Curcumin pretreatment reduces BPDE-induced DNA damage by lowering the threshold of p53 activation and subsequent p53-mediated cell cycle arrest and DNA repair pathways. 


\section{CHAPTER II}

\section{CURCUMIN PRETREATMENT REDUCED BPDE-INDUCED DNA DAMAGE IN A P53- DEPENDENT MANNER}

Introduction

Curcumin (diferuloylmethane) is an active constituent in turmeric derived from the rhizome plant Curcuma longa Linn (Figure 7) [84;85]. Traditionally, curcumin is known for its used in medicine and cooking in the Eastern World. Preclinical studies have shown that curcumin possesses promising activity as a chemopreventive agent against many cancers. It is thought that curcumin blocks tumor initiation and proliferation induced by DNA damaging agents such as bioactivated polycyclic aromatic hydrocarbons (PAHs) $[83 ; 86 ; 87]$.

PAHs are ubiquitous environmental pollutants implicated in lung carcinogenesis (Rubin 2001; Rybicki et al. 2006). PAHs are commonly present in exhaust fumes [8], tobacco smoke [88], barbequed food [20;28], and occupational environments [89]. Benzo(a)pyrene (BaP) is a well known PAH that is metabolized into a number of derivatives. The metabolite $7 R, 8 S$-dihydroxy-9S,10R-epoxy-7,8,9,10tetrahydrobenzo(a)pyrene (BPDE) is defined as the most reactive and ultimate carcinogen formed by BaP bioactivation [90]. BPDE is produced by a series of cyctochrome P450-dependent monoxygenase reactions from BaP (Figure 2) [91]. In the first step, BaP is oxidized primarily by CYP1A1/1B1 to a BaP-7,8-epoxide [92]. Next, epoxide hydrolases catalyze the conversion of the 7,8-epoxide to (+)-BaP-trans-7,8dihydrodiol. Lastly, the (+)-BaP- trans-7,8-dihydrodiol metabolite is further oxidized by 
CYP1A1/1B1 into the ultimate carcinogen BPDE. BPDE is characterized by a bay region which promotes its highly reactive electrophilic activity. BPDE is known to interact with the $\mathrm{N}^{2}$ or $\mathrm{N}^{7}$ position of guanine. When BPDE binds to the $\mathrm{N}^{7}$ position of guanine, very unstable $N^{7}-B P D E-d G$ adducts are produced. As a result, these $N^{7}-B P D E-d G$ adducts are readily hydrolyzed to form apurinic sites. However, BPDE predominantly damages DNA by binding to the $\mathrm{N}^{2}$ position of guanine [93]. If these DNA adducts are not removed, mutations may result which eventually lead to cancer. Efficient detoxification of BPDE and removal of DNA damage are suggested mechanisms which may lead to lower incidence of BPDE-induced mutations [79;94].

Repair of bulky adduct DNA damage mainly occurs through nucleotide excision repair (NER). NER involves five steps: (1) damage recognition, (2) multi-protein excision complex assembly, (3) damage excision, (4) gap filling, and (5) ligation (Figure 6). NER is divided into two distinct subpathways based on how DNA damage is recognized: transcription coupled repair (TCR) or global genomic repair (GGR). TCR specializes in recognizing and eliminating damage on the transcribed strand of active genes. GGR, on the other hand, recognizes and removes damage from the entire genome. GGR is necessary to remove BPDE-DNA adducts [95;96]. A number of studies show that expression of the tumor suppressor protein $\mathrm{p} 53$ is required for the GGR process. Namely, functional p53 is important to mediate the basal and inducible expression of DNA damage recognition proteins XPC and DDB2 (Figure 9) [59;97-99]. Curcumin has been shown to decrease BaP-derived DNA adduct formation as well as induce p53 [100102]. However, it is unclear whether curcumin reduces BPDE-DNA adducts by activating p53-mediated DNA repair mechanisms such as GGR.

Besides the NER pathway removing BPDE-DNA adducts, other mechanisms can prevent BPDE-DNA adducts from forming. Detoxification systems, which inactive BPDE, offer an alternative mechanism against the formation of BPDE-DNA adducts. The 
glutathione (GSH) pathway is the major system which inactivates BPDE [61-63]. The GSH pathway is composed of detoxification enzymes, known as glutathione-Stransferases (GSTs), which catalyze the transfer of GSH to xenobiotic agents like BPDE. As a result, nontoxic, water soluble, inactive compounds are produced and excreted. The GST multi-gene family is made up of seven classes in humans: Alpha, Beta, Zeta, Pi, Theta, Omega, and Mu. Among the seven classes, GST-Mu (GSTM), GST-Alpha (GSTA) and GST-Pi (GSTP) have been proposed as key enzymes for BPDE inactivation [94;103-105]. Contradictory studies have suggested curcumin can induce as well as inhibit GST activity. For example, curcumin was a potent inhibitor of GST activity in 1chloro-2, 4-dintirobenzene (CDNB) treated human melanoma cells [106]. Singh et al. also examined the interaction of GST activity with curcumin [5]. In mice, curcumin decreased $\mathrm{BaP}$-induced forestomach tumorigenesis by significantly increasing hepatic GST activity. In turn, increased GST activity prevents potential interactions of BPDE with DNA. Additionally, GSTs and p53 accumulation are suggested in to protective mechanisms against PAH-induced DNA damage [107-111]. However little is known whether curcumin affects the GSH system in a p53-dependent manner.

In the present study, I investigated whether curcumin reduces BPDE-induced DNA damage in lung epithelial cells by enhancing p53 expression and subsequent p53mediated DNA repair mechanisms. Specifically, I determined the role curcumin plays in the expression of p53 and p53-regulated proteins DDB2 and XPC in response to BPDE. Furthermore, I examined whether curcumin affects BPDE detoxification via the glutathione pathway and whether this effect was p53-dependent. Overall this study provides evidence that curcumin reduces BPDE-DNA adducts in a p53-dependent manner. 


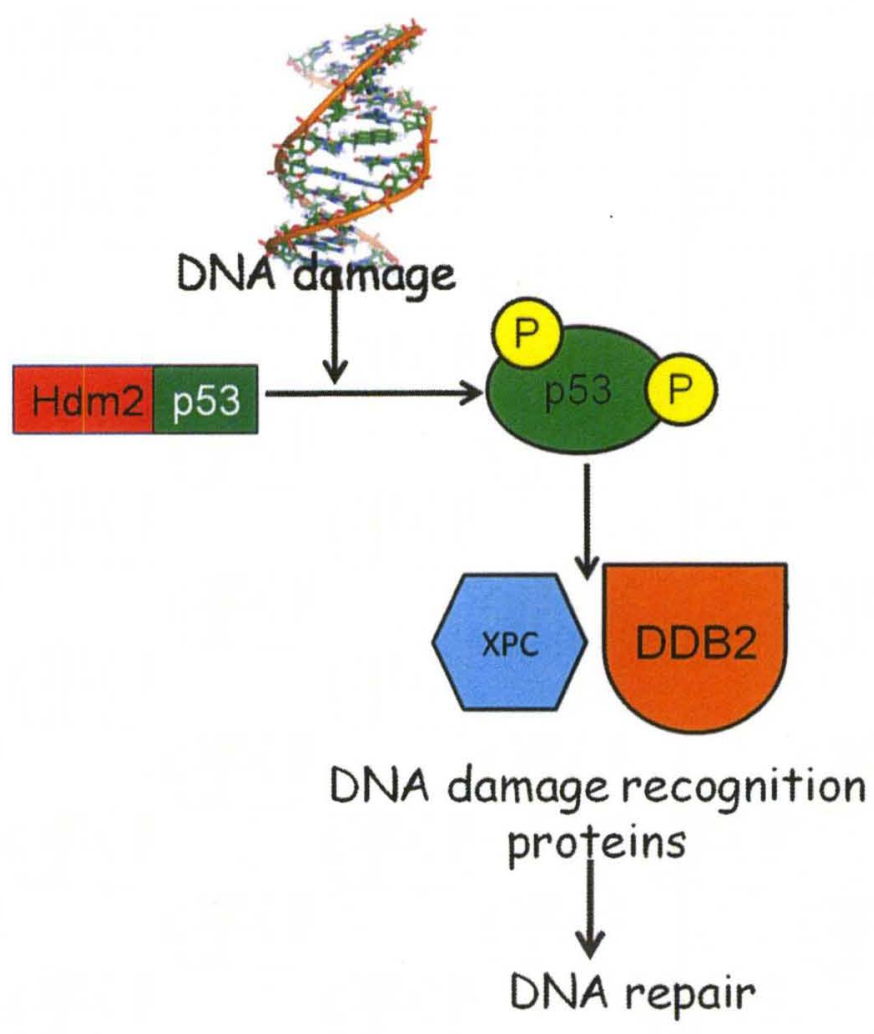

Figure 9. Activated p53 signals the up-regulation of DNA damage recognition proteins $\mathrm{XPC}$ and DDB2 in response to DNA damage. 


\section{Materials and methods}

Cells and Cell cultures

Two isogenic human A549 lung cancer cell lines were used in this study. A549/LXSN (p53+) and A549/E6 (p53-) cells were transduced with either an empty retrovirus (A549/LXSN) or a retrovirus expressing human papillomavirus (HPV)-16 E6 oncoprotein (A549/E6). These cell lines were kind gifts from Dr. Jeffery Schwartz, University of Washington, Seattle, WA. The expression of HPV-16 E6 in A549/E6 cells signals ubiquitin mediated degradation of p53. These cell lines were grown as monolayers in Dulbecco's Modified Eagle's Medium (DMEM): Ham's F12 media supplemented with 1\% Penicillin/Streptomycin (Pen-Strep) (Fisher Scientific, Cat\# ICN1670049), 1\% HEPES (4-(2-hydroxyethyl)-1-piperazineethanesulfonic acid) buffer pH 7.4 (Fisher Scientific, Cat\#ICN1688449), and 10\% fetal bovine serum (FBS) (ThermoFisher Scientific, Cat\# $\mathrm{SH} 30070.01$ ) at $37^{\circ} \mathrm{C}$ in $5 \% \mathrm{CO}_{2}$. HeLa cells, which also express HPV16 E6 oncoprotein, were grown as monolayer in DMEM supplemented with $10 \%$ FBS and $1 \%$ Pen-Strep. HeLa cells were used to confirm the expression of DDB2.

\section{Curcumin treatments}

Curcumin was a kind gift from Dr. Ramesh Gupta, University of Louisville, Louisville, KY. The main stock of curcumin was prepared by dissolution in dimethyl sulfoxide (DMSO; Fisher Scientific, Pittsburg, PA) at $80 \mathrm{mM}$ and stored at $-20^{\circ} \mathrm{C}$. Working stocks were made at $2.5 \mathrm{mM}$ and diluted to $2.5 \mu \mathrm{M}$ in cell culture media. Cell lines were treated with $2.5 \mu \mathrm{M}$ curcumin or DMSO for 24 hours prior to BPDE treatment (Figure 10). 


\section{Plate A549/LXSN (p53+) and A549/E6 (p53-) cells}

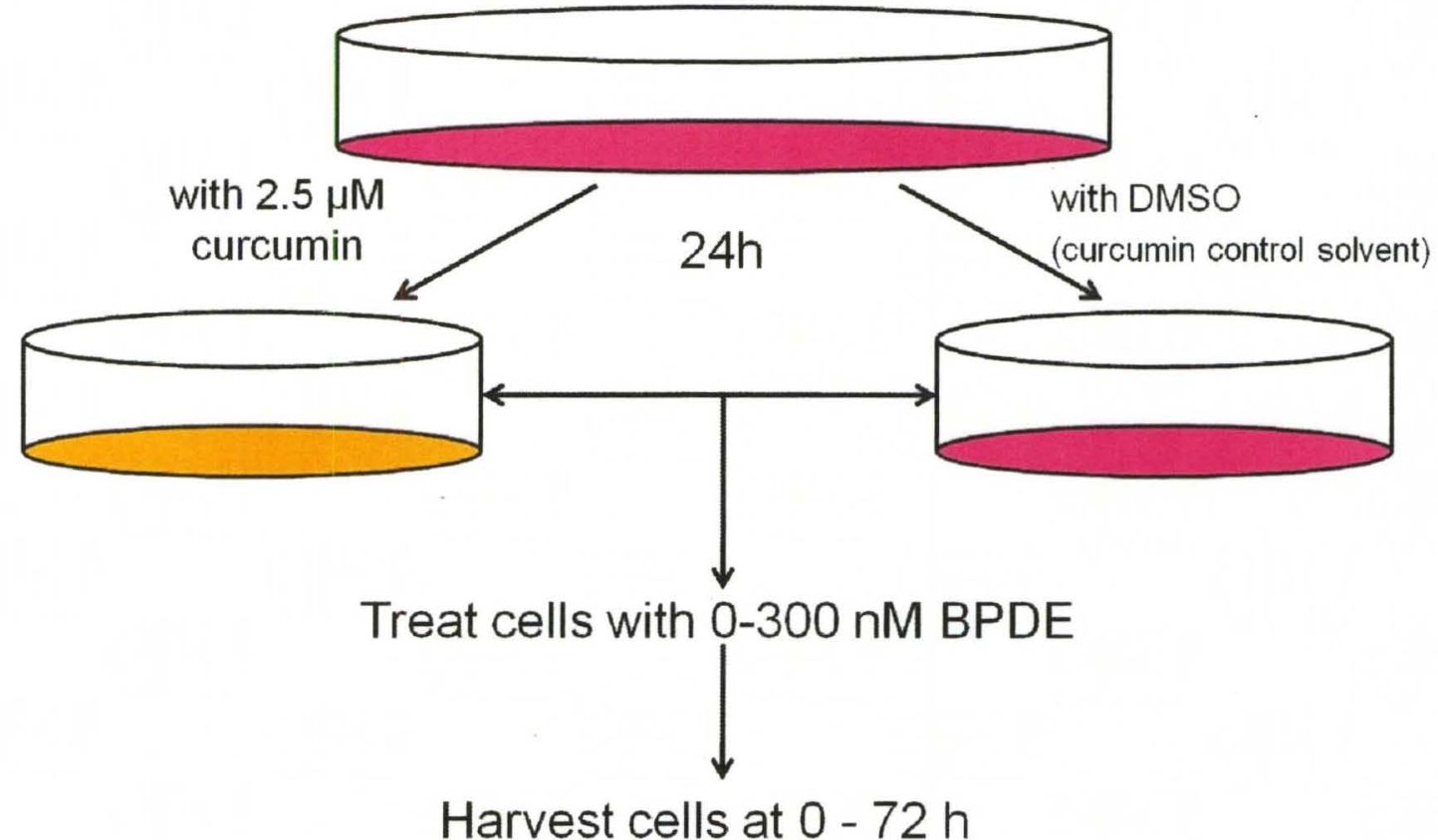

Figure 10. Overall experimental design for all studies. A549/LXSN (p53+) and A549/E6 (p53-) cells were used in this study. A549 cells were plated and incubated for 24 hours at $37^{\circ} \mathrm{C}$ to ensure attachment to plate. The following day, A549 cells were pretreated with 0 (DMSO) or $2.5 \mu \mathrm{M}$ curcumin for 24 hours. Next, the media was removed, and cells were washed twice in PBS. Then cells were refed with fresh media and exposed to 0 (THF), 50, 100 , or $300 \mathrm{nM}$ for $1 \mathrm{~h}$ at $37^{\circ} \mathrm{C}$. After which, cells were washed twice in $1 \mathrm{x}$ PBS and either immediately harvested or refed with fresh media for up to 72 hours. Cells were harvested at different time points for experiments. 


\section{BPDE treatments}

Benzo(a)pyrene- 7R, 8S-dihydrodiol-9S,10R-epoxide ( \pm ), anti (BPDE) was purchased from the National Cancer Institute Chemical Carcinogen Repository (Midwest Research Institute, Kansas City, MO). Tetrahydrofuran (THF; Fisher Scientific, Pittsburg, PA) was used to prepare stocks of BPDE. The main stock was prepared at $10 \mathrm{mM}$ BPDE and stored in a dessicator at $-20^{\circ} \mathrm{C}$. Hydrolysis of BPDE was checked prior to usage [112]. A BPDE mix containing $2 \mu \mathrm{L}$ of $10 \mathrm{mM}$ BPDE, $48 \mu \mathrm{L}$ THF, $50 \mu \mathrm{L} 2$ mercaptoethanol solution (2 mM 2-mercaptoethanol, $0.1 \mathrm{~N} \mathrm{NaOH}$ ), $900 \mu \mathrm{L}$ of double distilled water was prepared to check the fraction of BPDE hydrolyzed. A blank mix was also made which contained $2 \mu \mathrm{L}$ of THF, $50 \mu \mathrm{L}$ of 2-mercaptoethanol solution, and 900 $\mu \mathrm{L}$ of double distilled water. Absorbances at 348 and $343 \mathrm{~nm}\left(\mathrm{~A}_{348}\right.$ and $\mathrm{A}_{343}$, respectively) were collected and the fraction unhydrolyzed was calculated as followed:

Fraction unhydrolyzed $=\left(A_{348} / A_{343}\right) \times 0.529+0.104$

The unhydrolyzed main stock was calculated as the fraction unhydrolyzed against the main stock. Therefore, if the fraction unhydrolyzed was 0.8 , the main stock (10 mM BPDE) was assumed to be $8 \mathrm{mM}$ unhydrolyzed. Working stocks were prepared with fresh THF at concentrations 100 times the desired concentration. Working stocks were diluted to $1 \mathrm{X}$ in cell culture medium. Cells were treated with fresh media containing 50,100 , or $300 \mathrm{nM}$ BPDE. Cells were incubated at $37^{\circ} \mathrm{C}$ for 1 hour and washed twice with calcium-and magnesium-free phosphate-buffered saline $(136 \mathrm{mM} \mathrm{NaCl}, 8.1 \mathrm{mM}$ $\mathrm{Na}_{2} \mathrm{HPO}_{4}, 1.5 \mathrm{mM} \mathrm{KH}_{2} \mathrm{PO}_{4} \mathrm{pH}$ 7.4) (PBS). Cells were either immediately (0 hour) collected or refed with fresh media and incubated at $37^{\circ} \mathrm{C}$ until collection (Figure 10). 


\section{UV treatment}

A549 and HeLa cells were plated in $15 \mathrm{~cm}$ dishes $\left(1 \times 10^{6} \mathrm{cells} / \mathrm{dish}\right)$. Cells were incubated for 16 hours to attach to the plate. Each dish was washed with $5 \mathrm{~mL}$ of PBS and cells overlaid with $2 \mathrm{~mL}$ PBS. Cells were UV-irradiated with 0 or $20 \mathrm{~J} / \mathrm{m}^{2} \mathrm{UVC}$ at a fluence of $0.5 \mathrm{~J} / \mathrm{m}^{2} / \mathrm{s}$. After irradiation, PBS was drained, and the cells refed with 25 $\mathrm{mL}$ of fresh media and incubated until collection.

\section{Cisplatin treatment}

A549 and HeLa cells were seeded in $15 \mathrm{~cm}$ dishes $\left(1 \times 10^{6}\right.$ cells $/$ dish). Cells were incubated overnight to attach to the plate. The next day, stock solutions of cisplatin ( $1 \mathrm{mg} / \mathrm{mL}$ in $1 X$ PBS) were freshly prepared the day of treatment and filter sterilized $(0.22 \mu \mathrm{m})$ prior to use. Cisplatin was dissolved in media to yield a final concentration of 5 $\mu \mathrm{M}$. Cells were washed with $5 \mathrm{~mL}$ of PBS and refed with $25 \mathrm{~mL}$ of media containing cisplatin for 24 hours. After 24 hours, cells were drained of media, washed with $5 \mathrm{~mL}$ PBS, and harvested.

\section{Genomic DNA isolation}

A549 cells were seeded into $15 \mathrm{~cm}$ dishes $\left(1 \times 10^{6} \mathrm{cells} / \mathrm{dish}\right)$ and incubated for 24 hours. The next day cells were treated with or without $2.5 \mu \mathrm{M}$ curcumin for 24 hours. The following day, the media was removed and fresh media added to each dish. Then the cells were treated with 0-300 nM BPDE for 1 hour. BPDE was prepared as described in the "BPDE treatments" section of this chapter. After BPDE exposure, cells were either lysed immediately or refed and incubated 6 or 24 hours. Cells were collected at 0 (immediately after 1 hour BPDE treatment), 6 and 24 hours. During collection, the cells were washed with $5 \mathrm{~mL}$ PBS and lysed with DNA lysis buffer $(0.5 \mathrm{M}$ Tris- $\mathrm{HCl}$ pH $8.0,20$ $\mathrm{mM}$ ethylene diamine tetraacetic acid disodium salt ( $\mathrm{Na}_{2}$ EDTA), $10 \mathrm{mM} \mathrm{NaCl}, 1 \%$ 
sodium dodecyl sulfate (SDS), $0.5 \mathrm{mg} / \mathrm{mL}$ proteinase $\mathrm{K}$ ). Lysates were incubated overnight at $37^{\circ} \mathrm{C}$ for proteinase $\mathrm{K}$ digestion. Lysates were mixed with $1 / 4$ volume saturated $\mathrm{NaCl}$ solution and centrifuged ( 30 minutes, $500 \times \mathrm{g}$, room temperature) to pellet undigested protein, cellular debris and SDS precipitate. Supernatants were collected in a fresh tube, mixed with 2 volumes $96 \%$ ethanol, and inverted several times. Precipitated nucleic acids were collected on a glass hook, rinsed in $70 \%$ ethanol, briefly dried to remove excess ethanol, and resuspended in $1 \mathrm{X}$ Tris-EDTA (TE) buffer (10 mM Tris- $\mathrm{HCl} \mathrm{pH} \mathrm{7.4,} 1 \mathrm{mM} \mathrm{Na}{ }_{2}$ EDTA). RNA was digested by the addition of fresh $100 \mu \mathrm{g} / \mathrm{mL}$ heat-treated RNase $A(40 \mathrm{mg} / \mathrm{mL})$ and incubation at $37^{\circ} \mathrm{C}$ for 3 hours. The solution was then mixed gently with $1 / 5$ volume $11 \mathrm{M}$ ammonium acetate $(\mathrm{pH} 6.7)$ and 2 volumes cold $96 \%$ ethanol. DNA precipitated overnight and was recovered the following day. Next, the DNA was rinsed in $70 \%$ ethanol, briefly dried, and resuspended in $1 \times$ TE buffer. DNA was quantified by $A_{260}$ and purity determined by $A_{260} / A_{280}$ ratio. DNA was stored at $-20{ }^{\circ} \mathrm{C}$ until ready for use.

\section{DNA adduct determination by immunoslot blot assay}

BPDE-DNA adducts were determined using the method of Venkatachalam et al. [79]. Briefly 6 or $0.75 \mu \mathrm{g}$ of A549/LXSN or A549/E6 genomic DNA, respectively was bound to nitrocellulose BA 85 membrane (Schleicher and Schuell, Keene, NH) using a Minifold II slot blot apparatus (Schleicher and Schuell, Keene, NH). BPDE-DNA adducts were detected using BP1 primary antibody developed against anti-BPDE modified DNA (a kind gift from Altaf A. Wani, Ohio State University, Columbus, $O H)(1: 2000)$ followed by goat anti-rabbit IgG alkaline phosphatase (AP)-labeled secondary antibody $(1: 10,000)$ (Zymed). Signal intensities were visualized using enhanced chemifluorescence substrate (ECF, GE Healthcare, Piscataway, NJ). The intensity of each band was determined using a Molecular Dynamics Storm 860 (Minneapolis, MN) in blue fluorescence mode, 
and quantitated by ImageQuant software. BPDE-DNA adduct levels and the rates of repair were calculated by comparing the band intensities of DNA from BPDE treated cells against DNA from untreated samples and normalized to values to 0 hour samples.

\section{Western blot analysis}

A549 cells were seeded into $10 \mathrm{~cm}$ dishes $(750,000 \mathrm{cells} / \mathrm{dish})$ and incubated for 24 hours to attach to the dish. The cells were treated with or without $2.5 \mu \mathrm{M}$ curcumin for 24 hours. The following day, the cells were treated with 0-300 nM BPDE for 1 hour after aspirating the media and washing with $1 \mathrm{~mL}$ PBS. After BPDE exposure, cells were either lysed immediately or refed and incubated 24 hours. During collection, total protein lysates from whole cells were prepared after BPDE treatment with protein lysis buffer solution (10 mM Tris-HCl pH 7.4, $1 \mathrm{mM} \mathrm{Na}{ }_{2}$ EDTA $0.1 \%$ SDS, $0.18 \mathrm{mg} / \mathrm{mL}$ phenylmethylsulphonylfluoride (PMSF)). The lysates were incubated at $37^{\circ} \mathrm{C}$ for 5 minutes. The lysates were sonicated (to make the lysates less viscous) and centrifuged at $13,000 \times g$ for 30 minutes, $4^{\circ} \mathrm{C}$ to precipitate cell debris. Total protein content from supernatants was determined by Bradford assay (Biorad, Hercules, CA) using bovine serum albumin (BSA) as a standard. Samples were denatured with loading buffer (50 $\mathrm{mM}$ Tris- $\mathrm{HCl} \mathrm{pH} \mathrm{6.8,} \mathrm{10 \%} \mathrm{glycerol,} \mathrm{2 \%} \mathrm{SDS,} \mathrm{1 \%} \mathrm{2-mercaptoethanol,} 12.5 \mathrm{mM}$ $\mathrm{Na}_{2}$ EDTA, $0.02 \%$ bromophenol blue) and heated at $90^{\circ} \mathrm{C}$ for 2 minutes. Twenty micrograms of total cellular protein were resolved by electrophoresis in a $10 \%$ SDSpolyacrylamide gel with a $1 \mathrm{~cm}$ stacking gel at $120 \mathrm{~V}$ for about 1.5 hours. Proteins were electro-transferred to a nitrocellulose membrane $\left(100 \mathrm{~V}, 1\right.$ hour, $\left.4^{\circ} \mathrm{C}\right)$. Nitrocellulose membranes were stained with $1 \mathrm{X}$ Ponceau S stain (Fisher Scientific, Pittsburg, PA) for 10 minutes to ensure complete electro-transfer, adequate separation of proteins, and equal protein load. After a digital photograph (Kodak Photography) was taken of the Ponceau stained membrane, the membrane was destained for 5 minutes in Tris-buffered 
saline Tween-20 (100 mM Tris- $\mathrm{HCl} \mathrm{pH} \mathrm{7.5,} 150 \mathrm{mM} \mathrm{NaCl}, 0.1 \%$ Tween 20) (TBST) and blocked with $5 \%$ milk (Nestlé, Solon, $\mathrm{OH}$ ) in TBST for 1 hour at room temperature. Membranes were incubated with the following primary antibodies and dilutions as described by the manufacturer: anti-p53 DO-1mouse monoclonal antibody (NeoMarkers, Cat\# MS-187-P) (1:1000); anti-phospho-p53 Ser15 mouse polyclonal antibody (Cell Signaling Technology, Cat\#9284) (1:500); anti-DDB2 mouse monoclonal antibody (Abcam, Cat\# 2246C4a) (1:50); anti-XPC mouse monoclonal antibody (Santa Cruz, Cat\#sc-30156, St. Louis, MO) (1:1000); anti-GSTP goat polyclonal antibody (Detroit R\&D, Cat\# GST ANTIR3 , Detroit, MI) (1:10,000); anti-GSTA goat polyclonal antibody (Detroit R\&D, Cat\# GST ANTI 1, Detroit, MI) (1:10,000); anti-GSTM goat polyclonal antibody (Detroit R\&D, Cat\# GST ANTI 2 , Detroit, MI) (1:10,000); GAPDH (Abcam, Cat\# ab9484) (1:10.000) or $\beta$-actin (Abcam, Cat\# ab8227) $(1: 10,000)$ served as the loading controls and $\beta$-actin mouse monoclonal antibody (Abcam, Cat\# 8227) $(1: 10,000)$. The membranes were washed with TBST three times for 10 minutes each. Detection of GAPDH and $\beta$-actin served as loading control. Blots probed with anti-p53, anti-phospho-p53 Ser 15, anti-DDB2, anti-XPC, and anti- $\beta$-actin primary antibodies were incubated with rabbit anti-mouse IgG conjugated to horseradish peroxidase (HRP) (Cell Signaling Technologies, Cat \#7076) (1:2,000 in 5\% milk in TBST) for detection. AntiGSTP primary antibody was detected by goat anti-rabbit IgG conjugated to HRP (Cell Signaling Technologies, Cat \#7074) (1:10,000 in 5\% milk in TBST). Signal intensities were visualized using enhanced chemiluminescence substrate plus (ECL plus, GE Healthcare, Piscataway, NJ, Cat\#RPN2132). Detection and quantitation of signal intensities was achieved using a Molecular Dynamics Storm 860 in blue fluorescence mode. Signal intensities were analyzed by ImageQuant. 


\section{GST colorimetric assay}

A549 cells were seeded into $10 \mathrm{~cm}$ dishes $(750,000$ cells/dish) and incubated for 24 hours. The cells were treated with or without $2.5 \mu \mathrm{M}$ curcumin for 24 hours. The following day, the cells were exposed to 0-300 nM BPDE for 1 hour after removing the media and washing with $1 \mathrm{~mL}$ PBS. Whole cells were immediately scraped in cold phosphate-buffer solution ( $25 \mathrm{mM}$ sucrose, $50 \mathrm{mM}$ potassium phosphate, $1 \mathrm{mM}$ $\mathrm{Na}_{2}$ EDTA, $\mathrm{pH}$ 6.5) after BPDE treatment. Cells were sonicated on ice and centrifuged at $14,000 \mathrm{rpm}$ for 30 minutes, $4^{\circ} \mathrm{C}$. Supernatants were collected and stored at $-80^{\circ} \mathrm{C}$ up to a month. Total protein content from supernatants was determined by Bradford assay using BSA as a standard. Supernatants $(25-50 \mu \mathrm{g}$ of protein) were mixed with $100 \mu \mathrm{L}$ of 10 mM L-glutathione (GSH; Sigma Aldrich, St. Louis, MO) in phosphate-buffer solution (pH 6.5) in a cuvette. Enough phosphate-buffer solution was added to bring the final volume in the cuvette up to $1 \mathrm{~mL}$. Absorbance was read at $340 \mathrm{~nm}$ for $1 \mathrm{~min}$ in a Varian Cary UV Spectrophotometer (Agilent Technologies, Palo Alto, CA) to determine background activity. Ten microliters of 1-chloro-2,4-dintrobenzene (CDNB, Cat\# 237329, Santa Cruz, St. Louis, MO) in ethanol was added and absorbance read for an additional 3 minutes to gather enzyme kinetics data. GST activity was calculated using the following formula:

\section{$[\Delta \mathrm{Abs} / \mathrm{min}$ (sample) - $\Delta \mathrm{Abs} / \mathrm{min}$ (background)] \\ $A^{m} \times m g$ protein added}

where $A^{m}$, the extinction coefficient for GS-DNB, equals $0.0096 \mu \mathrm{mol}^{-1} \mathrm{~cm}^{-1}$. GST activity is expressed as nanomoles per minute per microgram of protein ( $\mathrm{nmol} / \mathrm{min} / \mu \mathrm{g}$ protein). GST activity was normalized to A549/E6 cells treated only with BPDE. 


\section{Cellular GSH content}

A549 cells were seeded into $10 \mathrm{~cm}$ dishes $\left(7.5 \times 10^{5} \mathrm{cells} / \mathrm{dish}\right)$ and incubated for 24 hours. The cells were treated with or without $2.5 \mu \mathrm{M}$ curcumin for 24 hours. Curcumin at $2.5 \mu \mathrm{M}$ was prepared as described above. The following day, the cells were exposed to 0-300 nM BPDE for 1 hour after removing the media and washing with $1 \mathrm{~mL}$ PBS. BPDE was prepared as described above. Whole cells were harvested by scraping in 1 $\mathrm{mL}$ cold PBS, collected into pre-chilled microfuge tubes, and centrifuged ( $1000 \times \mathrm{g}, 5$ minutes, $\left.4^{\circ} \mathrm{C}\right)$. Pellets were resuspended in $1 \mathrm{~mL}$ fresh ice-cold extraction buffer $(0.1 \%$ Triton, $0.6 \%$ sulfosalicylic acid in $0.1 \mathrm{M}$ potassium phosphate with $10 \mathrm{mM} \mathrm{Na}{ }_{2} \mathrm{EDTA}, \mathrm{pH}$ 7.5), sonicated on ice 2-3 minutes, and freeze-thawed twice. After the second freezethaw cycle, cells were centrifuged ( $3000 \times \mathrm{g}, 4$ minutes, $\left.4^{\circ} \mathrm{C}\right)$ and supernatant collected into microfuge tubes. Pellets were dissolved in $0.2 \mathrm{M} \mathrm{NaOH}$ and total protein content from this solution was determined by Bradford assay using BSA as a standard.

Samples were assayed for glutathione using L-glutathione (Sigma-Aldrich, St. Louis, MO) as a standard [113]. A fresh $0.1 \mathrm{M}$ potassium phosphate stock solution (KPE) was prepared by mixing $16 \mathrm{~mL}$ of solution $A$ with $84 \mathrm{~mL}$ of solution $B$ (solution $A$ :

Add $3.4 \mathrm{~g} \mathrm{KH}_{2} \mathrm{PO}_{4}$ to $250 \mathrm{~mL} \mathrm{dH}{ }_{2} \mathrm{O}$; solution B: $8.5 \mathrm{~g} \mathrm{~K}_{2} \mathrm{HPO}_{4}$ to $500 \mathrm{~mL} \mathrm{dH}_{2} \mathrm{O}$ ). A $0.1 \mathrm{M}$ phosphate-EDTA (KPE) buffer was prepared by adjusting the $0.1 \mathrm{M}$ potassium phosphate stock solution to $\mathrm{pH} 7.5$ and adding $0.327 \mathrm{~g} \mathrm{Na}_{2}$ EDTA was added. Next, a GSH stock solution was prepared by dissolving $1 \mathrm{mg}$ of GSH in $1 \mathrm{~mL} \mathrm{KPE}$. The GSH stock solution was diluted $1: 100$ to make a $10 \mu \mathrm{g} / \mathrm{mL}$ working solution. Then a 26.4 $\mathrm{nM} / \mathrm{mL}$ GSH standard solution was prepared by mixing $800 \mu \mathrm{L}$ of GSH working solution with $200 \mu \mathrm{L}$ of $\mathrm{KPE}$. The $26.4 \mathrm{nM} / \mathrm{mL}$ solution served as the highest GSH standard solution. Twofold serial dilutions were prepared until a $0.413 \mathrm{nM} / \mathrm{mL}$ GSH standard solution was achieved. GSH standards were kept on ice. DTNB (1.68 mM), $\beta-N A D P H$ $(0.79 \mathrm{mM})$, and Glutathione reductase (GR) $(6.68 \mathrm{U} / \mathrm{mL})$ solutions were also prepared by 
dissolving compound in KPE. To assay, $20 \mu \mathrm{L}$ of each standard and each sample in triplicate were added to a microtiter plate at room temperature. Equal volumes of DTNB and GR solutions were mixed together (DTNB:GR). Then, $120 \mu \mathrm{L}$ of the DTNB:GR solution was added to each well of the plate. The plate sat for about 30 seconds to allow the DNTB/GR solution to convert all GSSG in my samples to GSH. Sixty microliters of $\beta$ NADPH was added to each well of the plate. An absorbance at $412 \mathrm{~nm}$ for the samples was read immediately at $15-30$ intervals for 5 minutes. The total GSH concentration of my samples was determined by the GSH standard curve. GSH was expressed as nanomoles per milligram total cellular protein ( $\mathrm{nmol} / \mathrm{min} / \mu \mathrm{g}$ of protein). Samples were normalized to A549/E6 cells treated with respective concentrations of BPDE only.

\section{Statistical analysis}

All statistical analysis was measured using GraphPad Prizm (version 5.01). All data are expressed as means \pm standard deviations (STDEV) of at least three independent experiments. BPDE-DNA adducts immediately after 1 hour BPDE treatment, XPC, DDB2, GSTP protein levels, GST activity, and GSH levels were analyzed by one-way analysis of variance (ANOVA) followed by Bonferroni's comparison test. Analysis of the overall repair rate was analyzed by two-way ANOVA. $p<0.05$ was considered statistically significant. 
Results

\section{Curcumin pretreatment significantly lowers BPDE-induced DNA damage in p53- expressing cells}

BPDE attaches to guanine bases of DNA to cause damage. P53 accumulates in response to DNA damage. Separate studies show that curcumin inhibits chemicalinduced damage and up-regulates p53 [7;85;114-116]. It is, however, unclear whether curcumin prevents BPDE-induced DNA damage by modulating p53 expression. Immunoslot blot assay was used to determine the effect of curcumin on BPDE-DNA adduct levels in isogenic cells expressing and not expressing p53 (Figure 11). A549/LXSN (p53+) and A549/E6 (p53-) cells were incubated with or without curcumin for 24 hours, followed by 50,100 , or $300 \mathrm{nM}$ BPDE. Cells were immediately harvested and lysed after 1 hour BPDE treatment. Relative BPDE-DNA adducts were assessed and compared on separate membranes based on BPDE concentration used. BPDE-DNA adduct levels were significantly lower in LXSN than E6 cells at all three BPDE exposures (Figure 11). Furthermore, curcumin pretreatment significantly lowered BPDE-DNA adduct levels in LXSN cells at all BPDE exposures. Curcumin pretreatment did not affect BPDE-DNA adduct levels in E6 cells. Thus these results show that curcumin reduces BPDE-DNA adducts in a p53-dependent manner.

\section{XPC and DDB2 are not regulated by p53-expression in A549 cells}

Bulky helix distorting DNA lesions induced by BPDE are removed by the GGR system [117]. DNA damage recognition proteins XPC and DDB2 function in the GGR system to recognize bulky DNA adducts $[96 ; 118]$. It is well established that basal and inducible expression of XPC and DDB2 are regulated by p53 [59;119]. Little is known about whether curcumin affects the expression of XPC and DDB2. I therefore used 


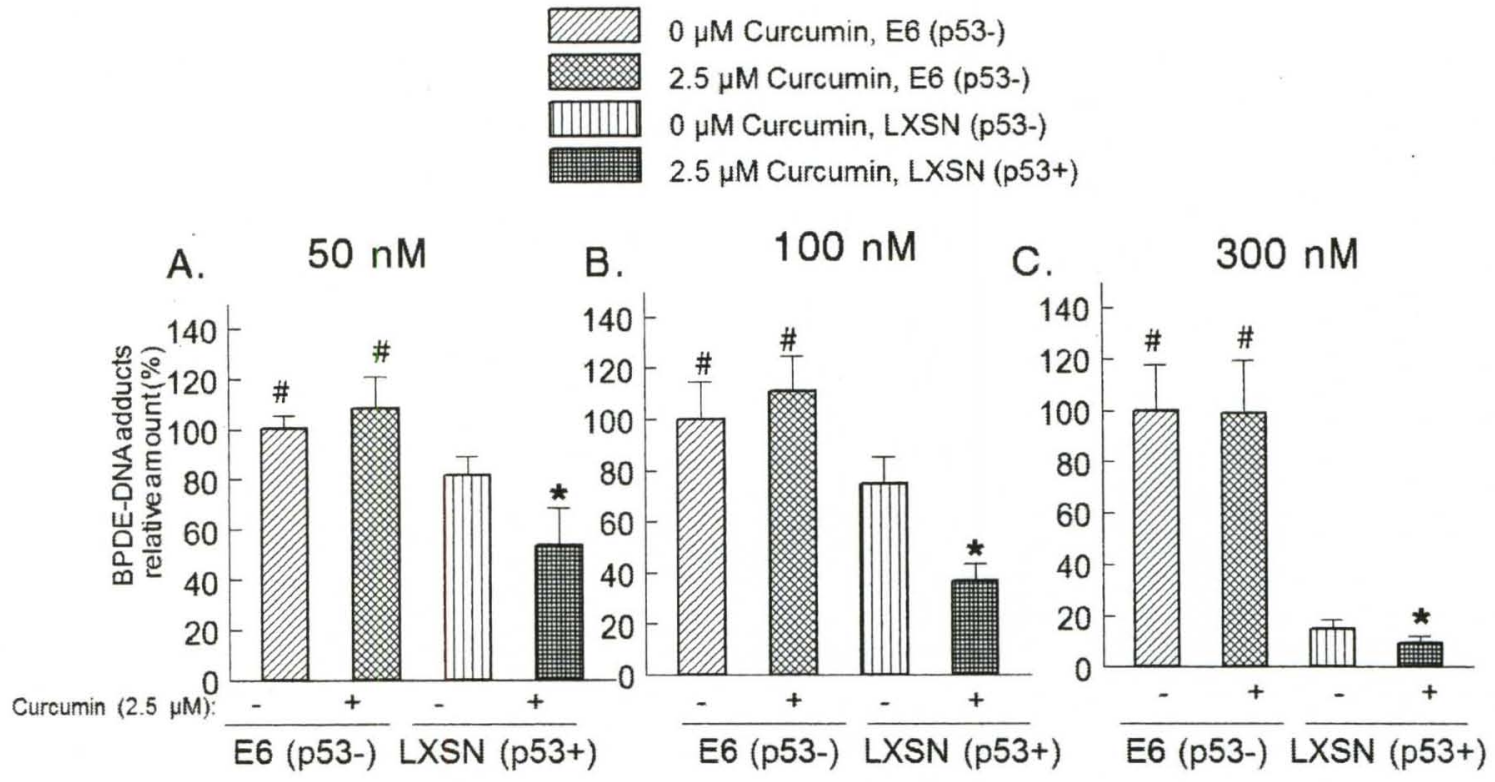

Figure 11. Immunoslot blot analysis of BPDE-DNA adducts immediately after 1 hour BPDE treatment. A549/LXSN (p53+) cells and A549/E6 (p53-) were treated with DMSO $(0 \mu \mathrm{M})$ or $2.5 \mu \mathrm{M}$ curcumin for $24 \mathrm{~h}$ followed by $50(\mathrm{~A}), 100(\mathrm{~B})$, or $300 \mathrm{nM}$ BPDE (C) for 1 hour. Cells were harvested immediately after BPDE exposure. Genomic DNA was collected and BPDE-DNA adduct levels determined by immunoslot blot assay. The difference between DNA from BPDE treated cells and DNA untreated cells were calculated. The values from triplicate samples were averaged and normalized to BPDEDNA adducts in A549/E6 cells with respective BPDE only treatments ( $0 \mu \mathrm{M}$ curcumin). Data are presented as mean \pm STDEV of BPDE-DNA adducts in three independent experiments. Analysis of data was performed using a one-way ANOVA followed by Bonferroni's comparison test. \#P<0.05 vs. $\mathrm{LXSN}$ cells with corresponding curcumin and BPDE treatment. * $\mathrm{P}<0.05$ compares $\mathrm{LXSN}$ cells treated with BPDE alone against curcumin pretreated LXSN cells exposed to respective BPDE. 
Western blot analysis to investigate how curcumin affects $p 53$ as well as p53-regulated DNA damage recognition proteins XPC and DDB2 (Figures 12 through 15). In Figures 12 and 14, A549 cells were pretreated with or without curcumin for 24 hours, and then exposed to $0,50,100$, or $300 \mathrm{nM}$ BPDE for 1 hour. Protein extracts were collected from lysed cells either immediately $(0 \mathrm{~h})$ or 24 hours after BPDE treatment. P53 was present in LXSN (p53+), but not E6 (p53-) cells (Figures 12 and 14). P53 was increased 24 hours after BPDE treatment only in A549/LXSN cells. Curcumin pretreatment further increased p53 in p53+ cells. XPC was present in both cell lines (Figure 12). However, the level of XPC differed depending on curcumin pretreatment, p53 expression, and time. Overall, XPC was higher in A549/LXSN cells (Figure 12A) than A549/E6 cells (Figure 12B). XPC was not induced immediately after 1 hour BPDE exposure in either cell line. XPC was increased in a concentration-dependent manner 24 hours after BPDE treatment in p53+ cells (Figure 12A). Yet, XPC was absent 24 hours with or without BPDE treatment in p53- cells (Figure 12B). Curcumin pretreatment further increased XPC in A549/LXSN cells. Curcumin pretreatment also increased XPC levels in A549/E6 immediately after 1 hour BPDE treatment. Therefore these results indicate that XPC is not regulated by $\mathrm{p} 53$ expression in A549 cells. Curcumin pretreatment however changes the expression of XPC in response to BPDE-induced DNA damage.

DDB2 was also present in both cell lines; however neither curcumin nor BPDE changed DDB2 levels (Figure 14 and 15). To investigate further whether DDB2 is regulated by p53, DDB2 was examined after DNA damage in different cell types with different DNA damaging agents (Figure 14). A549/LXSN (p53+), A549/E6 (p53-), and HeLa cells were exposed to either $300 \mathrm{nM}$ BPDE for 1 hour (BPDE), UV $\left(20 \mathrm{~J} / \mathrm{m}^{2}\right)(U V)$, or $5 \mu \mathrm{M}$ cisplatin 
A

A549/LXSN (p53+)

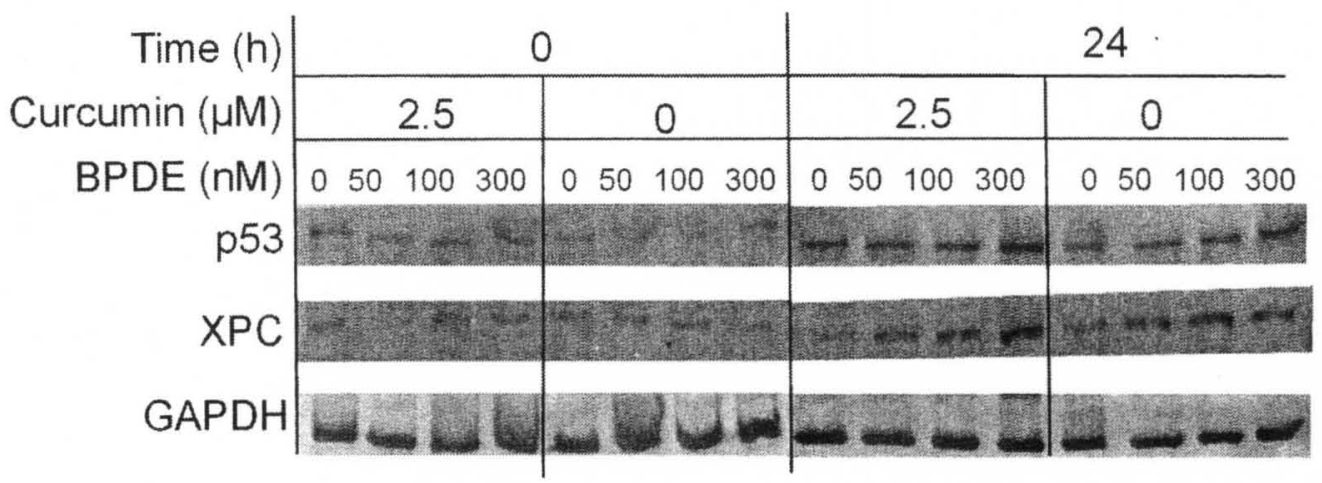

B

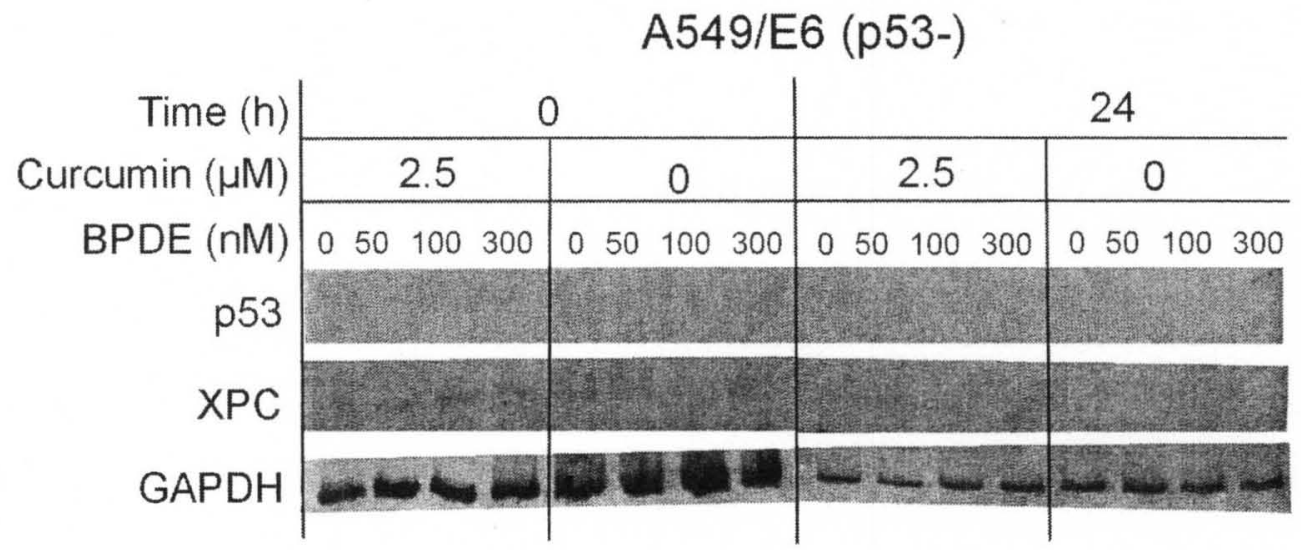

Figure 12. Western blot analysis of p53 and XPC immediately $(0 \mathrm{~h})$ and $24 \mathrm{~h}$ after BPDE treatment. A549/LXSN (p53+) (A) and A549/E6 (B) cells were incubated with 0 or $2.5 \mu \mathrm{M}$ curcumin for $24 \mathrm{~h}$. Cells were then exposed to $0,50,100$ or $300 \mathrm{nM}$ BPDE for 1 hour and washed twice with $\mathrm{Ca}^{2+}-/ \mathrm{Mg}^{2+}$-free PBS. Next, cells were either immediately harvested $(0 \mathrm{~h})$ or incubated at $37^{\circ} \mathrm{C}$ for $24 \mathrm{~h}$ in fresh media, and then harvested. Whole cell lysates were collected from harvested cells. Twenty micrograms of protein were resolved on $10 \%$ SDS-PAGE for Western blot analysis. GAPDH served as loading control. Data shown are representative of three independent experiments. 


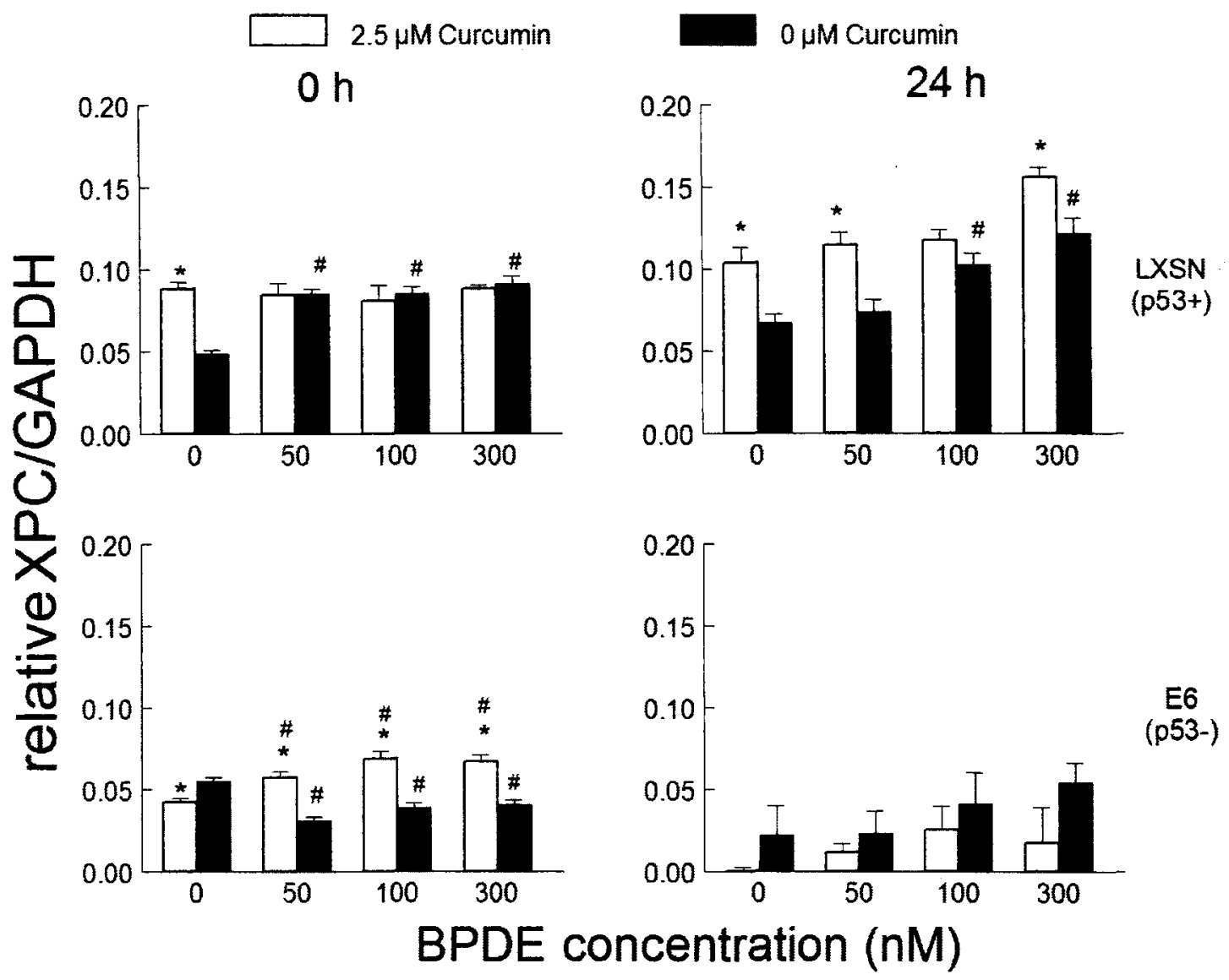

Figure 13. Relative XPC levels immediately $(0 \mathrm{~h})$ and $24 \mathrm{~h}$ after BPDE treatment. A549/LXSN (p53+) (top panels) and A549/E6 (bottom panels) cells were incubated with 0 or $2.5 \mu \mathrm{M}$ curcumin for $24 \mathrm{~h}$. Cells were then exposed to $0,50,100$ or $300 \mathrm{nM}$ BPDE for 1 hour and washed twice with $\mathrm{Ca}^{2+}-\mathrm{Mg}^{2+}$-free PBS. Next, cells were either immediately harvested $(0 \mathrm{~h})$ or incubated at $37^{\circ} \mathrm{C}$ for $24 \mathrm{~h}$ in fresh media, and then harvested. Whole cell lysates were collected from harvested cells. Twenty micrograms of protein were resolved on $10 \%$ SDS-PAGE for Western blot analysis. The ratio between XPC and GAPDH was computed from Western Blots. Analysis of data was performed using a one-way ANOVA followed by Bonferroni's comparison test. ${ }^{*} \mathrm{P}<0.05$ compared to $0 \mu \mathrm{M}$ curcumin. \#P<0.05 compared to $0 \mathrm{nM}$ BPDE. 
A

A549/LXSN (p53+)

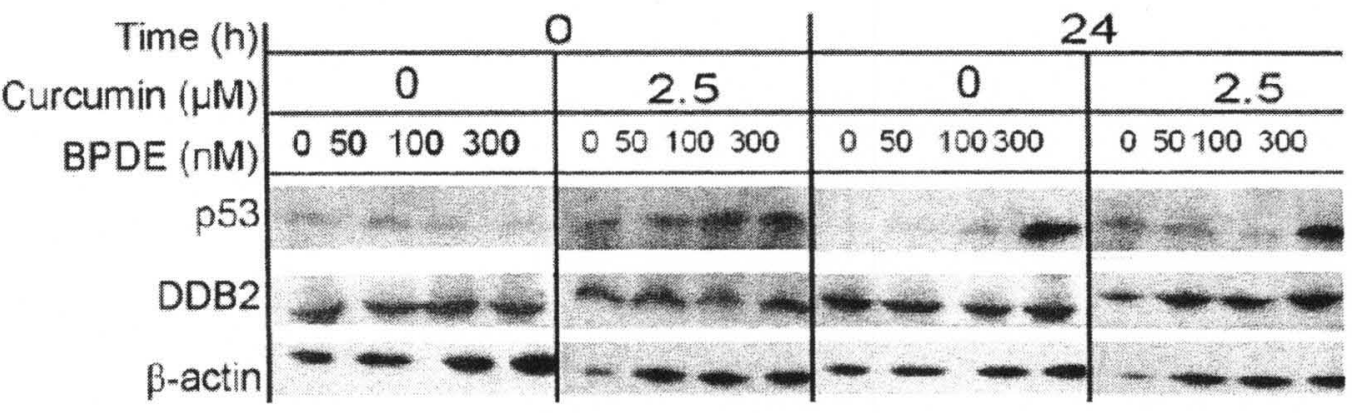

B

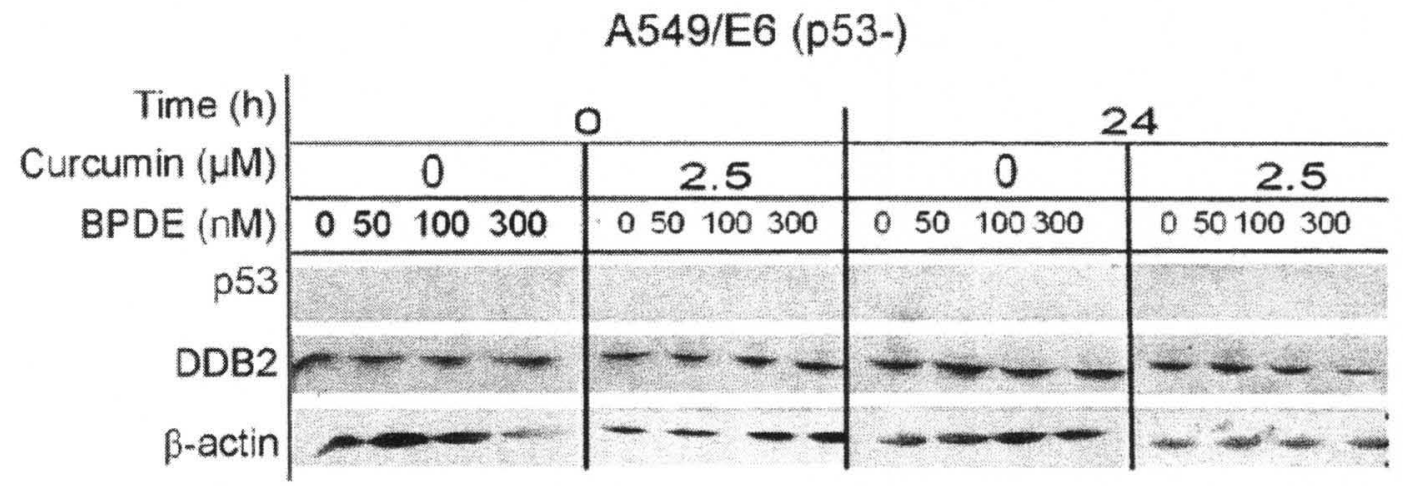

Figure 14. Western blot analysis of p53 and DDB2 levels immediately $(0 h)$ and $24 \mathrm{~h}$ after BPDE treatment. A549/LXSN (p53+) (A) and A549/E6 (B) cells were incubated with 0 or $2.5 \mu \mathrm{M}$ curcumin for $24 \mathrm{~h}$. Cells were then exposed to $0,50,100$ or $300 \mathrm{nM}$ BPDE for 1 hour and washed twice with $\mathrm{Ca}^{2+}-\mathrm{Mg}^{2+}$-free PBS. Next, cells were either immediately harvested $(0 \mathrm{~h})$ or incubated at $37^{\circ} \mathrm{C}$ for $24 \mathrm{~h}$ in fresh media, and then harvested. Whole cell lysates were collected from harvested cells. Twenty micrograms of protein were resolved on $10 \%$ SDS-PAGE for Western blot analysis. $\beta$-actin served as loading control. Data shown are representative of three independent experiments. 


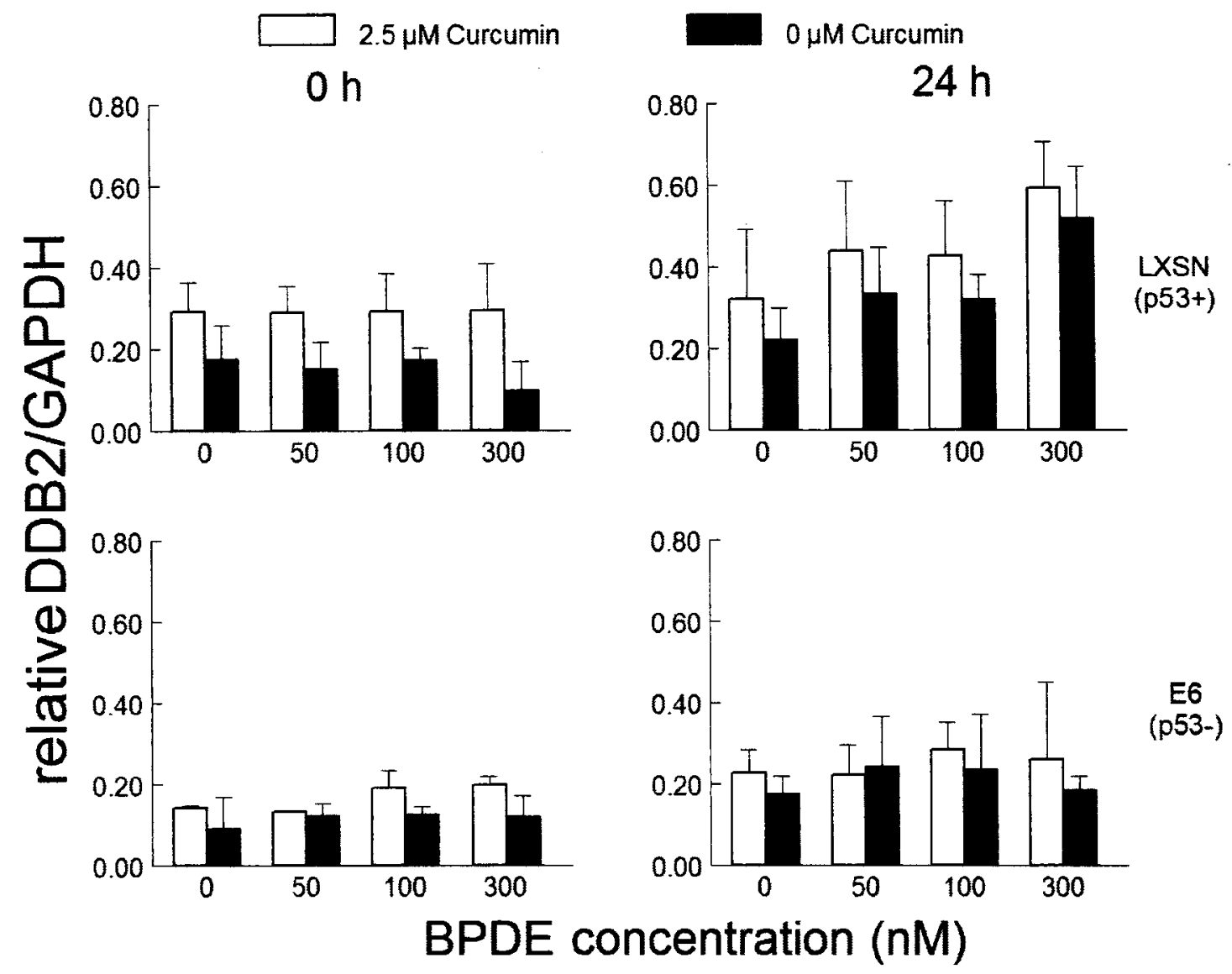

Figure 15. Relative DDB2 levels immediately $(0 \mathrm{~h})$ and $24 \mathrm{~h}$ after BPDE treatment. A549/LXSN (p53+) (top panles) and A549/E6 (bottom panels) cells were incubated with 0 or $2.5 \mu \mathrm{M}$ curcumin for $24 \mathrm{~h}$. Cells were then exposed to $0,50,100$ or $300 \mathrm{nM}$ BPDE for 1 hour and washed twice with $\mathrm{Ca}^{2+}-\mathrm{Mg}^{2+}$-free PBS. Next, cells were either immediately harvested $(0 \mathrm{~h})$ or incubated at $37^{\circ} \mathrm{C}$ for $24 \mathrm{~h}$ in fresh media, and then harvested. Whole cell lysates were collected from harvested cells. Twenty micrograms of protein were resolved on $10 \%$ SDS-PAGE for Western blot analysis. The ratio between XPC and GAPDH was computed from Western Blots. Analysis of data was performed using a one-way ANOVA followed by Bonferroni's comparison test. 


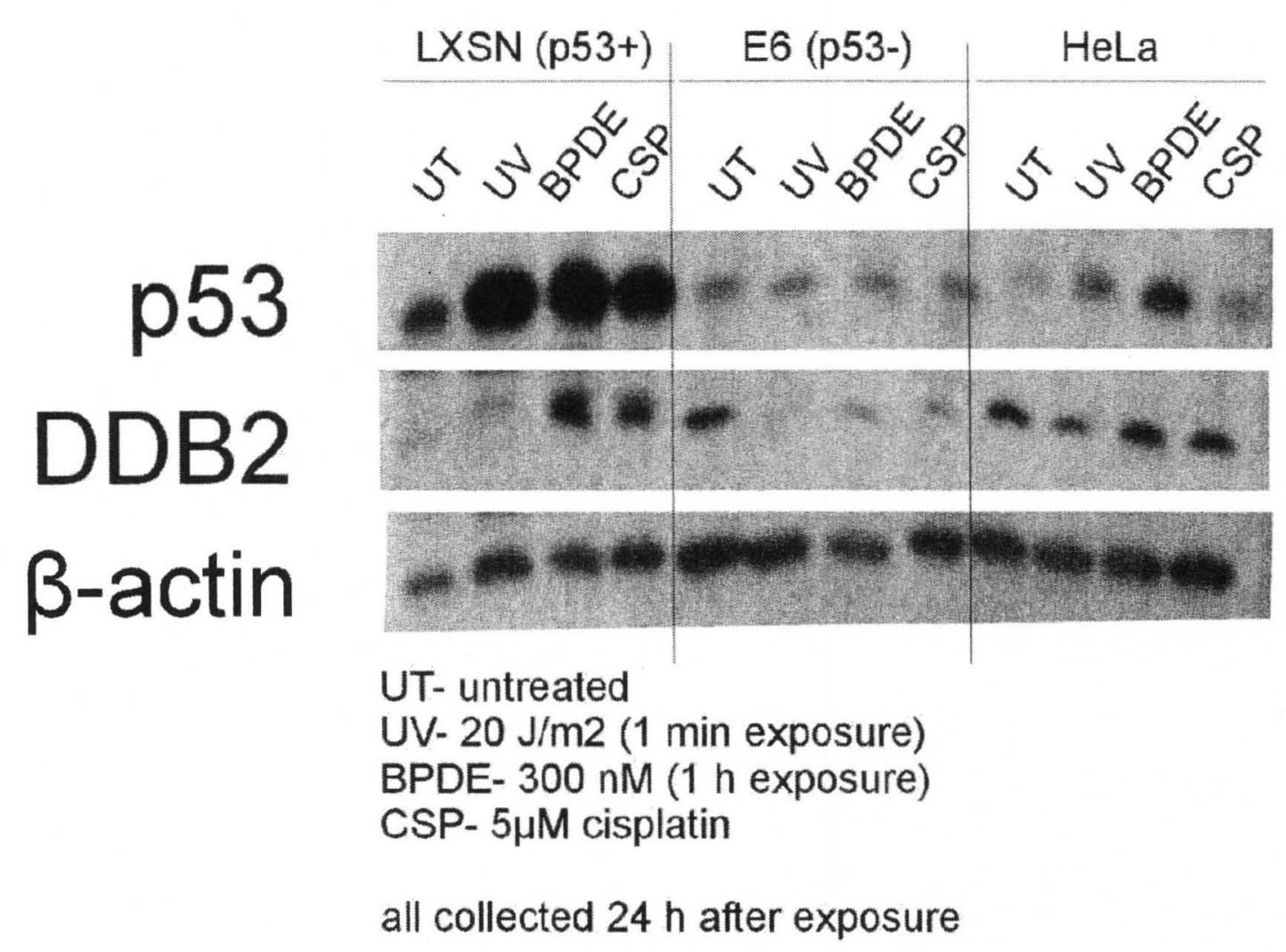

Figure 16. Western blot analysis of p53 and DDB2 levels 24 hours after DNA damage in different cell types with different treatments. A549/LXSN (p53+), A549/E6 (p53-), and HeLa cells were exposed to either $300 \mathrm{nM}$ BPDE for 1 hour (BPDE), UV (20 J/m²) (UV), or $5 \mu \mathrm{M}$ cisplatin (CSP) for 24 hours. Cells were then washed twice with $\mathrm{Ca}^{2+}-\mathrm{Mg}^{2+}$-free PBS after treatments and incubated at $37^{\circ} \mathrm{C}$ for an additional 24 hours in fresh media. Whole cell lysates were collected from harvested cells after 24 hours. Twenty micrograms of protein were resolved on $10 \%$ SDS-PAGE for Western blot analysis. $\beta$ actin serves as loading control. Data shown are representative of three independent experiments. 
(CSP) for 24 hours. Cells were then washed twice with $\mathrm{Ca}^{2+}-/ \mathrm{Mg}^{2+}-$ free PBS after treatments and incubated at $37^{\circ} \mathrm{C}$ for an additional 24 hours in fresh media. Whole cell lysates were collected from harvested cells after 24 hours. HeLa cells are cervical carcinoma cells containing HPV-16. HPV16 produces an active E6 which targets p53 degradation. Therefore I hypothesized that DDB2 should be present, but not be induced, in HeLa cells. Figure 16 reveals that p53 was induced by all 3 agents in A549/LXSN (p53+) cells. P53 was also present, but not induced with in response to DNA damaging agents, in A549/E6 (p53-) and HeLa (p53-) cells. With the exception of BPDE treated HeLa cells, p53 was not induced by the DNA damaging agents in the p53-deficient cell lines. DDB2 was present in all cell types. In A549/LXSN cells, DDB2 increased with BPDE and cisplatin treatments. In A549/E6 cells, all DNA damaging agents decreased levels of DDB2 compared to untreated control. DDB2 was present in HeLa cells, but not induced, by treatment with DNA damaging agents.

\section{Curcumin does not change the repair rate in $\mathbf{A 5 4 9}$ cells}

To determine whether curcumin alters the overall repair rate of BPDE-induced DNA damage, the relative amounts of BPDE-DNA adducts remaining after BPDE exposure were measured over time using immunoslot blot assay (Figure 14). Cells were pretreated with or without curcumin for $24 \mathrm{~h}$, exposed to 50 (Figures 17A and 17D), 100 (Figures $17 \mathrm{~B}$ and 17E) or $300 \mathrm{nM}$ (Figures $17 \mathrm{C}$ and 17F) BPDE, and DNA collected at 0 (immediately after 1 hour BPDE treatment), 6, and 24 hours. The relative amount of BPDE-DNA adducts remaining in A549/LXSN (p53+) cells decreased with increasing time for all three treatments (Figures 17A-17C). Curcumin pretreatment did not change the overall removal rate of BPDE adducts in A549/LXSN cells. The relative BPDE-DNA adduct levels in A549/E6 (p53-) cells treated increased over time (Figures 17D-17E). The relative amount of BPDE-DNA adducts significantly increased over time with 


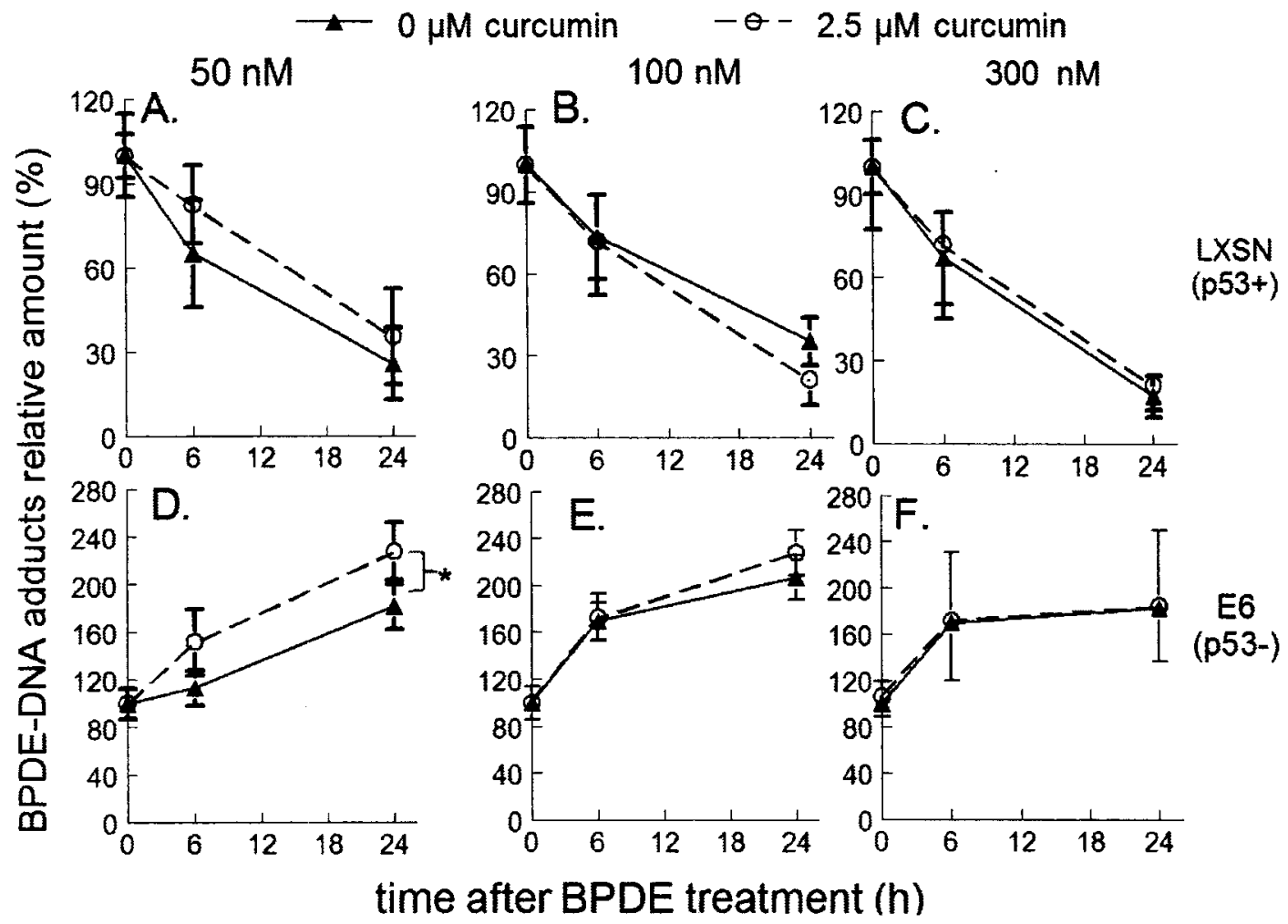

Figure 17. Immunoslot blot analysis of BPDE-DNA adducts remaining immediately (0), 6 and $24 \mathrm{~h}$ after BPDE treatment. A549/LXSN (p53+) (A through C) and A549/E6 (p53-) (D through F) cells were treated with 0 (closed triangles) or $2.5 \mu \mathrm{M}$ curcumin (open circles) for $24 \mathrm{~h}$. Cells were treated with 50 ( $A$ and $D), 100(B$ and $E)$ or $300 \mathrm{nM}(C$ and $F)$ BPDE for 1 hour and washed twice with $\mathrm{Ca}^{2+}-\mathrm{Mg}^{2+}$-free PBS. Cells were either immediately harvested $(0 \mathrm{~h})$ or incubated with fresh media for an additional 6 or $24 \mathrm{~h}$. Genomic DNA was purified from harvested cells and subjected to immunoslot blot assay. BPDE-DNA adducts in genomic DNA were measured using anti-BPDE DNA specific antibodies. The difference between DNA from BPDE treated cells and DNA untreated cells were calculated. The values from triplicate samples were averaged and normalized to values for 0 hour repair samples for each BPDE exposure. Data presented as means \pm STDEV of relative amount of BPDE-DNA adducts in three independent experiments. A two-way ANOVA test was used to compare curcumin vs. control group. Any significant changes were noted as ${ }^{\star} p<0.05$. 
curcumin pretreatment in A549/E6 cells exposed to $50 \mathrm{nM}$ BPDE. On the other hand, curcumin pretreatment did not change the relative amount of BPDE-DNA adduct levels in A549/E6 cells exposed to 100 and $300 \mathrm{nM}$ BPDE (Figure 17D). Overall these results suggest that removal of BPDE-DNA adducts depends on p53-expression. Yet, curcumin does not influence the rate of BPDE-DNA adduct removal.

\section{Curcumin influence on GSH system}

It is unclear whether curcumin changes the activity of GST in a p53-dependent manner. GST-alpha (GSTA), GST-mu (GSTM), and GST-pi (GST) are known to inactivate BPDE [36;64;107;120]. Because I found in Figures 11 and 17 that curcumin prevented BPDE-DNA adduct formation only in p53+ cells, yet had no profound influence on the DNA repair rate, I determined whether GSH and GST may play a role in eliminating BPDE-DNA adduct. Therefore, I pretreated cells with or without curcumin for 24 hours, followed by either 0 (THF; BPDE control solvent), 50, 100, or $300 \mathrm{nM}$ BPDE for 1 hour and immediately harvested the cells $(0 \mathrm{~h})$ to analyze GSTA, GSTM, and GSTP (Figures 18 through 19). Also, I examined whether p53 expression, curcumin pretreatment, and BPDE exposure change GST activity and GSH levels (Figures 20 and 21). GSTP levels (Figures $15 \mathrm{~A}$ and $15 \mathrm{~B}$ ) were not changed by p53-expression, curcumin pretreatment, or BPDE exposure. GSTA and GSTM were examined, but were not present in p53-expressing or non-expressing (Figure 18). P53 expression did not influence the relative amount of GST activity (Figure 19). Curcumin lowered GST activity in both cell lines exposed to $50 \mathrm{nM}$ BPDE. P53 expression and curcumin pretreatment affected GSH levels in cells exposed to 50 and $100 \mathrm{nM}$ BPDE (Figure 20). When cells were treated with $50 \mathrm{nM}$ BPDE, GSH levels in A549/LXSN cells were significantly higher than A549/E6 cells. Also, curcumin significantly increased GSH levels in A549/E6 cells treated with $100 \mathrm{nM}$ BPDE in contrast to A549/E6 cells exposed to $100 \mathrm{nM} \mathrm{BPDE}$ only. 


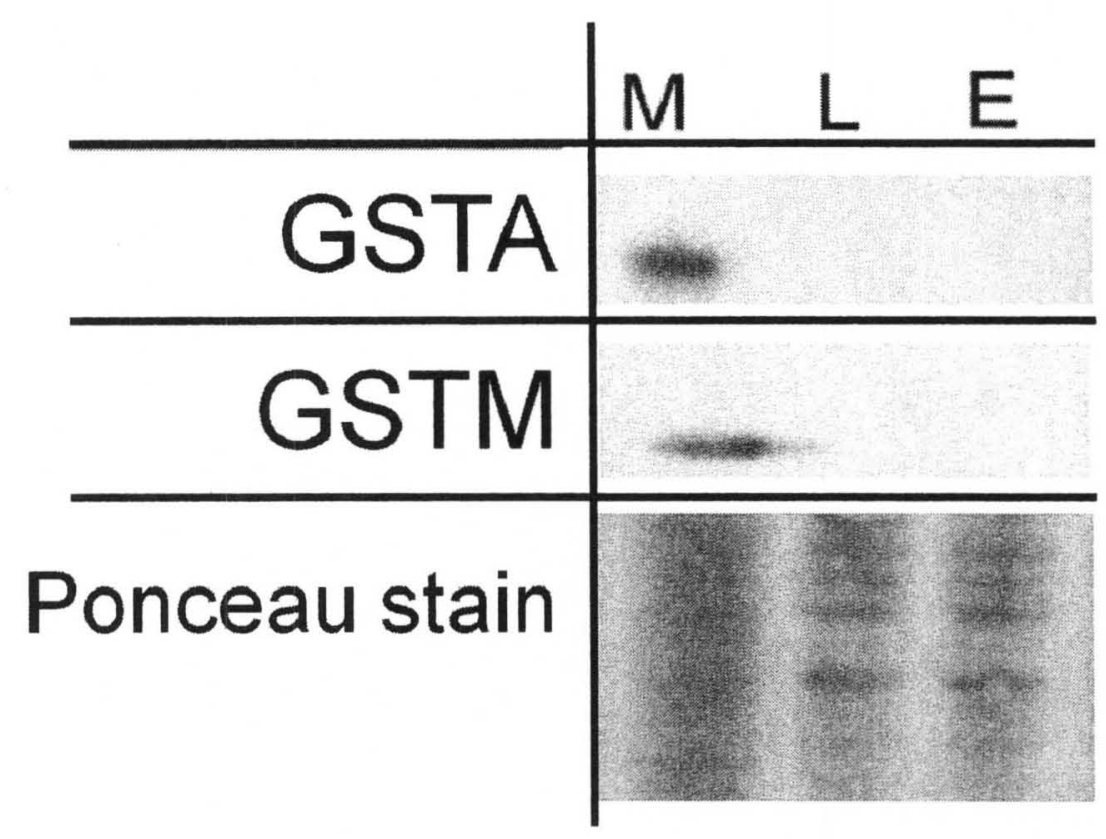

Figure 18. GSTA and GSTM are not present in A549 cells. Murine liver cells (M), untreated A549/LXSN (p53+; L) and A549/E6 (p53-; E) proteins were separated on 10\% SDS-PAGE. Samples were analyzed to evaluate the presence of GST-alpha (GSTA) and GST-mu (GSTM). Mouse liver cells served as a positive control for GSTA and GSTM expression. Ponceau stain served as the loading control. 
A

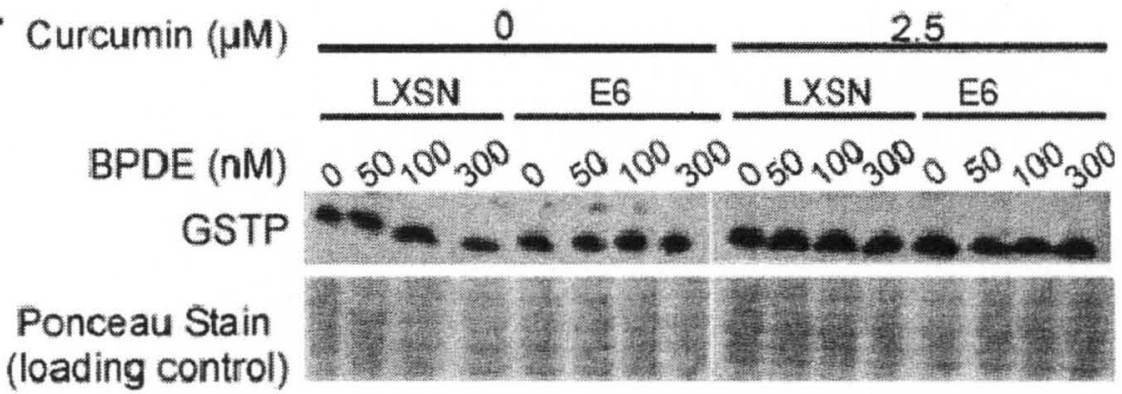

$\operatorname{LXSN}=A 549 / \operatorname{LXNN}(\mathrm{p} 53+)$

$E 6=A 549 / E 6(p 53-)$

B.

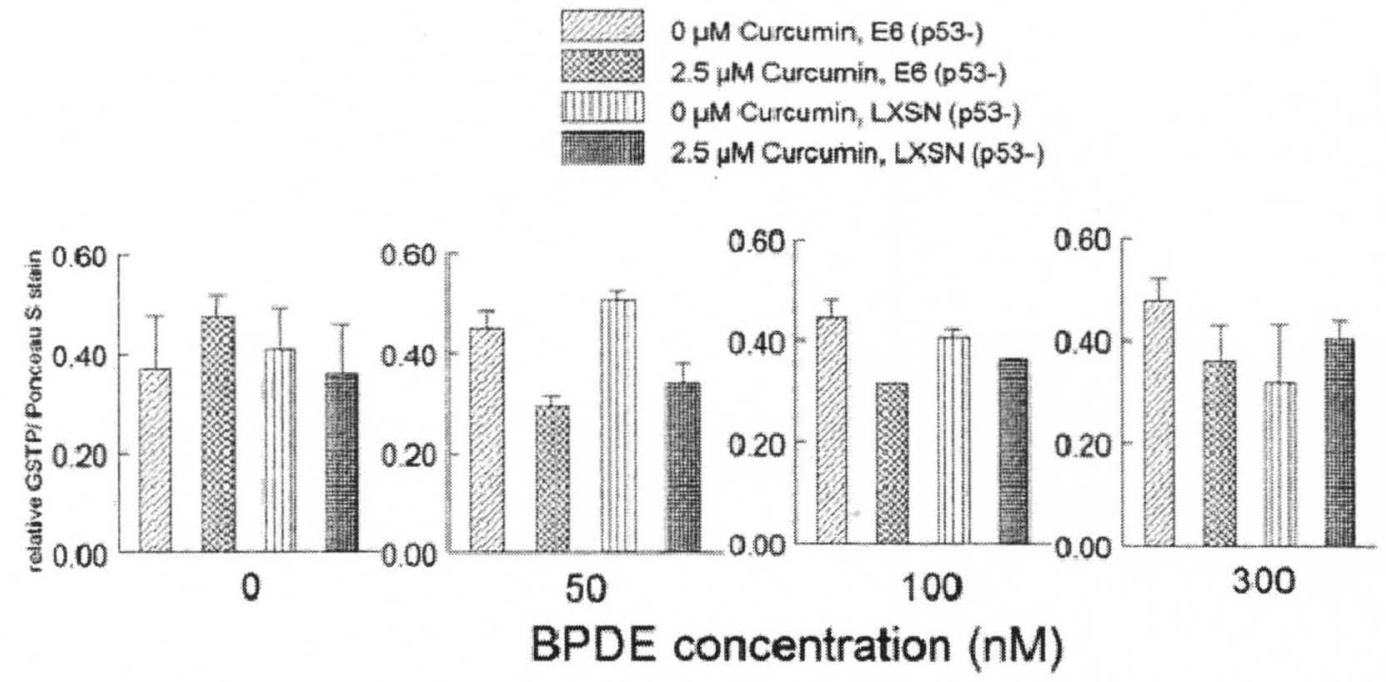

Figure 19. Effects of curcumin pretreatment and p53 expression on GST protein levels and activity. A549/LXSN (p53+) and A549/E6 cells were pretreated with 0 or $2.5 \mu \mathrm{M}$ curcumin for 24 hours. Then cells were exposed to $0,50,100$ or 300 nM BPDE for 1 hour, harvested immediately $(0 \mathrm{~h})$, then sonicated and homogenized and analyzed $(A)$ and quantitated by Western blot (B). Errors bars for GSTP protein levels indicate means \pm STEDV of GST protein levels against Ponceau stain (loading control) in two independent experiments. 


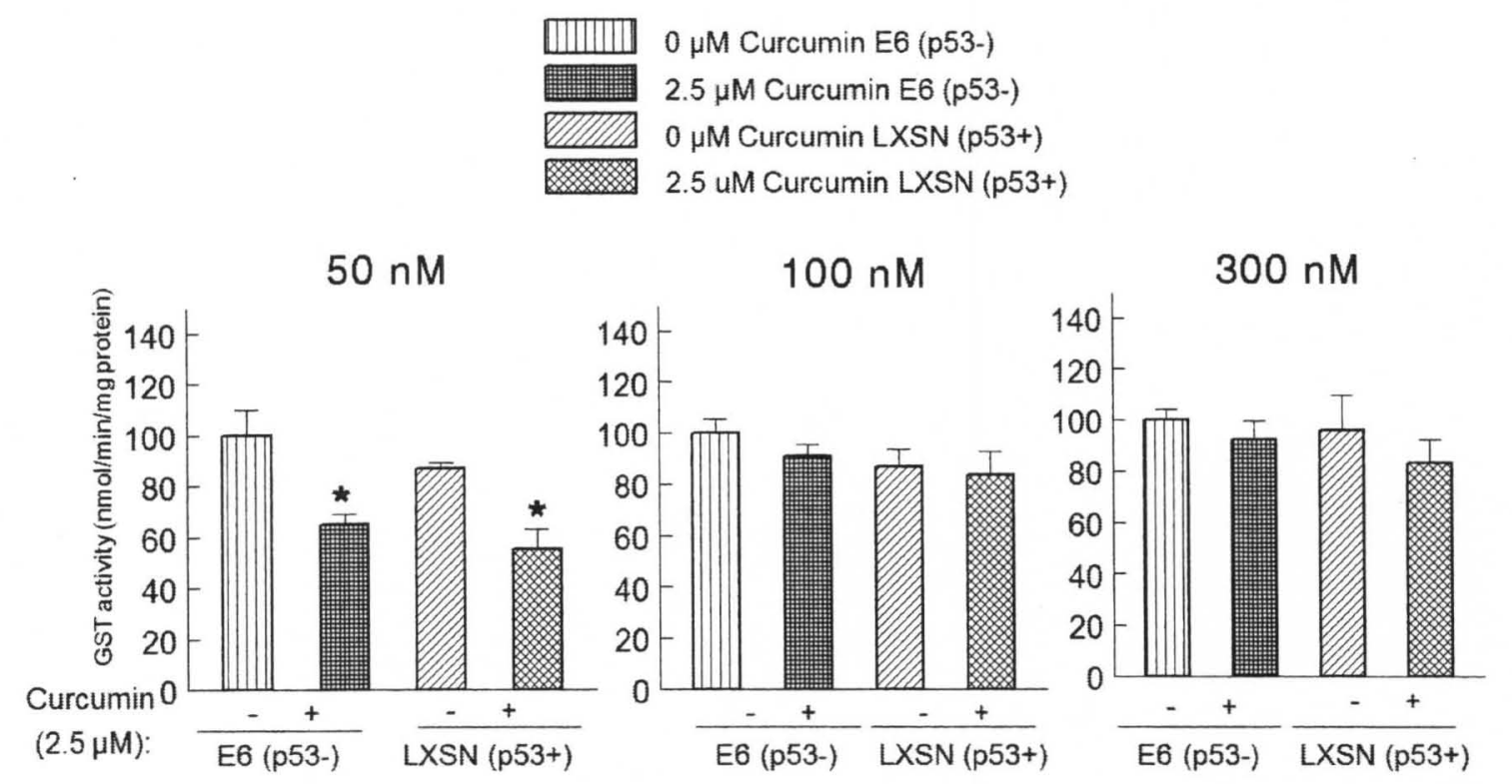

Figure 20. Effects of curcumin pretreatment and p53 expression on GST protein levels and activity. A549/LXSN (p53+) and A549/E6 (p53-) cells were pretreated with 0 or 2.5 $\mu \mathrm{M}$ curcumin for 24 hours. Then cells were exposed to $0,50,100$ or $300 \mathrm{nM}$ BPDE for 1 hour and harvested immediately (0 h). A549 cells were sonicated, homogenized for GST activity assay. A549/E6 cells exposed only to BPDE were expressed as $100 \%$ for each BPDE exposure. All others were compared to A549/E6 BPDE treated cells. Data are represented as means \pm STDEV of relative GST activity from three independent experiments. * denotes $p<0.05$ vs. compares with respective A549 cells pretreated with and without curcumin and BPDE exposure. 
Overall, GSH levels were not significantly altered by p53 expression, curcumin pretreatment, or BPDE exposure in these cells (Figure 21). Therefore, these results indicate that the GSH system does not play a significant role in reducing BPDE-DNA adducts. 


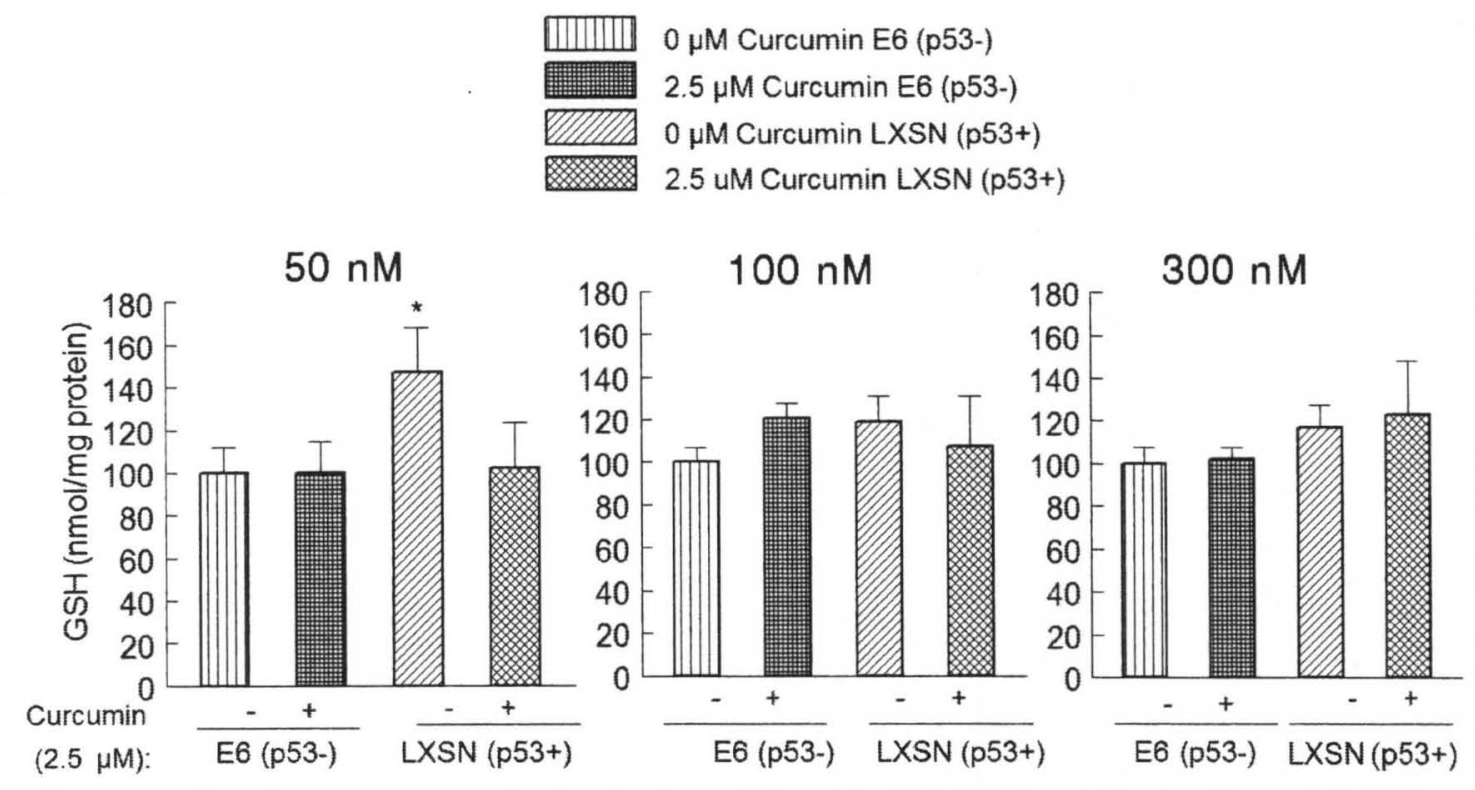

Figure 21. Effects of curcumin pretreatment and p53 expression on the activity on cellular-reduced GSH levels. A549/LXSN (p53+) and A549/E6 cells were pretreated with $0 \mu \mathrm{M}$ (DMSO) or $2.5 \mu \mathrm{M}$ curcumin for $24 \mathrm{~h}$. Then cells were exposed to $0,50,100$ or $300 \mathrm{nM}$ BPDE for 1 hour, harvested immediately $(0 \mathrm{~h})$, then sonicated and homogenized for measurement of the cellular-reduced GSH levels. A549/E6 cells exposed only to BPDE were expressed as $100 \%$ for each BPDE exposure. All others were compared to A549/E6 BPDE treated cells. Data are represented as means \pm STDEV of relative GSH levels from three independent experiments. * denotes $p<0.05$ vs. E6 cells pretreated with DMSO (curcumin control) and BPDE 


\section{Discussion}

$\mathrm{BaP}$ is an environmental carcinogen that is metabolized into the ultimate carcinogen BPDE. BPDE poses a health risk to humans because it can bind and damage DNA. If BPDE-DNA adducts are not repaired, then resulting mutations may accumulate and ultimately lead to cancer. Many reports show that activated p53 signals DNA repair in response to high concentrations of $\mathrm{BaP}(\geq 100 \mathrm{nM})[13 ; 15 ; 117]$. Environmental exposure to BaP, however, is relatively low which results in low BPDE from metabolized BaP. Thus, the physiological concentration of BPDE is much lower than those used in most in vitro studies; as a result, p53 remains inactive. Studies show that curcumin reduces BPDE-induced DNA damage, yet its exact mechanism of action remains unclear. Specifically, it is unclear whether curcumin lowers BPDE-DNA adducts by influencing p53-mediated DNA repair mechanisms.

Several separate contradictory reports show that p53 expression and curcumin treatment influence the development of BaP-derived DNA adducts. Sound data shows that $p 53$ is up-regulated in response to BPDE-induced DNA damage [124-127]. Additionally, in vitro and in vivo studies report curcumin as an inhibitor of BPDE-DNA adducts. Topical application of curcumin in mice, for example, inhibits BaP conversion into BPDE [128]. Another study reports that curcumin inhibits BaP-induced DNA strand breaks in human peripheral blood lymphocyte cells [6]. However, little is known whether curcumin has an influence on p53 and p53-mediated responses in response to BPDEderived DNA adducts rather than BaP-derived DNA adducts.

A possible connection between curcumin and p53-mediated responses in the reduction of BPDE-induced DNA damage has been investigated including the ability of curcumin to augment p53-dependent apoptosis [129]. Yet, the influence of curcumin on p53 expression and function is quite controversial as a recent report suggests that curcumin may in fact inhibit rather than stimulate p53 activity $[130 ; 131]$. 
Although an overwhelming number of reports indicate that curcumin exerts a protective mechanism in response to BPDE-induced DNA damage, my study shows for the first time a link between curcumin pretreatment and p53-expression in reducing BPDE-DNA adducts. In particular, curcumin significantly reduced BPDE-DNA adducts in a p53-dependent manner in A549 lung epithelial cells (Figure 11 and Table 1). BPDEDNA adducts were significantly higher in A549/E6 (p53-) cells and not changed by curcumin pretreatment. It should be noted that relative amounts of BPDE-DNA adducts were assessed on different membranes depending on the BPDE concentration used. Thus, relative BPDE-DNA adducts cannot be compared between different BPDE concentration groups. This study, consistent with others, shows that p53 is up-regulated in a concentration-dependent manner in response to BPDE-induced DNA damage in A549/LXSN cells (Figure 12 and 14). Curcumin pretreatment increased p53 upregulation in p53-expressing cells. In contrast, p53 was absent in A549/E6 cells in response to curcumin and BPDE treatment. Therefore the results of this chapter demonstrate that curcumin reduces BPDE-induced damage by increasing p53.

Activated p53 signals a number of cellular responses including DNA repair [97;132]. While I showed that BPDE-DNA adduct formation was p53-dependent and significantly reduced in the presence of curcumin in p53-expressing cells, the overall removal rate of BPDE-DNA adducts was dependent of p53 expression not curcumin pretreatment (Figure 17). Additionally, BPDE-DNA adducts in p53-deficient cells increased in a time-dependent manner. This observation is consistent with other studies which also show an increase of BPDE-DNA adducts over time in p53-deficient cells. BPDE is a hydrophobic compound which readily lodges in the cell membrane [133;134]. The absence of $p 53$, and thus lack of protective mechanism, prevents removal of BPDEDNA adducts. Inefficient removal of BPDE therefore increases the formation of BPDEDNA adducts over time as BPDE leaves the lipid depots. 
Recognition of DNA adducts by XPC and DDB2 is the rate limiting step which initiates the GGR pathway. While an overwhelming amount of data shows p53 regulates basal and inducible expression of XPC and DDB2, these studies were implemented in fibroblasts [59;97-99]. My results, on the other hand, revealed that XPC and DDB2 are not induced by p53 expression in A549 cells (Figures 12 and 14). Curcumin pretreatment enhanced XPC, but not DDB2, expression in a p53-independent manner. Yet, XPC and DDB2 levels were not induced by BPDE treatment. Contrasting studies revealed that the basal and inducible expressions of XPC and DDB2 are not only regulated by p53 [135]. Recent studies have shown that human keratinocytes, unlike fibroblasts, do not require p53 to maintain basal levels of XPC and DDB2 [136-138]. In fact it is suggested that $p 63$, an isoform of $p 53$, modulates repair of DNA damage in human keratinocytes [138;139]. Also, strong evidence for the functional interaction between DDB2 and the transcription factor E2F1, a proliferative marker in many cancers, has been implicated in cancer cell growth [136;140]. Because I used epithelial cells rather than fibroblasts, possible cross talk between E2F1 as well as modulation by p53 isoforms like p63 could explain the presence, but not induced form of DDB2. Therefore XPC and DDB2 in A549 cells may be regulated by multiple proteins other than p53.

Nevertheless, the results from this study show that curcumin significantly reduced BPDE-DNA adducts in a p53-dependent; yet, XPC and DDB2 are not induced in response to BPDE-induced DNA damage (Figures 12 and 14). Thus, p53 may regulate other steps of the NER system besides DNA damage recognition. Studies show p53 physically binds to the TFIIH helicase subunits, XPB and XPD [123;141;142]. XPB and XPD are important proteins which unwind the damage DNA complex to expose damage thereby creating the substrate for cleavage (Figure 6). It is also suggested that p53 may function as a chromatin accessibility factor in NER [143]. That is, in response to 
DNA damage, p53 signals chromatin relaxation which subsequently extends over the entire genome. As a result, global chromatin relaxation leads to bulky DNA damage recognition over the entire genome by the GGR system. It is unclear whether curcumin influences the activity of TFIIH helicase or the chromatin accessibility factor. On the basis of the present findings, a possible mechanism by which curcumin reduces BPDEDNA adducts is summarized in Figure 22.

The conjugation of BPDE to GSH by GST is believed to be the most important enzymatic pathway to inactivate BPDE [61;62;107]. Studies have suggested that GST interacts with p53 expression to provide a protective mechanism against BPDE-induced DNA damage $[64 ; 109]$. Furthermore, it has been shown that administration of curcumin may inhibit BaP-induced forestomach tumorigenesis in mice by increasing hepatic GST activity [5]. My study, however, shows that GST activity along with GSTP and GSH levels were not influenced by curcumin pretreatment or p53 expression in response to BPDE-induced DNA damage (Figures 17 through 21). Therefore curcumin pretreatment does not reduce BPDE-DNA adducts in a p53-dependent manner by modulating BPDE inactivation through glutathionylation. While the GSH system is the most prominent pathway to inactivate BPDE-induced DNA damage, other phase II detoxifying systems including NADPH:quione reductase may be involved.

Possible direct interaction between curcumin and BPDE may also reduce levels of BPDE-DNA adducts. Computational studies show the naturally occurring compound, ellagic acid, also prevents BPDE-DNA adducts [144;145]. Ellagic acid, like curcumin, is a polyphenol (Figure 23). Huetz et. al, among others, demonstrated that the phenolic $\mathrm{OH}$ group of ellagic acid forms a chemical bond with the epoxy ring of BPDE [81;146-148]. Thus ellagic acid acts as a scavenger by physically binding to BPDE. Studies also show other compounds including thiol-containing purine analogues covalently bind to BPDE [133;134]. While both curcumin and ellagic acid are characterized as polyphenols only 


\section{Curcumin}

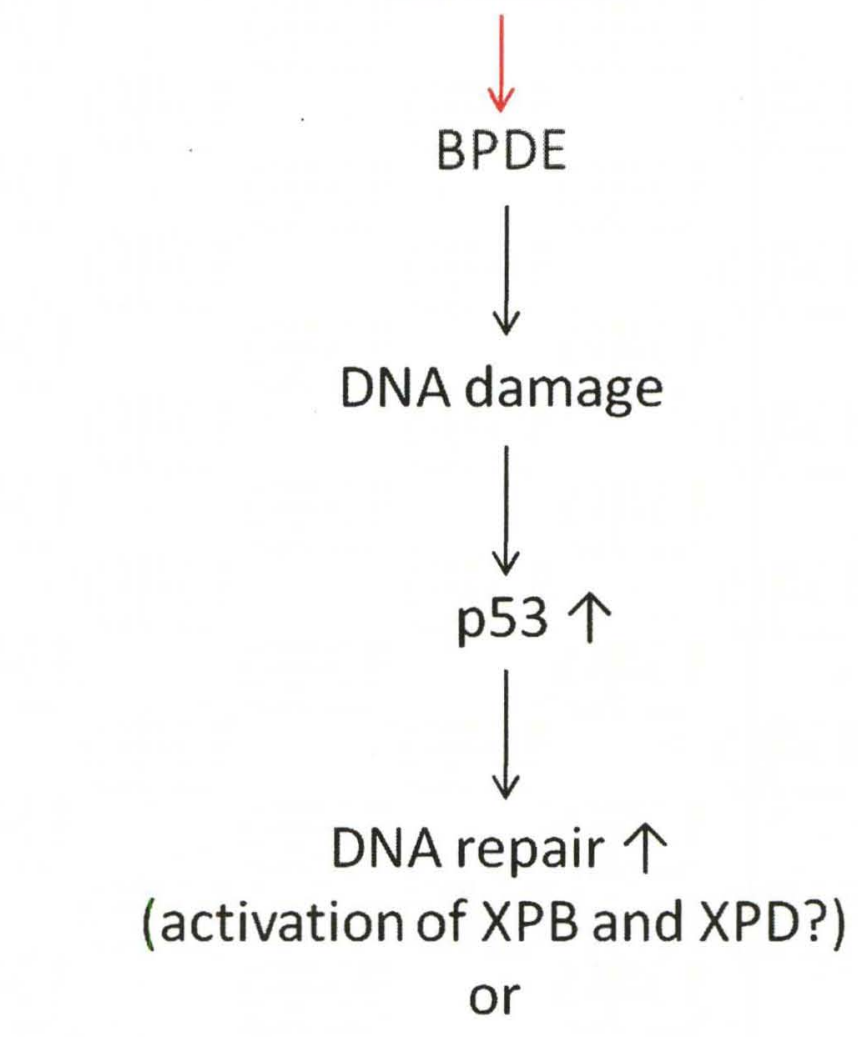

(chromatin assembly factor activated?)

$\downarrow$

BPDE-DNA adducts removed

Figure 22. Possible mechanism by which curcumin reduces BPDE-DNA adducts.

Curcumin pretreatment in response to BPDE-induced DNA damage increases p53

levels. As a result, BPDE-DNA adducts are removed. Because XPC and DDB2 levels did not change with curcumin pretreatment and p53 expression, this figure speculates that other p53-mediated DNA repair proteins are involved. Namely, p53 may activate helicase XPB and XPD of the NER system as well as chromatin assembly factor in order to repair BPDE-DNA adducts in a p53-dependent manner. 

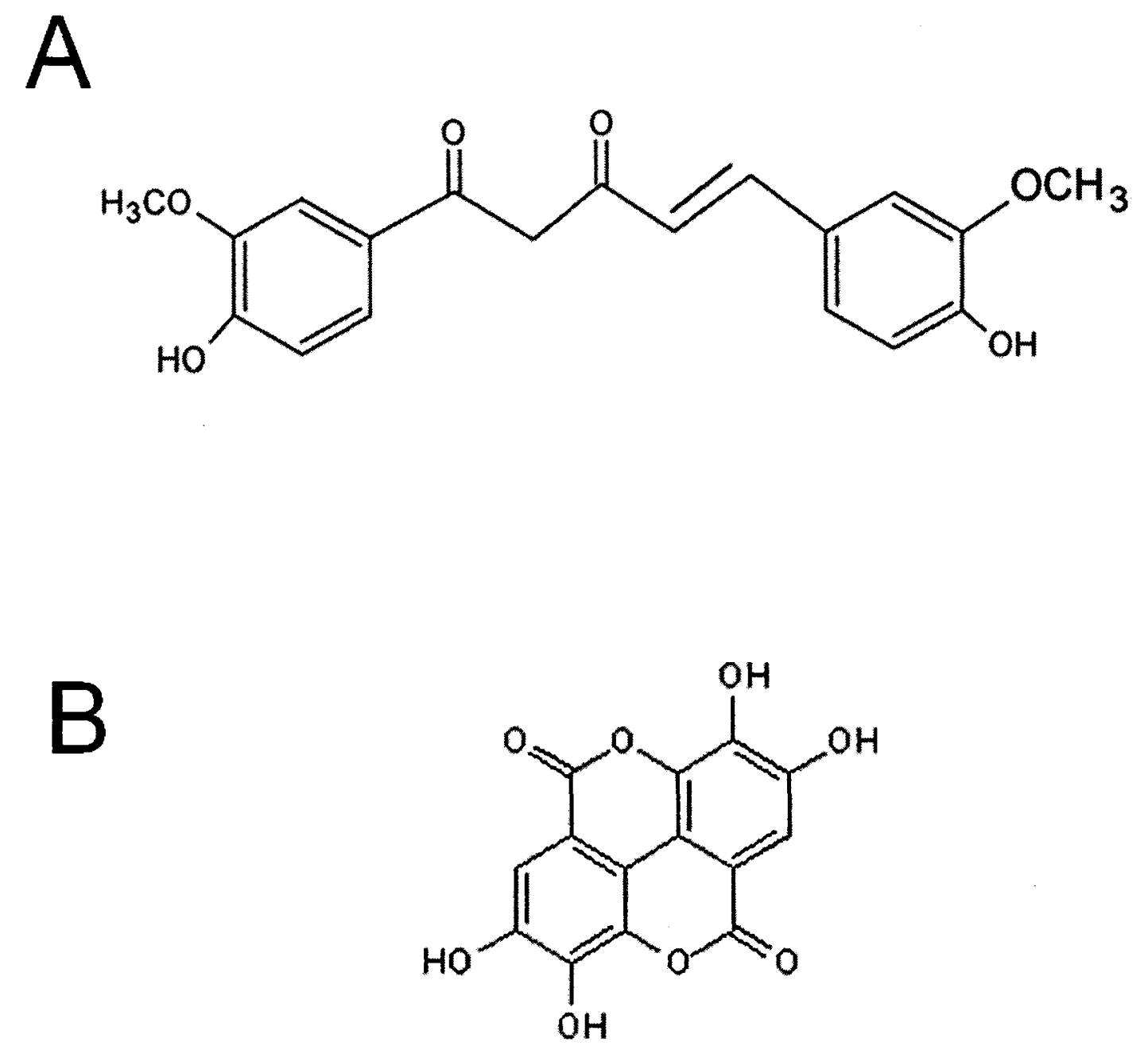

Figure 23. Structures of curcumin (A) and ellagic acid (B). (A) Adapted from "Curcumin, resveratrol and flavonoids as anti-inflammatory, cyto- and DNA-protective dietary compounds," by K. Bisht, 2010, Toxicology 278(1), p. 88-100. (B) Adapted from "Reaction between ellagic acid and an ultimate carcinogen," by P. Huetz, 2005, J.Chem.Inf.Model, v. 45, no. 6, p. 1564-1570. 
ellagic acid possesses cis diols. Therefore, curcumin may in fact change its conformation such that its phenol groups are positioned like cis diols. As a result, the different conformation of curcumin may allow it to act as a scavenger and bind to BPDE. To date there is no evidence which shows whether curcumin forms a chemical bond with BPDE.

In conclusion, this chapter shows that curcumin reduces BPDE-DNA adduct formation in a p53 dependent manner. However curcumin does not impact XPC, DDB2, or the GSH system in order to decrease BPDE-DNA adducts in a p53-dependent manner. Additionally, curcumin pretreatment did not influence how rapid BPDE-DNA adducts are removed. Therefore, further studies are needed to determine the exact mechanism of action by which curcumin prevents BPDE-DNA adducts in a p53dependent manner. 


\title{
CHAPTER III
}

\section{CURCUMIN AFFECTS CELL CYCLE ARREST AND APOPTOSIS IN HUMAN LUNG EPITHELIAL CELLS IN RESPONSE TO BPDE-INDUCED DNA DAMAGE}

\author{
Introduction
}

Humans are exposed to a host of environmental carcinogens such as polycyclic aromatic hydrocarbons (PAHs). One of the most potent PAHs is benzo[a]pyrene (BaP) [149]. BaP, a PAH well characterized in both human and animal model systems, is best described as an ubiquitous carcinogen produced by incomplete combustion of organic matter [37]. While BaP is converted into a number of metabolites, $7 R, 8 S$-dihydroxy-9S, 10R-epoxy-7, 8, 9, 10-tetrahydrobenzo[a]pyrene (BPDE) is the most carcinogenic derivative $[150 ; 151]$. Characterized by a bay region which promotes its highly reactive electrophilic activity, BPDE readily binds to nucleophiles [152]. BPDE, however, primarily attaches to the exocyclic amino group of guanine bases bulky adducts on DNA $\left(\mathrm{N}^{2}\right.$ BPDE-dG). When BPDE-DNA adducts are not repaired, detrimental effects such as mutations may occur which lead to cancer.

Activation and stabilization of the suppressor protein p53 is an important event in response to DNA damage [153;154]. In unstressed cells, p53 protein levels are low due to HDM2-mediated ubiquitinylation and degradation [42]. As a result, cyclins and cyclin dependent kinase (CDKs) interact with each other to induce phosphorylation of retinoblastoma protein ( $p R b)$. Phosphorylated $p R b$ dissociates and activates E2F1. In turn, activated E2F1 induces the expression of genes such as cyclins $E$ and $A$ which 
promote cell cycle progression. However, when DNA damage is sensed, protein kinases ATM (ataxia telangiectasia, mutated)and ATR (ATM- and Rad3-related) are activated to phosphorylate p53 at Ser15 [155]. In addition, ATM and ATR can indirectly phosphorylate p53 at Ser20 by activating checkpoint kinases CHK2 and CHK1, respectively [156]. Phosphorylation of p53 at Ser15 and Ser20 inhibits the interaction between p53 and HDM2, resulting in p53 stabilization [157;158]. P53 stabilization slows p53 to be further modified and activated. Depending on the severity and duration of damage, activated p53 signals several cellular responses including cell cycle arrest. As a result, induction of cell cycle arrest will allow sufficient time for repair of BPDE-DNA adducts.

Up-regulation of the cyclin dependent kinase inhibitor (CDKI) CDKN1A (also known as $\mathrm{p} 21^{\mathrm{WAF} 1 / \mathrm{ClP} 1}$ ) in response to $\mathrm{p} 53$ activation is a common mechanism that signals cell cycle arrest. CDKN1A expression prevents the interaction between cyclinCDK complexes and subsequent pRb phosphorylation [159]. As a result, hypophosphorylated $\mathrm{pRb}$ remains bound to and inactivates $\mathrm{E} 2 \mathrm{~F}$, thereby promoting cell cycle arrest until DNA is repaired. In addition to signaling a p53-mediated cell cycle arrest, it is well established that BPDE treatment causes S-phase arrest in p53-null cells. BPDE-DNA adducts interfere with DNA replication which are sensed by ATR $[155 ; 160]$. Consequently, CHK1 is phosphorylated and activated at Ser317 and Ser345, phosphatase Cdc25A is targeted for degradation. As a result, lack of Cdc25A expression inhibits dephosphorylation of the cyclin E/A-cdk2 complex and S phase arrest occurs [122]. Collectively, activated p53 and CHK1 signal cell cycle arrest which allows time for DNA to be repaired. However, physiological exposure to BPDE is relatively low and fails to signal cell cycle arrest. Thus unrepaired DNA damage leads to an increased likelihood of mutations which ultimately result in cancer. 
Epidemiological studies indicate a low incidence of certain cancers, such as lung cancer, in the Eastern World compared to Western countries [72]. Researchers speculate the disparity between certain cancers could be due to lifestyle, including diet. Among the dietary agents linked to this disparity include curcumin. Curcumin is a polyphenolic compound from the rhizome plant Curcuma longa (Linn). This agent is heavily consumed in Asia, an area which exhibits a low incidence of cancer $[69 ; 72 ; 84 ; 161 ; 162]$. Curcumin is suggested to be a potent inhibitor of DNA damage and tumor development $[83 ; 87 ; 163]$. Numerous independent studies have indicated that curcumin influences the expression of genes responsible for cell cycle progression. Namely, curcumin treatment in a variety of cancer cells up-regulated p53, CDKN1A, and p27 and down-regulate cyclins B, D, and E $[115 ; 164 ; 165]$. Additionally, pancreatic cancer cells treated curcumin resulted inactivation of the ATM/Chk1 pathway followed by cell cycle arrest and apoptosis. Curcumin has also been shown to inhibit chemical carcinogenesis by enhancing phase II metabolizing enzymes [100-102].

Although curcumin has been shown to decrease BaP-derived DNA adduct formation as well as induce p53, little evidence is available whether curcumin may induce cell cycle checkpoints in order to allow sufficient time for repair of BPDE-induced DNA damage. Therefore I investigated if curcumin regulates cell cycle arrest in response to BPDE-induced DNA damage independent of p53 expression. 


\section{Materials and Methods}

Cell cultures, curcumin treatment, and BPDE exposure

A549 cells were grown, treated with curcumin, and exposed to BPDE as previously described in Chapter II of this dissertation.

\section{Western Blot}

Protein lysates from cells were collected as previously described in Chapter II of this dissertation. Membranes were incubated with the following primary antibodies and dilutions as described by the manufacturer:anti-p53 monoclonal mouse antibody (NeoMarkers, Cat\# MS-187-P) (1:1000); anti-phospho-p53 Ser15 mouse polyclonal antibody (Cell Signaling Technology, Cat\#9284) (1:500); anti-caspase-3 rabbit polyclonal antibody (Cell Signaling Technology, Cat\#9662) (1:1000); anti-phospho-Rb Ser807/811 rabbit polyclonal antibody (Cell Signaling Technology, Cat\# 9308) (1:1000); anti-cyclin A rabbit polyclonal antibody (Cell Signaling Technology, Cat \# 4656) (1:1000); antiCDKN1A rabbit polyclonal antibody (also known as anti-p21) (Santa Cruz Cat \# sc756) (1:1000); or anti-cyclin E mouse monoclonal antibody (Cell Signaling Technology, Cat\# 4132) (1:2000). Mouse antibodies were bound by rabbit anti-mouse IgG conjugated to horseradish peroxidase. Rabbit antibodies were bound by goat anti-rabbit IgG conjugated to horseradish peroxidase for detection. Detection of GAPDH (Abcam, Cat\# ab9484) (1:10.000) or $\beta$-actin (Abcam, Cat\# ab8227) (1:10,000) served as the loading controls.

\section{Flow cytometry}

Cells were plated in $10-\mathrm{cm}$ dishes and treated with curcumin followed by BPDE as previously described in Chapter II. A549 cells were immediately collected ( 0 h), or 
refed with fresh BPDE-free media for $6,12,16$, or 24 hours. Upon collection, the cells were washed with $5 \mathrm{~mL} 1 \times$ PBS and $5 \mathrm{~mL}$ 1x PBSE (1x PBS containing 5mM EDTA). Cells were harvested by trypsinization with $1.5 \mathrm{~mL} 1 \mathrm{x}$ trypsin (Invitrogen, Cat\#15400054). Trypsinized cells were collected with media, and briefly centrifuged $(15,000 \times g)$ at room temperature. The supernatant was removed, the pellet was washed with $3 \mathrm{~mL}$ 1xPBS, and fixed in $70 \%$ ethanol (7 parts $100 \%$ ethanol and 3 parts $1 \times$ PBS) overnight at $4^{\circ} \mathrm{C}$. The next day the cells were centrifuged at $15,000 \times g$ to pellet. Then the cells were resuspsended in $1 X$ PBS and incubated at $37^{\circ} \mathrm{C}$ with RNase $A(100 \mu \mathrm{g} / \mathrm{mL})$ for $3 \mathrm{~h}$. The cells were stained with propidium iodide buffer (propidium iodide, $10 \mu \mathrm{g} / \mathrm{mL}$; Tween20, 0.5\%; RNase A, $0.1 \%$ in PBS) and incubated an additional $30 \mathrm{~min}$ in the dark at $37^{\circ} \mathrm{C}$. The fluorescence from stained samples was collected on channel 2 (FL2; 585/42 $\mathrm{nm}$ ) using linear amplification. A minimum of 20,000 events/sample were analyzed using FACSCalibur flow cytometer (BD Biosciences, San Jose, CA). Electronic gating was set up to remove any cell debris, cell doublets and cell clumps. The intensity of the cell's fluorescence was proportional to the amount of DNA in the cell. After standardization for each cell line using Cell Quest software (Becton Dickerson, Franklin Lakes, NJ), cells were assigned to different cell cycle compartments based on DNA content using FloJo software (Tree Star, Inc., Ashland, OR). 
Results

\section{Curcumin enhances p53, p53S15 and CDKN1A induction in response to BPDE- induced DNA damage}

Curcumin treatment has been shown to up-regulate p53. However, it is unclear if curcumin may increase p53 expression in response to BPDE-induced DNA damage. Therefore, we used Western blotting analysis to determine whether curcumin may influence p53 and p53-regulated cell cycle progression proteins. Figure 24A shows that p53, p53S15, and CDKN1A increased in a concentration- and time-dependent manner in A549/LXSN (p53+). P53, p53S15, and CDKN1A were not present in A549/E6 (p53-) cells (Figure 24B). Curcumin strongly induced p53, p53S15, and CDKN1A levels in p53+ cells in a concentration and time-dependent manner. Specifically, curcumin increased p53, p53S15, and CDKN1A in p53+ cells 24 hours after lower BPDE concentrations $(\leq 100 \mathrm{nM})$. Therefore these results indicate that CDKN1A is regulated by p53 expression and curcumin enhanced the stabilization and subsequent up-regulation of CDKN1A with lower BPDE concentrations.

\section{P-pRbS807/811 decreases in a p53-independent manner in response to BPDE- induced DNA damage}

Normally in unstressed cells, cyclins and CDKs (cyclin-CDKs) interact which subsequently phosphorylate $\mathrm{pRb}$. Phosphorylation of $\mathrm{pRb}$ causes $\mathrm{pRb}$ to dissociate from E2F1. E2F1, in turn, is activated and signals the upregulation of genes responsible for cell cycle progression (Figure 5). However, when CDKN1A is present, the cyclin-CDK complex is inhibited, thereby preventing cell cycle progression. Because I found in Figure 24A that curcumin up-regulates CDKN1A in p53-expressing cells in response to BPDE-induced DNA damage, I investigated if phosphorylated pRb (P-pRb) is downregulated. Specifically I examined pRb phosphorylated at Ser807/811. 


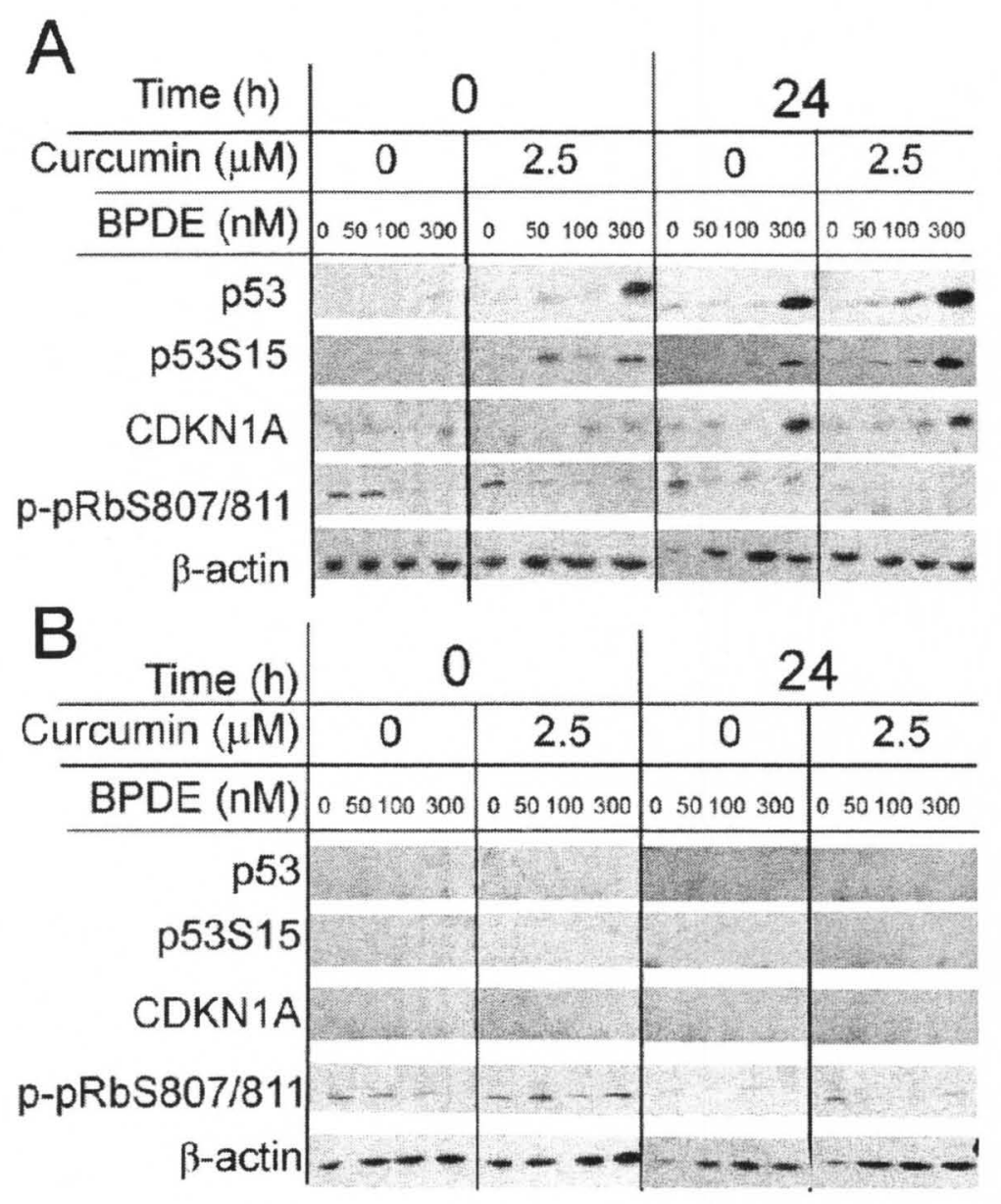

Figure 24. Curcumin enhances p53 and CDKN1A induction in response to BPDEinduced damage. A549/LXSN (p53+) (A) and A549/E6 (p53-) (B) were treated with or without $2.5 \mu \mathrm{M}$ curcumin for $24 \mathrm{~h}$. Next the cells were treated with $0,50,100$ or $300 \mathrm{nM}$ BPDE for $1 \mathrm{~h}$ and either harvested immediately $(0 \mathrm{~h})$ or $24 \mathrm{~h}$. Twenty micrograms of protein was loaded for Western blot analysis. The expression of p53, p5315 and CDKN1A were induced. P-pRbS807/811 decreased in response to BPDE-induced damage in p53+ cells. Pretreatment with curcumin increased the expression of p53, p5315 and CDKN1A, and decreased pRbS807/811 with lower BPDE concentrations. Data shown is a representative from three independent experiments. 
Unexpectedly, pRb phosphorylated at serines 807 and 811 (P-pRbS807/811) was affected in both cell lines. Figure 24A shows that levels of P-pRbS807/811 decreased in a concentration- and time-dependent manner in p53-expressing A549/LXSN cells after BPDE treatment. Curcumin pretreatment further reduced levels of P-pRbS807/811. P-pRbS807/811 in BPDE treated A549/E6 (p53-) cells also decreased in a concentration- and time-dependent manner. Curcumin pretreatment in A549/E6 cells enhanced P-pRbS807/811 levels. Taken together, these results suggest that curcumin pretreatment influences cell cycle arrest independent of p53 expression in response to BPDE-induced DNA damage.

\section{S-phase accumulation in response to BPDE-induced DNA damage is altered with curcumin pretreatment}

Flow cytomtery was used to determine the exact location of cell cycle arrest in response to BPDE-induced DNA damage. P53-expressing (Figure 25) or p53-deficient (Figure 26) cells were pretreated with 0 (A through $C$ ) or $2.5 \mu \mathrm{M}$ curcumin (D through $F$ ) for 24 hours. Cells were then exposed to 50 ( $A$ and $D), 100$ (B and E), or $300 \mathrm{nM}$ BPDE ( $\mathrm{C}$ and $\mathrm{F}$ ) for 1 hour. A549 cells were collected at 0 (immediately after BPDE treatment), $6,12,16$, or 24 hour after BPDE treatment.

A549/LXSN cells exposed to 50,100 , or 300 nM BPDE accumulated in S phase (Figure 25). Thus, S phase arrest occurs in response to BPDE-induced DNA damage in p53+ cells. P53+ cells escaped S phase arrest at different time points, depending on BPDE concentration. A549/LXSN cells treated with $\leq 100 \mathrm{nM}$ BPDE escaped S phase arrest after 12 hours (Figures 25A, B, D, and E). On the other hand, p53+ cells treated with $300 \mathrm{nM}$ BPDE did not escape S phase arrest until at least 16 hours after BPDE treatment (Figure $25 \mathrm{C}$ ). Curcumin pretreatment only affected A549/LXSN cells treated 
A.

B.

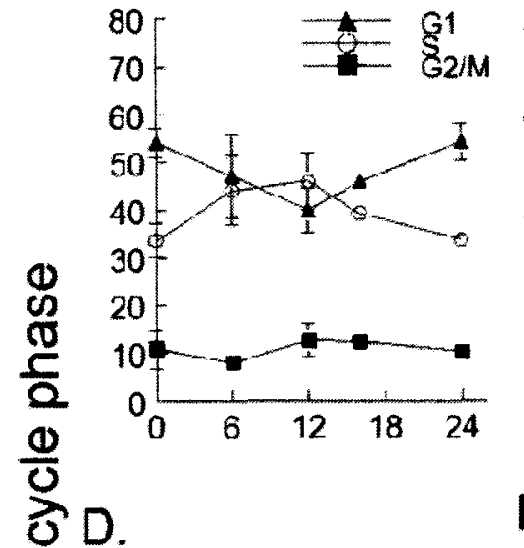

80

E.
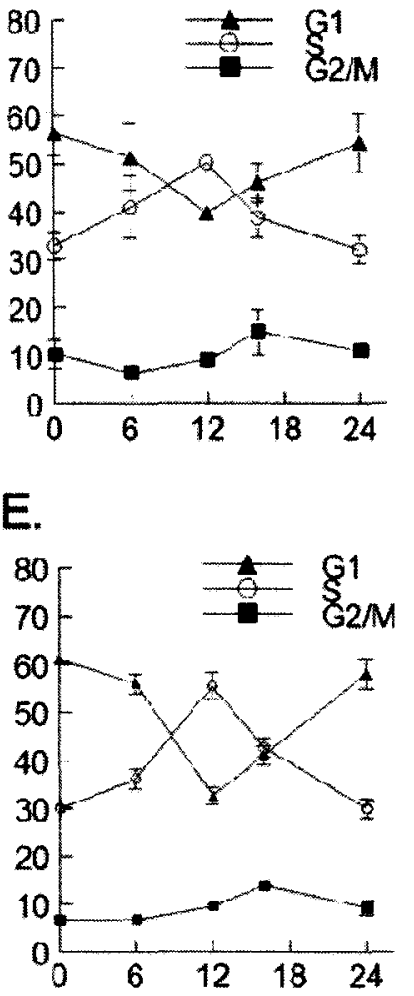

C.

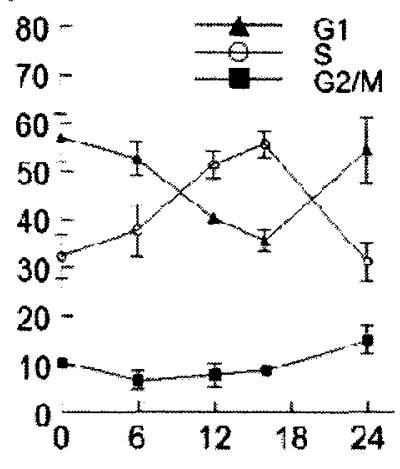

F.

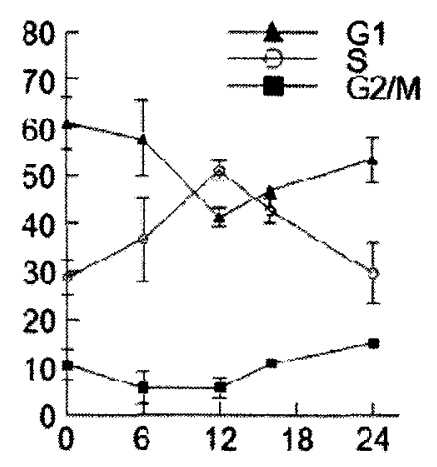

time after BPDE treatment (hr)

Figure 25. P53-expressing A549/LSXN cells transiently arrest in S-phase in response to BPDE-induced damage. A549/LXSN (p53+) cells were treated with 0 (A-C) or $2.5 \mu \mathrm{M}$ curcumin (D-F) for $24 \mathrm{~h}$. Then the cells were exposed to 50 (A and D), 100 ( $B$ and $E$ ), or $300 \mathrm{nM}$ BPDE (C and F) for $1 \mathrm{~h}$, harvested immediately (0), 6, 12, 16, or $24 \mathrm{~h}$ after exposure. P53+ cells were stained with propidium iodide and DNA content was analyzed using flow cytometry as described in methods. Data presented as mean \pm STDEV of three independent experiments. 
A.

B.

C.

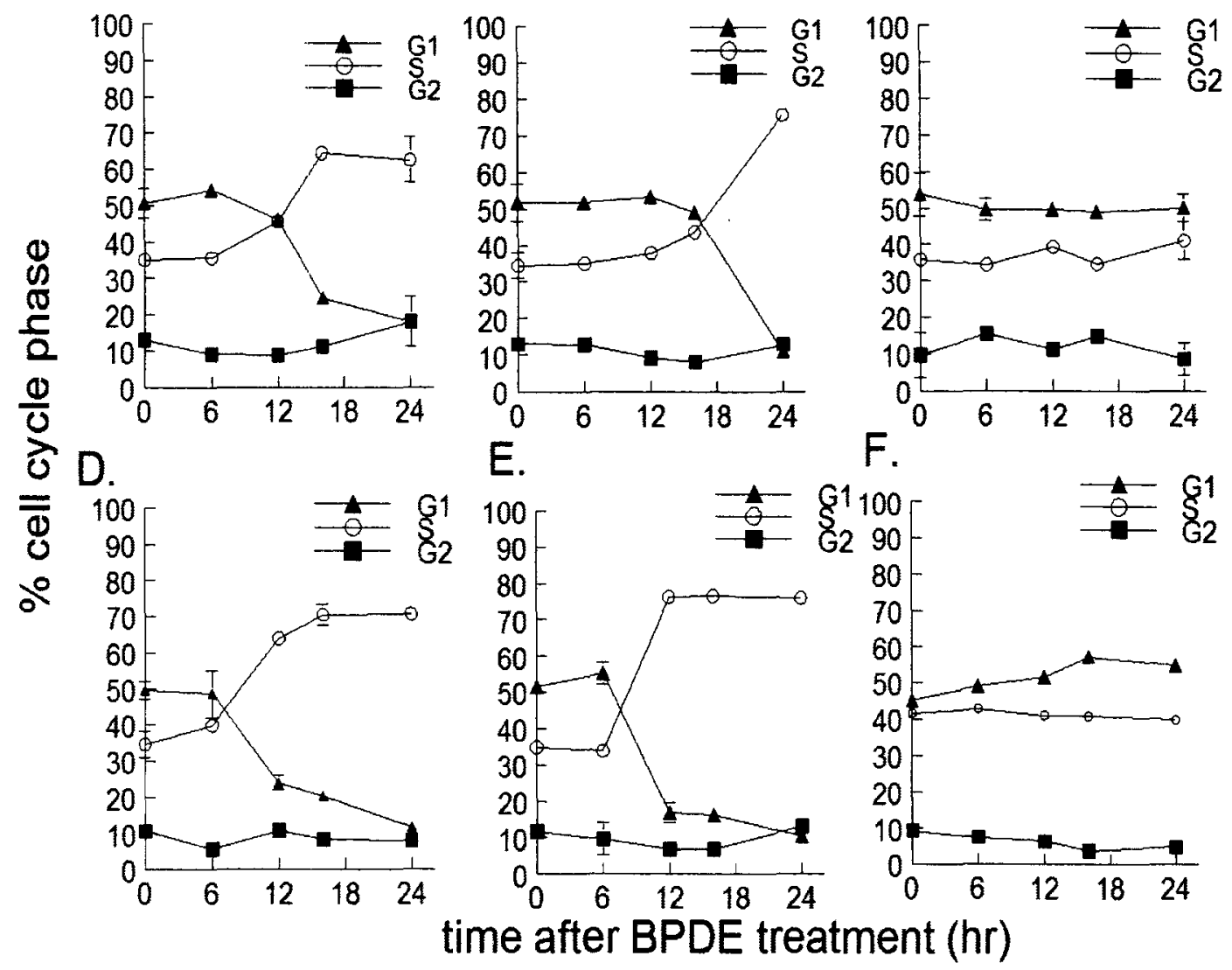

Figure 26. P53-deficient A549/E6 cells arrest in S phase, but never escape with lower BPDE concentrations. A549/E6 (p53-) cells were treated without (A-C) or with $2.5 \mu \mathrm{M}$ curcumin (D-F) for $24 \mathrm{~h}$. Then the cells were exposed to 50 ( $A$ and $D$ ), 100 ( $B$ and $E$ ), or $300 \mathrm{nM}$ BPDE ( $\mathrm{C}$ and F) for $1 \mathrm{~h}$, harvested immediately $(0 \mathrm{~h}), 6,12,16$, or $24 \mathrm{~h}$ after exposure. P53- cells were stained with propidium iodide and DNA content was analyzed using flow cytometry as described in methods. Data presented as mean \pm STDEV of three independent experiments. 
with $300 \mathrm{nM}$ BPDE (Figure 25F). Specifically, p53+ cells pretreated with curcumin followed by $300 \mathrm{nM}$ BPDE escaped S phase arrest after 12 hours.

Curcumin did not have an influence cell cycle progression in p53+cells treated at 50 and $100 \mathrm{nM}$ BPDE. Exposure to BPDE and curcumin also affected A549/E6 (p53-) cells (Figure 26). P53- cells accumulated in S phase around 12 and 16 hours after 50 (Figure 26A) and $100 \mathrm{nM}$ (Figure 26B) BPDE treatment, respectively. P53- cells treated with $300 \mathrm{nM}$ stagnant in S phase (Figure 26C). Curcumin pretreated A549/E6 cells accumulated in S phase 6 hours after 50 and $100 \mathrm{nM} \mathrm{BPDE} \mathrm{(25D} \mathrm{and} \mathrm{25E,}$ respectively). Curcumin pretreated p53-cells gradually accumulated in $\mathrm{G}_{1}$ in response to $300 \mathrm{nM}$ BPDE (Figure 26F).

\section{P53-expressing cells accumulate primarily within S-phase in response to BPDE- induced DNA damage}

S-phase is characterized by the expression of two cyclins: cyclin E and cyclin A. Cyclin $E$ regulates $G 1$-to-S transition, while cyclin $A$ is responsible for progression through the S-phase. Cyclins E and A were therefore examined in A549 cells treated with $300 \mathrm{nM}$ BPDE to determine where cells arrest when treated with BPDE (Figure 27). The results show that cyclin $A$, not cyclin $E$, increased in a time-dependent manner following $300 \mathrm{nM}$ BPDE treatment in p53-expressing cells (Figure 27A). Curcumin pretreatment in p53+ cells increased cyclin A 12 hours rather than 24 hours after $300 \mathrm{nM}$ BPDE treatment. Cyclins $E$ and A, however, were not affected by curcumin and/or BPDE treatment in p53-deficient cells (Figure 27B). Therefore the results from the Western blot support the flow cytometry data of $\mathrm{S}$ phase arrest in p53+ cells. 
A

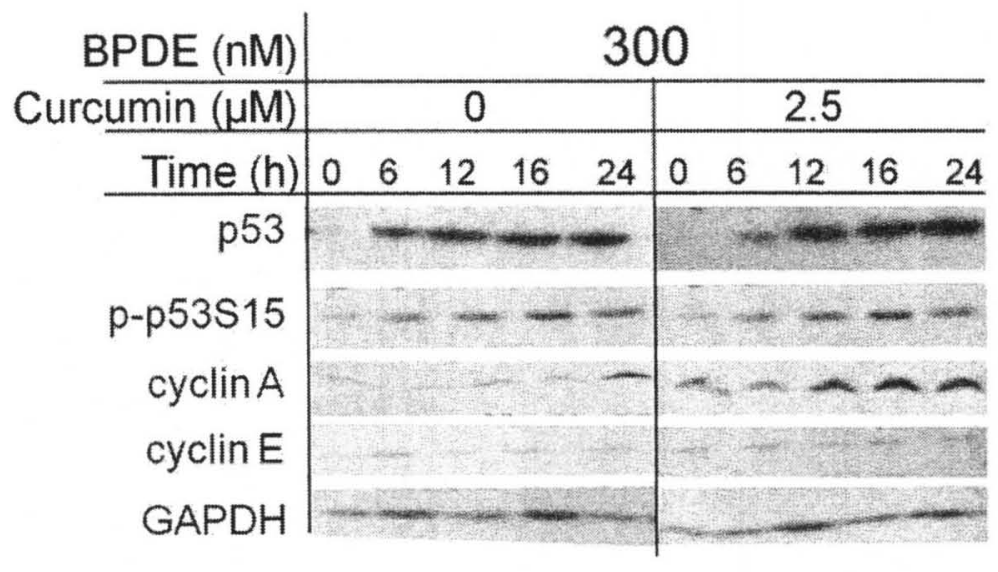

B

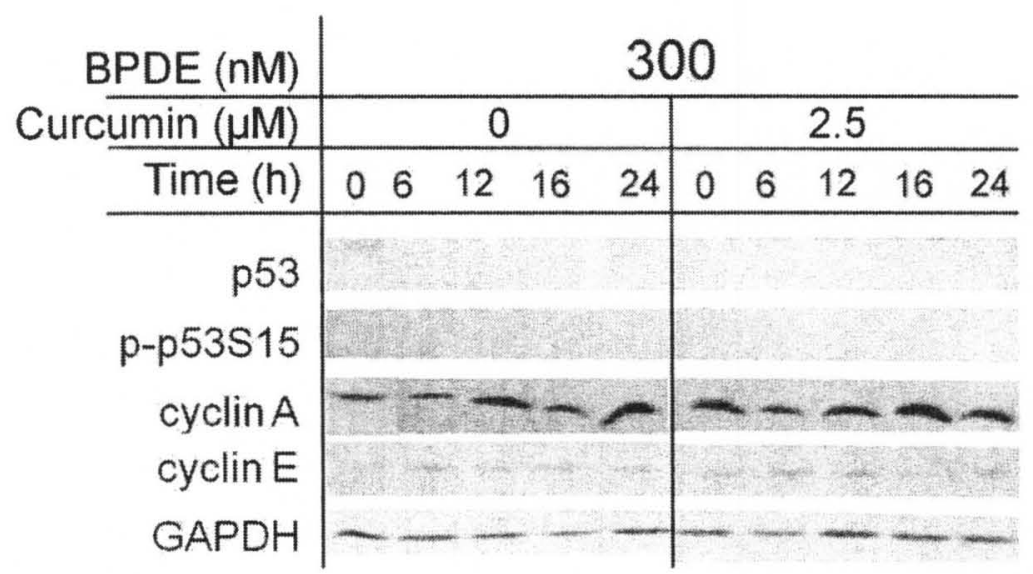

Figure 27. Levels of cyclin $A$ and $E$ in response to curcumin pretreatment and exposure to BPDE. A549/LXSN (p53+) (A) and A549/E6 (p53-) (B) were treated with or without 2.5 $\mu \mathrm{M}$ curcumin for $24 \mathrm{~h}$. Next the cells were treated with $300 \mathrm{nM}$ BPDE for $1 \mathrm{~h}$ and harvested immediately $(0 \mathrm{~h})$, and $6,12,16$ or $24 \mathrm{~h}$ later. Twenty micrograms of protein were loaded for Western blot analysis. Levels of cyclin A, but not cyclin E, increased in a time-dependent manner in p53+ cells. Data shown is a representative from two independent experiments. 
A

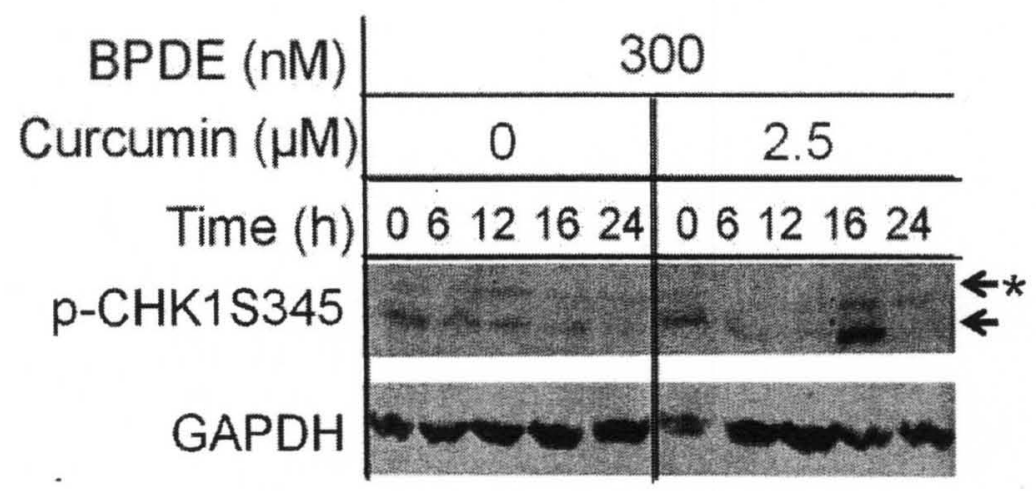

B

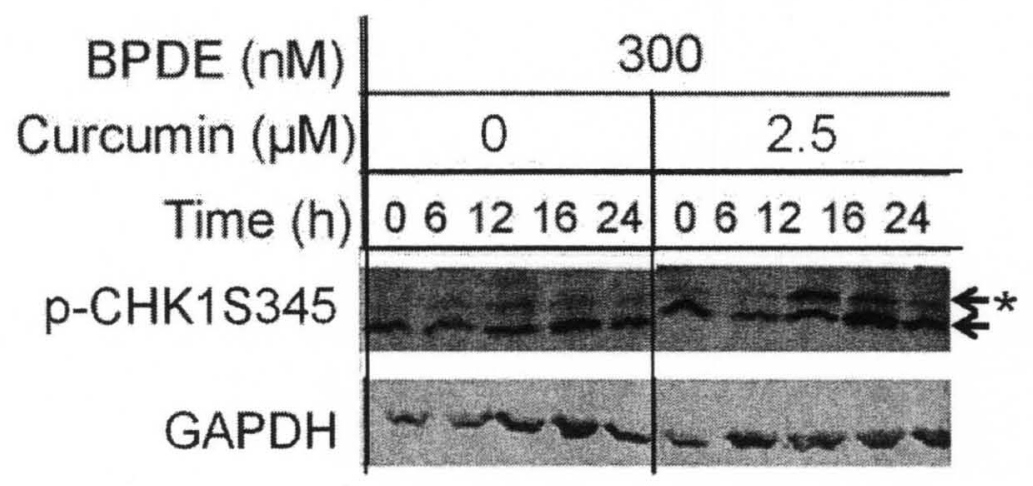

Figure 28. P-CHK1Ser345 is activated in p53-deficient cells after BPDE treatment. A549/LXSN (p53+) (A) and A549/E6 (p53-) (B) were treated with or without $2.5 \mu \mathrm{M}$ curcumin for $24 \mathrm{~h}$. Next the cells were treated with $0,50,100$ or $300 \mathrm{nM}$ BPDE for $1 \mathrm{~h}$ and harvested immediately $(0 \mathrm{~h})$, and $6,12,16$ or $24 \mathrm{~h}$ later. Twenty micrograms of protein was loaded for Western blot analysis. The lower arrow indicates p-CHK1Ser345. * indicates possible phosphorylation of CHK1 at both Ser317 and Ser345. Data shown is a representative from two independent experiments. 
pCHK1Ser345 is active in p53- cells in response to BPDE treatment

Phosphorylated CHK1 at Ser317 and Ser345 (pCHK1S317 and pCHK1Ser345, respectively) signal S phase arrest in response to DNA damage. Therefore we used Western blot to confirm our flow cytometry data which indicated that BPDE-induced DNA damage signaled S phase arrest in p53- cells (Figures 28). P53-expressing or p53deficient A549 cells were either pretreated with or without curcumin for $24 \mathrm{~h}$. Cells were then exposed to $300 \mathrm{nM}$ BPDE for 1 hour. A549 cells were collected at different time points between 0 (immediately after BPDE treatment) and 24 hours. As shown in Figure 26, pCHK1S345 was higher in A549/E6 (p53-) cells than A549/LXSN (p53+) cells in response to $300 \mathrm{nM}$ BPDE. pCHK1Ser345 increased between 0 and 16 hours after 300 nM BPDE in both cell lines with or without curcumin pretreatment. Curcumin pretreatment significantly increased pCHK1Ser345 16 hours after BPDE exposure. Notably, an additional band, which has appeared in other studies [122], was present. I speculate that the additional band is phosphorylation of CHK1 at Ser317 and Ser345.

\section{High BPDE concentrations induce apoptosis in p53-deficient cells}

Based on the evidence that p53- cells began to accumulate in G1 phase in response to $300 \mathrm{nM}$ BPDE, I studied whether BPDE and curcumin induced apoptosis over time. Therefore I collected p53- cells at 36,48 , and 72 hours after $300 \mathrm{nM}$ BPDE (Figure 29) to determine if apoptosis is induced. BPDE treated A549/E6 (p53-) cells accumulated in the sub-G0/G1 compartment in a time-dependent manner (Figure 29A and B). Accumulation of cells in sub-G0/G1 compartment indicates apoptosis. Curcumin pretreatment significantly increased the fraction of p53-cells in sub-G0/G1 compartment $48 \mathrm{~h}$ after $300 \mathrm{nM}$ BPDE. Activated caspases further provide evidence that apoptosis is occurring. Therefore I examined levels of caspase-3 in p53- cells 36, 48 and 72 hours after 300 nM BPDE treatment (Figure 29C). Figure 29C shows that caspase-3 increased 


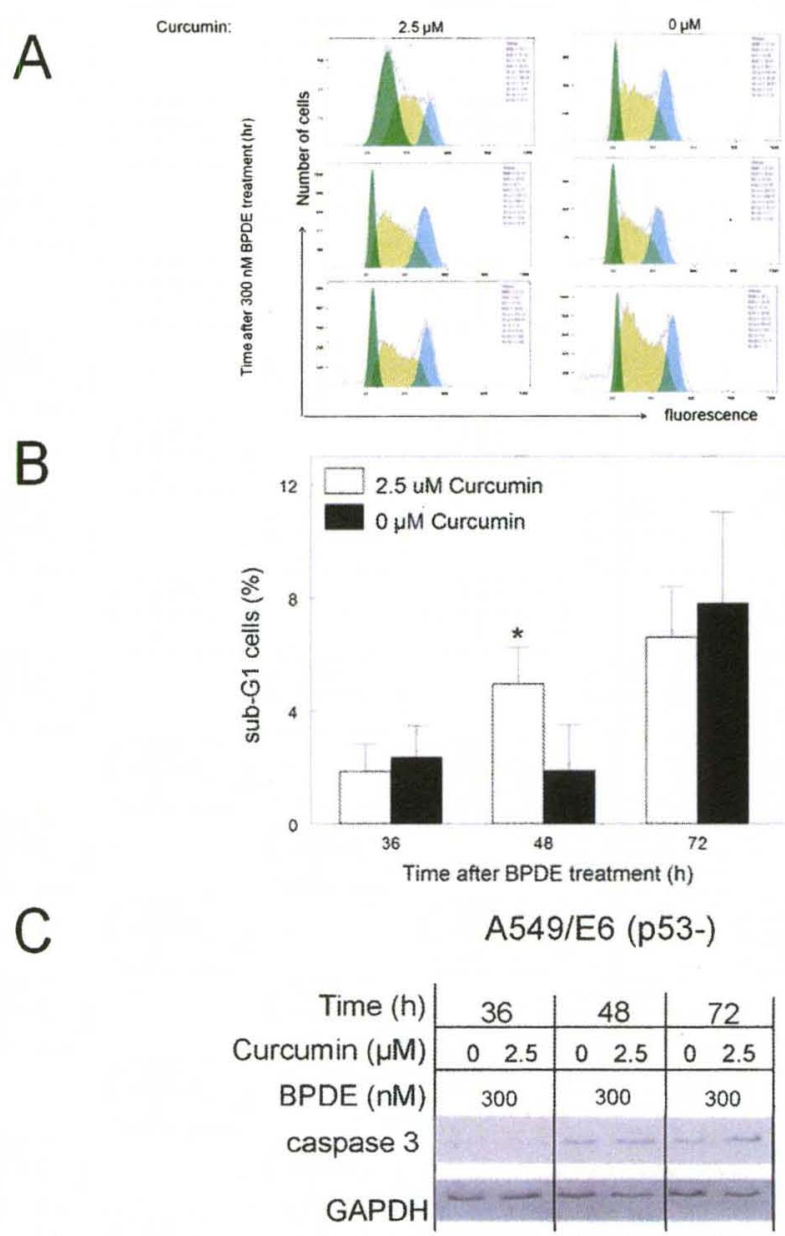

Figure 29. Curcumin enhances apoptosis in apoptosis in A549/E6 cells in response to $300 \mathrm{nM}$ BPDE. A549/E6 (p53-) cells were treated with or without $2.5 \mu \mathrm{M}$ curcumin for 24 h. Then the cells were exposed to $300 \mathrm{nM}$ BPDE for $1 \mathrm{~h}$, harvested immediately 36,48 , or $72 \mathrm{~h}$ after exposure. P53- cells were stained with propidium iodide and DNA content was analyzed using flow cytometry. Figures (A) and (B) represent qualitative and quantitative parameters for cell cycle phase, respectively. Whole caspase- 3 was analyzed by Western Blot $(C)$. Data presented in $(B)$ is means \pm STDEV of three independent experiments. Data shown in (C) is a representative from three independent experiments. ${ }^{*} p<0.05$ for DMSO vs. curcumin pretreatment at indicated time point. 
in a time-dependent manner in p53- cells. 


\section{Discussion}

$\mathrm{BaP}$ is an ubiquitous environmental carcinogen that is metabolized into BPDE. [20;166-168]. BPDE binds and damages DNA. P53 is a key element activated in response to BPDE-induced DNA damage [124]. P53 signals a host of intracellular responses including cell cycle arrest. Induced cell cycle arrest is suggested to allow time for DNA to be repaired. Environmental exposure to BaP and consequently BPDE, however, fails to activate p53 [95;169]. Curcumin reduces BPDE-DNA adducts and induces cell cycle arrest [70;170]. Yet, its exact role in cell cycle progression in response to BPDE-induced DNA damage is unclear.

In the present study, p53 is up-regulated in response to BPDE-induced DNA damage (Figure 22). Additionally, independent studies have shown that CDKN1A is regulated by $p 53$ expression $[51 ; 171 ; 172]$. The results presented support these data which show that $p 53$ levels increase in response to BPDE and CDNK1A is regulated by p53 expression (Figure 22). In addition, to our knowledge, I show for the first time that curcumin further increased p53 up-regulation as well as CDKN1A in response to with lower BPDE concentrations. Therefore curcumin acts as a chemopreventive by enhancing p53 stabilization. In turn, enhanced p53 stabilization allows increases p53 ability to become activated and subsequently signal ability cell cycle arrest. As a result, enhanced cell cycle arrest in response to BPDE-induced damage allows time for DNA repair to occur. Increased levels p53 and p53S15P with lower concentration of BPDE may be a result of curcumin inducing mild oxidative stress. While curcumin is best known to possess anti-oxidant properties, studies characterize curcumin as a prooxidant which damages DNA and enhances chromosomal damage. In mouse-rat hybrid retinal ganglion cell line $\mathrm{N} 18$ cells, Comet assay showed that curcumin at doses as low as $10 \mu \mathrm{M}$ led to a longer DNA migration smear. DNA gel electrophoresis also showed that exposure to $20 \mu \mathrm{M}$ curcumin for 24 and $48 \mathrm{~h}$ induced DNA damage and 
fragmentation in N18 cells. Therefore, curcumin pretreatment may be inducing slight oxidative stress in A549 cells to enhance p53 induction in response to BPDE exposure.

P53 activation signals a number of cellular responses including cell cycle arrest. The induction of the CDKN1A is associated with p53 transactivation. When CDKN1A is present it inhibits the interaction between cyclins and cyclin dependent kinases (CDKs). The inhibition of cyclins and CDKs prevents the phosphorylation and subsequent dissociation of retinoblastoma $(\mathrm{pRb})$ from the transcription factor E2F1[49]. The data revealed a concentration-dependent increase in CDKN1A in response to BPDE-induced damage. On the other hand, protein levels of P-pRbS807/811 decreased in a time- and concentration-dependent manner in response to BPDE (Figure 22A). When A549/LXSN (p53+) cells were pretreated with curcumin, CDKN1A further increased while PpRbS807/811 decreased. These results support previous observations obtained by Aggarwal et al. 2007 which indicate that curcumin enhanced the expression of CDKN1A in MCF7 breast carcinoma cells [164]. Furthermore, our study showed that cell cycle progression is inhibited primarily within S phase; pretreatment with curcumin caused cells to escape $S$ phase arrest much earlier with high BPDE concentrations (>100 nM) (Figure 24A). Thus, the data presented showed an enhance increase in p53, p53Ser15, and CDKN1A and further decrease in p-pRbS807/811 in p53+ cells pretreated with curcumin. These data are further supported by flow cytometry data which showed that p53+ cells arrest in S phase. Taken together, the data presented indicate that curcumin plays a role in cell cycle progression in p53-expressing cells.

Unexpectedly, levels of P-pRbS807/811 also decreased in A549/E6 (p53-) cells in a dose dependent manner in response to BPDE exposure (Figure 22B). This was an interesting finding because we hypothesized that cell cycle progression in the presence of BPDE should be maintained in the absence of $\mathrm{p} 53$ expression. However the data demonstrated that cell cycle arrest is occurring in response to BPDE in a p53- 
independent manner. In support with our results, p53-deficient $\mathrm{H} 1299$ lung carcinoma cells also promoted cell cycle arrest in response to BPDE-induced damage [122]. Levels of P-pRb807/811 were much higher when A549/E6 cells were pretreated with curcumin.

The data shows that p53-deficient cells, like p53-expressing cells, arrest in Sphase (Figure 25). The observation of $S$ phase arrest in response to BPDE-induced DNA damage further support a decrease in P-pRb. However, p53- cells were not cycling with 300 nM BPDE. Instead, p53- cells were stalled in S-phase as shown in Figure 25. Halting in S-phase is sometimes referred to as DNA replication stalling. Studies show that P-Chk1Ser345 is activated in response to DNA replication stalling [122;173]. It is suggest that inefficient repair of stalled DNA replication results in double strand breaks which ultimately signals apoptosis $[155 ; 156]$. The high levels of P-CHK1Ser45 in the p53-defcieint cells and signaling of apoptosis with $300 \mathrm{nM}$ BPDE, implicates that DNA replication is stalled. Thus it would be advantageous to determine if double strand breaks occur in response to $300 \mathrm{nM}$ BPDE. Taken together, the data in Figures 26 and 27 indicate that curcumin may in fact sense the inability the continuous stalled DNA and signal programmed cell death independent of p53 expression.

Overall, the results presented show that curcumin signals cell cycle arrest and apoptosis independent of p53 expression. Induction of cell cycle arrest involves different pathways based on the status of $p 53$. In the presence of $p 53$, CDKN1A is signaled. Yet, when p53 is absent, CHK1 is activated to signal S phase arrest. Curcumin enhanced both pathways. Therefore, curcumin may act as a chemopreventive by activating multiple cell cycle checkpoint mechanism and apoptotic pathways in response to BPDEinduced DNA damage. 


\section{CHAPTER IV}

\section{GENERAL DISCUSSION}

Curcumin is a well known chemopreventive agent which acts against carcinogenesis caused by BPDE-induced DNA damage. Nevertheless, to date it is unclear how curcumin reduces BPDE-induced DNA damage. This research project focused on filling this gap in knowledge by investigating whether curcumin plays a role in p53-mediated cell cycle arrest and DNA repair mechanisms in response to BPDEinduced DNA damage.

In chapter 2, I determined that curcumin does reduce BPDE-DNA adducts in a p53-dependent manner. Surprisingly, I discovered that neither curcumin pretreatment, p53 expression nor exposure to BPDE influenced expression of DNA damage recognition proteins XPC and DDB2 in response to DNA damage. The GSH detoxification pathway, which is the predominantly inactivation pathway for BPDE, was also investigated to determine whether it may influence BPDE-DNA adduct levels in our system. However, I observed that neither curcumin pretreatment, p53 expression, nor BPDE treatment significant changed GST activity, or GSTP and GSH levels. Therefore curcumin pretreatment and p53 expression are altering other mechanisms besides DNA damage recognition and GSH detoxification pathways.

Studies have revealed that XPC and DDB2 are not exclusively regulated by $p 53$ expression [135;138]. In fact, studies show that XPC and DDB2 levels can be regulated by p53 isoforms, such as p63, based on cell type. Additionally, p53 expression has been 
shown to regulate other factors involved in DNA repair of BPDE-induced damage. Namely, p53 is suggested to regulate TFIIH activity and to stimulate the chromatin assembly factor [123;142;143]. TFIIH is responsible for unwinding the damaged DNA, while chromatin assembly factor exposes damaged DNA to DNA repair proteins. Thus, further studies are needed to investigate not only whether p63 influences XPC and DDB2 levels in A549 lung epithelial cells, but also if p53 reduces BPDE-DNA adducts by inducing unwinding of the damaged DNA or activating chromatin assembly factor. Thus, curcumin pretreatment may have a profound impact on p63 or other NER factors in order to significantly reduce BPDE-DNA adducts in a p53-dependent manner.

In chapter 3, I observed that p53, p53 phosphorylated at Ser15 (p53S15), and CDKN1A are up-regulated in a concentration-dependent manner in response to BPDEinduced damage only in p53-expressing cells. Therefore CDKN1A is regulated in a p53dependent manner and signals cell cycle arrest in response to BPDE-induced damage in p53-expressing cells. On the other hand, retinoblastoma protein phosphorylated at Ser807/811 (pRbS807/811) was down-regulated in both p53-expressing and p53deficient cell lines in response to BPDE-induced damage. Thus this BPDE-induced DNA damage can signal cell cycle arrest independently of p53-expression. Additionally, curcumin pretreatment affected levels of p53, p53S15, CDKN1A, and pRbS807/811. Curcumin increased levels of p53, p53S15, and CDKN1A and further decreased pRbS807/811 in p53 expressing cells with lower BPDE concentrations. While p53, p53S15, and CDKN1A were absent in p53 deficient cells, curcumin pretreatment increased pRbS807/811 levels. From these result, it can be concluded that curcumin influences cell cycle progression in both a p53-depdent and p53-independent manner.

I also determined where cells arrested in response to BPDE-induced damage. I discovered that BPDE-induced damage signals S-phase arrest in a p53-independnent manner. While p53-expressing cells escaped S-phase arrest over time, p53-deficient 
cells remained in S-phase arrest and eventually signaled apoptosis. Again, curcumin pretreatment influenced cell cycle arrest and apoptosis in p53-expressing and p53deficient cells. Signaling of apoptosis and cell cycle arrest in both cell lines in response to curcumin pretreatment was influenced by concentration and integrity of p53 expression. From and expression p53-expressing and deficient cells arrested in S-phase in response to BPDE-induced damage. However curcumin pretreatment in both cell lines affected entering and exiting $S$ phase arrest as well as apoptosis in p53 deficient cells.

Two cyclins are associated with S phase. Cyclin E is responsible for the G1-to-S transition, whereas cyclin A pushes cells through S phase. With a high BPDE exposure, I found that in p53-expressing cells cyclin A, but not cyclin E, increased over time. Thus in response to a high concentration of BPDE, p53-expressing cells arrested within S phase. Cyclins A and $E$ did not change in p53-deficient cells with a high BPDE exposure. Taken together, this dissertation shows that curcumin exerts it chemopreventive properties by regulating a host of mechanisms in response to BPDE-induced damage. Curcumin significantly reduced BPDE-DNA adducts in a p53-dependent manner. However, the expected p53 target genes, XPC and DDB2, were not regulated by p53 expression and curcumin pretreatment. Therefore, future studies are needed to determine whether curcumin influences other p53-mediated DNA repair proteins in response to BPDE. In response to BPDE-induced damage, curcumin has an effect on Sphase progression in a p53-independent manner. While curcumin signaled the p53mediated pathway in p53-expressing cells in response to BPDE with lower BPDE concentrations, curcumin also activated the ATR/CHK1 pathway in p53-deficient cells. Curcumin signaled p53-independent apoptosis much earlier. Thus activation of apoptosis in curcumin pretreated p53-deficient cells disposes of DNA damage much earlier. Overall, curcumin is an important chemopreventive agent that plays a protective role against carcinogenesis caused by BPDE-induced DNA damage. 


\section{CHAPTER V}

\section{FUTURE DIRECTIONS}

In chapter 3, it was determined that curcumin reduces BPDE-DNA adduct formation in a p53-dependent manner. However curcumin pretreatment did not influence the rate of DNA repair, XPC, DDB2, or the GSH system in order to decrease BPDE-DNA adducts in a p53-dependent manner. I speculate that the presence of p53 may play a role in either: (1) up-regulating other DNA repair proteins or (2) producing curcumin byproducts which prevent BPDE-DNA adducts.

TFIH helicase subunits, XPB and XPD are needed to unwind the damage DNA complex to expose damage thereby creating the substrate for cleavage (Figure 6). If XPB and XPD were not present damage would not be recognized for cleavage. Several reports show p53 physically binds to the TFIIH helicase subunits, XPB and XPD $[123 ; 141 ; 142]$. Therefore, it would be advantageous to determine whether curcumin pretreatment up-regulates mRNA and protein levels of XPB and XPD in a p53dependent manner immediately after BPDE exposure. Additionally, p53 is suggested to function as a chromatin accessibility factor in NER [143]. Therefore in the presence of DNA damage, p53 signals chromatin relaxation which subsequently extends over the entire genome. Hence, global chromatin relaxation leads to bulky DNA damage recognition over the entire genome by the GGR system. Determining whether curcumin influences the activity chromatin accessibility factor could also explain why BPDE-DNA adducts are lower in p53-expressing cells. 
Curcumin is a very stable compound in cell culture containing $10 \%$ fetal calf serum and in human blood. Less than $20 \%$ of curcumin is decomposed within $1 \mathrm{~h}$, and after incubation for $8 \mathrm{~h}$, about $50 \%$ of curcumin remains in cell culture or human blood. Over time, curcumin is degraded into trans-6-(4'-hydoxy-3'-methoxy-phenyl)-2,4-dioxo-5hexenal, vanillin, ferulic acid, and feruloylmethane. Degradation products of curcumin have been reported to inhibit mutagenesis. Specifically, vanillin is suggested to act as an antimutagen by modifying DNA replication and DNA repair systems after cellular DNA damage. Besides degrading curcumin, commercial curcumin contains three major curcuminoids (curcumin, demethoxycurcumin, and bisdemethoxycurcumin). It was found that the highest antioxidant activity was obtained when the phenolic group was sterically hindered by the introduction of two methyl groups at the othro position. The phenolic group is essential for the free-radical scavenging activity, and the presence of the methoxy group further increases the activity. Therefore, future NMR spectroscopy studies should be implemented to determine whether curcumin or its metabolized and degraded derivatives form adducts with BPDE. In addition, HPLC may be used to determine whether p53 expression plays a role in the production of curcumin derivatives.

By investigating other p53-mediated DNA repair proteins as well as whether p53 expression plays a role in the production of curcumin derivatives, a better understanding will be gained. This insight will help explain why curcumin significantly reduces BPDEDNA adduct formation in a p53-dependent manner. 


\section{REFERENCES}

1. Gasent Blesa JM, Esteban GE, Alberola C, V, Screening and chemoprevention in lung cancer. Clin Transl Oncol 2008;10:274-80.

2. Siegel R, Ward E, Brawley O, Jemal A, Cancer statistics, 2011: The impact of eliminating socioeconomic and racial disparities on premature cancer deaths. $C A$ Cancer J Clin 2011;61:212-36.

3. Kohler BA, Ward E, McCarthy BJ, Schymura MJ, Ries LA, Eheman C, Jemal A, Anderson RN, Ajani UA, Edwards BK, Annual report to the nation on the status of cancer, 1975-2007, featuring tumors of the brain and other nervous system. $J$ Natl Cancer Inst 2011;103:714-36.

4. Jemal A, Bray F, Center MM, Ferlay J, Ward E, Forman D, Global cancer statistics. CA Cancer J Clin 2011;61:69-90.

5. Singh SV, Hu X, Srivastava SK, Singh M, Xia H, Orchard JL, Zaren HA, Mechanism of inhibition of benzo[a]pyrene-induced forestomach cancer in mice by dietary curcumin. Carcinogenesis 1998;19:1357-60.

6. Polasa K, Naidu AN, Ravindranath I, Krishnaswamy K, Inhibition of B(a)P induced strand breaks in presence of curcumin. Mutat Res 2004;557:203-13.

7. Mukundan MA, Chacko MC, Annapurna VV, Krishnaswamy K, Effect of turmeric and curcumin on BP-DNA adducts. Carcinogenesis 1993;14:493-6.

8. Baird WM, Hooven LA, Mahadevan B, Carcinogenic polycyclic aromatic hydrocarbon-DNA adducts and mechanism of action. Environ Mol Mutagen 2005;45:106-14.

9. Mumtaz MM, George JD, Gold KW, Cibulas W, DeRosa CT, ATSDR evaluation of health effects of chemicals. IV. Polycyclic aromatic hydrocarbons (PAHs): understanding a complex problem. Toxicol Ind Health 1996;12:742-971.

10. Farmer PB, Singh R, Kaur B, Sram RJ, Binkova B, Kalina I, Popov TA, Garte S, Taioli E, Gabelova A, Cebulska-Wasilewska A, Molecular epidemiology studies of carcinogenic environmental pollutants. Effects of polycyclic aromatic hydrocarbons (PAHs) in environmental pollution on exogenous and oxidative DNA damage. Mutat Res 2003;544:397-402.

11. Zapponi GA, Attias L, Marcello I, Risk assessment of complex mixtures: some considerations on polycyclic aromatic hydrocarbons in urban areas. $J$ Environ Pathol Toxicol Oncol 1997;16:209-14. 
12. Tarantini A, Maitre A, Lefebvre E, Marques M, Rajhi A, Douki T, Polycyclic aromatic hydrocarbons in binary mixtures modulate the efficiency of benzo[a]pyrene to form DNA adducts in human cells. Toxicology $2011 ; 279: 36-$ 44.

13. Brady CA and Attardi LD, p53 at a glance. J Cell Sci 2010;123:2527-32.

14. Efeyan A and Serrano M, p53: guardian of the genome and policeman of the oncogenes. Cell Cycle 2007;6:1006-10.

15. Hogberg J, Silins I, Stenius U, Chemical induced alterations in p53 signaling. EXS 2009;99:181-208.

16. Piper JT, Singhal SS, Salameh MS, Torman RT, Awasthi YC, Awasthi S, Mechanisms of anticarcinogenic properties of curcumin: the effect of curcumin on glutathione linked detoxification enzymes in rat liver. Int J Biochem Cell Biol 1998;30:445-56.

17. Mannervik B and Danielson UH, Glutathione transferases--structure and catalytic activity. [Review] [233 refs]. CRC Critical Reviews in Biochemistry 23(3):283-337, 1988.

18. Parkin DM, Pisani $P$, Lopez AD, Masuyer $E$, At least one in seven cases of cancer is caused by smoking. Global estimates for 1985 . International Journal of Cancer 59(4):494-504, 1994.

19. Jemal $\mathrm{A}$, Chu KC, Tarone RE, Recent trends in lung cancer mortality in the United States. Journal of the National Cancer Institute 93(4):277-83, 2001.

20. Scherer G, Frank S, Riedel K, Meger-Kossien I, Renner T, Biomonitoring of exposure to polycyclic aromatic hydrocarbons of nonoccupationally exposed persons. Cancer Epidemiology, Biomarkers \& Prevention 9(4):373-80, 2000.

21. Georgiadis P and Kyrtopoulos SA, Molecular epidemiological approaches to the study of the genotoxic effects of urban air pollution. Mutat Res 1999;428:91-8.

22. Castano-Vinyals G, D'Errico A, Malats N, Kogevinas M, Biomarkers of exposure to polycyclic aromatic hydrocarbons from environmental air pollution. Occup Environ Med 2004;61:e12.

23. Bostrom CE, Gerde P, Hanberg A, Jernstrom B, Johansson C, Kyrklund T, Rannug A, Tornqvist M, Victorin K, Westerholm R, Cancer risk assessment, indicators, and guidelines for polycyclic aromatic hydrocarbons in the ambient air. Environ Health Perspect 2002;110 Suppl 3:451-88.

24. Pfeifer GP, Denissenko MF, Olivier M, Tretyakova N, Hecht SS, Hainaut P, Tobacco smoke carcinogens, DNA damage and p53 mutations in smokingassociated cancers. Oncogene 21(48):7435-51, 2002.

25. Hecht SS, Tobacco smoke carcinogens and breast cancer. Environ Mol Mutagen 2002;39:119-26. 
26. Phillips $\mathrm{DH}$, Polycyclic aromatic hydrocarbons in the diet. Mutat Res 1999;443:139-47.

27. Dipple A and Bigger CA, Mechanism of action of food-associated polycyclic aromatic hydrocarbon carcinogens. Mutat Res 1991;259:263-76.

28. Sutandyo N, Nutritional carcinogenesis. Acta Med Indones 2010;42:36-42.

29. Schoket $B$, Monitoring occupational exposure to carcinogens. IARC Scientific Publications (124):341-7, 1993.

30. de Kok TM, Moonen HJ, van DJ, Van Schooten FJ, Methodologies for bulky DNA adduct analysis and biomonitoring of environmental and occupational exposures. J Chromatogr B Analyt Technol Biomed Life Sci 2002;778:345-55.

31. Rubin $\mathrm{H}$, Synergistic mechanisms in carcinogenesis by polycyclic aromatic hydrocarbons and by tobacco smoke: a bio-historical perspective with updates. Carcinogenesis 2001;22:1903-30.

32. Rybicki BA, Nock NL, Savera AT, Tang D, Rundle A, Polycyclic aromatic hydrocarbon-DNA adduct formation in prostate carcinogenesis. Cancer Letters 239(2):157-67, 2006.

33. Phillips DH, Schoket B, Hewer A, Grover PL, DNA adduct formation in human and mouse skin by mixtures of polycyclic aromatic hydrocarbons. IARC Sci PubI 1990;223-9.

34. Dipple A, Khan QA, Page JE, Ponten I, Szeliga J, DNA reactions, mutagenic action and stealth properties of polycyclic aromatic hydrocarbon carcinogens (review). Int J Oncol 1999;14:103-11.

35. Chung JY, Kim JY, Kim WR, Lee SG, Kim YJ, Park JE, Hong YP, Chun YJ, Park YC, Oh S, Yoo KS, Yoo YH, Kim JM, Abundance of aryl hydrocarbon receptor potentiates benzo[a]pyrene-induced apoptosis in Hepa1c1c7 cells via CYP1A1 activation. Toxicology 2007;235:62-72.

36. Gelboin HV, Benzo[alpha]pyrene metabolism, activation and carcinogenesis: role and regulation of mixed-function oxidases and related enzymes. Physiological Reviews 60(4):1107-66, 1980.

37. Fernandes A, Liu T, Amin S, Geacintov NE, Grollman AP, Moriya M, Mutagenic potential of stereoisomeric bay region $(+)$ - and $(-)$-cis-anti-benzo[a]pyrene diol epoxide-N2-2'-deoxyguanosine adducts in Escherichia coli and simian kidney cells. Biochemistry 37(28):10164-72, 1998.

38. Liao KH, Dobrev ID, Dennison JE, Jr., Andersen ME, Reisfeld B, Reardon KF, Campain JA, Wei W, Klein MT, Quann RJ, Yang RS, Application of biologically based computer modeling to simple or complex mixtures. Environ Health Perspect 2002;110 Suppl 6:957-63. 
39. Seematter RJ, Hoffman PG, Kuhn RW, Lockwood LC, Siiteri PK, Comparison of [3H]progesterone and [6,7-3H]-17,21-dimethyl-19-norpregna-4,9-diene-3,20dione for the measurement of progesterone receptors in human malignant tissue. Cancer Research 38(9):2800-6, 1978.

40. Xie XM, Geacintov NE, Broyde S, Origins of conformational differences between cis and trans DNA adducts derived from enantiomeric anti-benzo[a]pyrene diol epoxides. Chem Res Toxicol 1999;12:597-609.

41. Manfredi JJ, The Mdm2-p53 relationship evolves: Mdm2 swings both ways as an oncogene and a tumor suppressor. Genes Dev 2010;24:1580-9.

42. Lee JT and Gu W, The multiple levels of regulation by p53 ubiquitination. Cell Death Differ 2010;17:86-92.

43. Niida $\mathrm{H}$ and Nakanishi $\mathrm{M}$, DNA damage checkpoints in mammals. Mutagenesis 2006;21:3-9.

44. Yonish-Rouach E, Grunwald D, Wilder S, Kimchi A, May E, Lawrence JJ, May P, Oren M, p53-mediated cell death: relationship to cell cycle control. Molecular \& Cellular Biology 13(3):1415-23, 1993.

45. Amaral JD, Xavier JM, Steer CJ, Rodrigues CM, Targeting the p53 pathway of apoptosis. Curr Pharm Des 2010;16:2493-503.

46. Sancar A, Lindsey-Boltz LA, Unsal-Kacmaz K, Linn S, Molecular mechanisms of mammalian DNA repair and the DNA damage checkpoints. [Review] [275 refs]. Annual Review of Biochemistry 73:39-85, 2004.

47. Matsuoka M, Igisu $\mathrm{H}$, Morimoto $\mathrm{Y}$, Phosphorylation of p53 protein in A549 human pulmonary epithelial cells exposed to asbestos fibers. Environmental Health Perspectives 111(4):509-12, 2003.

48. Wang A, Gu J, Judson-Kremer K, Powell KL, Mistry H, Simhambhatla P, Aldaz $\mathrm{CM}$, Gaddis S, MacLeod MC, Response of human mammary epithelial cells to DNA damage induced by BPDE: involvement of novel regulatory pathways. Carcinogenesis 24(2):225-34, 2003.

49. Malumbres $M$ and Barbacid $M$, Cell cycle, CDKs and cancer: a changing paradigm. Nat Rev Cancer 2009;9:153-66.

50. el-Deiry WS, Harper JW, O'Connor PM, Velculescu VE, Canman CE, Jackman J, Pietenpol JA, Burrell M, Hill DE, Wang Y, WAF1/CIP1 is induced in p53-mediated G1 arrest and apoptosis. Cancer Research 54(5):1169-74, 1994.

51. Bukholm IK, Nesland JM, Karesen R, Jacobsen U, Borresen-Dale AL, Interaction between bcl-2 and p21 (WAF1/CIP1) in breast carcinomas with wild-type p53. Int J Cancer 1997;73:38-41. 
52. Lloyd DR and Hanawalt PC, p53-dependent global genomic repair of benzo[a]pyrene-7,8-diol-9,10-epoxide adducts in human cells. Cancer Research 60(3):517-21, 2000.

53. Batty DP and Wood RD, Damage recognition in nucleotide excision repair of DNA. [Review] [111 refs]. Gene 241(2):193-204, 2000.

54. Ford JM, Regulation of DNA damage recognition and nucleotide excision repair: another role for p53. [Review] [61 refs]. Mutation Research 577(1-2):195-202, 2005.

55. Wood RD, Araujo SJ, Ariza RR, Batty DP, Biggerstaff M, Evans E, Gaillard PH, Gunz D, Koberle B, Kuraoka I, Moggs JG, Sandall JK, Shivji MK, DNA damage recognition and nucleotide excision repair in mammalian cells. [Review] [75 refs]. Cold Spring Harbor Symposia on Quantitative Biology 65:173-82, 2000.

56. de Laat WL, Jaspers NG, Hoeijmakers $\mathrm{JH}$, Molecular mechanism of nucleotide excision repair. [Review] [234 refs]. Genes \& Development 13(7):768-85, 1999.

57. Adimoolam S and Ford JM, p53 and DNA damage-inducible expression of the xeroderma pigmentosum group $\mathrm{C}$ gene. Proceedings of the National Academy of Sciences of the United States of America 99(20):12985-90, 2002.

58. Adimoolam $S$ and Ford JM, p53 and regulation of DNA damage recognition during nucleotide excision repair. [Review] [64 refs]. DNA Repair 2(9):947-54, 2003.

59. Fitch ME, Cross IV, Turner SJ, Adimoolam S, Lin CX, Williams KG, Ford JM, The DDB2 nucleotide excision repair gene product p48 enhances global genomic repair in p53 deficient human fibroblasts. DNA Repair 2(7):819-26, 2003.

60. Porter PC, Clark DR, McDaniel LD, McGregor WG, States JC, Telomeraseimmortalized human fibroblasts retain UV-induced mutagenesis and p53mediated DNA damage responses. DNA Repair 5(1):61-70, 2006.

61. Mannervik B and Danielson $\mathrm{UH}$, Glutathione transferases-structure and catalytic activity. [Review] [233 refs]. CRC Critical Reviews in Biochemistry 23(3):283-337, 1988.

62. Hayes JD and Strange RC, Glutathione S-transferase polymorphisms and their biological consequences. [Review] [105 refs]. Pharmacology 61(3):154-66, 2000.

63. Sundberg K, Dreij K, Seidel A, Jernstrom B, Glutathione conjugation and DNA adduct formation of dibenzo[a,I]pyrene and benzo[a]pyrene diol epoxides in V79 cells stably expressing different human glutathione transferases. Chemical Research in Toxicology 15(2): 170-9, 2002.

64. Gate L, Majumdar RS, Lunk A, Tew KD, Influence of glutathione S-transferase pi and p53 expression on tumor frequency and spectrum in mice. International Journal of Cancer 113(1):29-35, 2005. 
65. Godschalk RW, Van Schooten FJ, Bartsch H, A critical evaluation of DNA adducts as biological markers for human exposure to polycyclic aromatic compounds. J Biochem Mol Biol 2003;36:1-11.

66. Jemal A, Chu KC, Tarone RE, Recent trends in lung cancer mortality in the United States. Journal of the National Cancer Institute 93(4):277-83, 2001.

67. Hecht SS, Kassie F, Hatsukami DK, Chemoprevention of lung carcinogenesis in addicted smokers and ex-smokers. Nat Rev Cancer 2009;9:476-88.

68. Cohen V and Khuri FR, Chemoprevention of lung cancer. Curr Opin Pulm Med 2004;10:279-83.

69. Bisht $\mathrm{K}$, Wagner $\mathrm{KH}$, Bulmer $\mathrm{AC}$, Curcumin, resveratrol and flavonoids as antiinflammatory, cyto- and DNA-protective dietary compounds. Toxicology 2010;278:88-100.

70. Duvoix A, Blasius R, Delhalle S, Schnekenburger M, Morceau F, Henry E, Dicato $M$, Diederich M, Chemopreventive and therapeutic effects of curcumin. Cancer Letters 2005;223:181-90.

71. Leu TH and Maa MC, The molecular mechanisms for the antitumorigenic effect of curcumin. Curr Med Chem Anticancer Agents 2002;2:357-70.

72. Ammon HP and Wahl MA, Pharmacology of Curcuma longa. Planta Medica 57(1):1-7, 1991.

73. Jovanovic SV, Boone CW, Steenken S, Trinoga M, Kaskey RB, How curcumin works preferentially with water soluble antioxidants. J Am Chem Soc 2001;123:3064-8.

74. Lin JK, Pan MH, Lin-Shiau SY, Recent studies on the biofunctions and biotransformations of curcumin. Biofactors 2000;13:153-8.

75. Tonnesen $\mathrm{HH}$, Solubility and stability of curcumin in solutions containing alginate and other viscosity modifying macromolecules. Studies of curcumin and curcuminoids. XXX. Pharmazie 2006;61:696-700.

76. Hegge AB, Schuller RB, Kristensen S, Tonnesen $\mathrm{HH}$, In vitro release of curcumin from vehicles containing alginate and cyclodextrin. Studies of curcumin and curcuminoides. XXXIII. Pharmazie 2008;63:585-92.

77. Tonnesen HH, Solubility, chemical and photochemical stability of curcumin in surfactant solutions. Studies of curcumin and curcuminoids, XXVIII. Pharmazie 2002;57:820-4.

78. Tonnesen $\mathrm{HH}$ and Karlsen J, Studies on curcumin and curcuminoids. VI. Kinetics of curcumin degradation in aqueous solution. $Z$ Lebensm Unters Forsch 1985;180:402-4. 
79. Venkatachalam $S$, Denissenko $M$, Wani AA, DNA repair in human cells: quantitative assessment of bulky anti-BPDE-DNA adducts by non-competitive immunoassays. Carcinogenesis 1995;16:2029-36.

80. Li M, Zhang Z, Hill DL, Wang H, Zhang R, Curcumin, a dietary component, has anticancer, chemosensitization, and radiosensitization effects by down-regulating the MDM2 oncogene through the PI3K/mTOR/ETS2 pathway. Cancer Res 2007;67:1988-96.

81. Smith WA and Gupta RC, Use of a microsome-mediated test system to assess efficacy and mechanisms of cancer chemopreventive agents. Carcinogenesis 1996;17:1285-90.

82. Ammon HP and Wahl MA, Pharmacology of Curcuma longa. [Review] [59 refs]. Planta Medica 57(1):1-7, 1991.

83. Shalini VK and Srinivas L, Lipid peroxide induced DNA damage: protection by turmeric (Curcuma longa). Molecular \& Cellular Biochemistry 77(1):3-10, 1987.

84. Duvoix A, Blasius R, Delhalle S, Schnekenburger M, Morceau F, Henry E, Dicato $M$, Diederich M, Chemopreventive and therapeutic effects of curcumin. Cancer Letters 2005;223:181-90.

85. Garg R, Gupta S, Maru GB, Dietary curcumin modulates transcriptional regulators of phase I and phase II enzymes in benzo[a]pyrene-treated mice: mechanism of its anti-initiating action. Carcinogenesis 2008;29:1022-32.

86. Ammon HP and Wahl MA, Pharmacology of Curcuma longa. [Review] [59 refs]. Planta Medica 57(1):1-7, 1991.

87. Perkins S, Verschoyle RD, Hill K, Parveen I, Threadgill MD, Sharma RA, Williams ML, Steward WP, Gescher AJ, Chemopreventive efficacy and pharmacokinetics of curcumin in the $\mathrm{min} /+$ mouse, a model of familial adenomatous polyposis. Cancer Epidemiology, Biomarkers \& Prevention 11(6):535-40, 2002.

88. Pfeifer GP, Denissenko MF, Olivier M, Tretyakova N, Hecht SS, Hainaut P, Tobacco smoke carcinogens, DNA damage and p53 mutations in smokingassociated cancers. Oncogene 2002;21:7435-51.

89. Sram RJ, Beskid O, Rossnerova A, Rossner P, Lnenickova Z, Milcova A, Solansky I, Binkova B, Environmental exposure to carcinogenic polycyclic aromatic hydrocarbons--the interpretation of cytogenetic analysis by FISH. Toxicol Lett 2007;172:12-20.

90. Geacintov NE, Cosman M, Hingerty BE, Amin S, Broyde S, Patel DJ, NMR solution structures of stereoisometric covalent polycyclic aromatic carcinogenDNA adduct: principles, patterns, and diversity. [Review] [165 refs]. Chemical Research in Toxicology 10(2):111-46, 1997. 
91. Gelboin HV, Benzo[alpha]pyrene metabolism, activation and carcinogenesis: role and regulation of mixed-function oxidases and related enzymes. [Review] [340 refs]. Physiological Reviews 60(4):1107-66, 1980.

92. Shimada T, Yamazaki H, Foroozesh M, Hopkins NE, Alworth WL, Guengerich FP, Selectivity of polycyclic inhibitors for human cytochrome P450s 1A1, 1A2, and 1B1. Chemical Research in Toxicology 11(9):1048-56, 1998.

93. Pfeifer GP, Denissenko MF, Olivier M, Tretyakova N, Hecht SS, Hainaut $P$, Tobacco smoke carcinogens, DNA damage and p53 mutations in smokingassociated cancers. [Review] [144 refs]. Oncogene 21(48):7435-51, 2002.

94. Godschalk RW, Ostertag JU, Zandsteeg AM, Van AB, Neuman HA, Van SH, Van Schooten FJ, Impact of GSTM1 on aromatic-DNA adducts and p53 accumulation in human skin and lymphocytes. Pharmacogenetics 11(6):537-43, 2001.

95. Lloyd DR and Hanawalt PC, p53-dependent global genomic repair of benzo[a]pyrene-7,8-diol-9,10-epoxide adducts in human cells. Cancer Research 60(3):517-21, 2000.

96. de Laat WL, Jaspers NG, Hoeijmakers $\mathrm{JH}$, Molecular mechanism of nucleotide excision repair. Genes \& Development 13(7):768-85, 1999.

97. Porter PC, Clark DR, McDaniel LD, McGregor WG, States JC, Telomeraseimmortalized human fibroblasts retain UV-induced mutagenesis and p53mediated DNA damage responses. DNA Repair (Amst) 2006;5:61-70.

98. Adimoolam S and Ford JM, p53 and DNA damage-inducible expression of the xeroderma pigmentosum group $\mathrm{C}$ gene. Proceedings of the National Academy of Sciences of the United States of America 99(20):12985-90, 2002.

99. Tan $T$ and Chu $G, p 53$ Binds and activates the xeroderma pigmentosum DDB2 gene in humans but not mice. Mol Cell Biol 2002;22:3247-54.

100. Singh AK, Sidhu GS, Deepa T, Maheshwari RK, Curcumin inhibits the proliferation and cell cycle progression of human umbilical vein endothelial cell. Cancer Letters 107(1):109-15, 1996.

101. Huang MT, Lou YR, Ma W, Newmark HL, Reuhl KR, Conney AH, Inhibitory effects of dietary curcumin on forestomach, duodenal, and colon carcinogenesis in mice. Cancer Research 54(22):5841-7, 1994.

102. Moragoda L, Jaszewski R, Majumdar AP, Curcumin induced modulation of cell cycle and apoptosis in gastric and colon cancer cells. Anticancer Research 21(2A):873-8, 2001;-Apr.

103. Glockzin S, Ogi FX, Hengstermann A, Scheffner M, Blattner C, Involvement of the DNA repair protein hHR23 in p53 degradation. Molecular \& Cellular Biology 23(24):8960-9, 2003. 
104. Alexandrov K, Cascorbi I, Rojas M, Bouvier G, Kriek E, Bartsch H, CYP1A1 and GSTM1 genotypes affect benzo[a]pyrene DNA adducts in smokers' lung: comparison with aromatic/hydrophobic adduct formation. [Review] [75 refs]. Carcinogenesis 23(12):1969-77, 2002.

105. Quinones LA, Irarrazabal CE, Rojas CR, Orellana CE, Acevedo C, Huidobro C, Varela NE, Caceres DD, Joint effect among p53, CYP1A1, GSTM1

polymorphism combinations and smoking on prostate cancer risk: an exploratory genotype-environment interaction study. Asian Journal of Andrology 8(3):349-55, 2006.

106. lersel ML, Ploemen JP, Struik I, van AC, Keyzer AE, Schefferlie JG, van Bladeren PJ, Inhibition of glutathione S-transferase activity in human melanoma cells by alpha,beta-unsaturated carbonyl derivatives. Effects of acrolein, cinnamaldehyde, citral, crotonaldehyde, curcumin, ethacrynic acid, and trans-2hexenal. Chemico-Biological Interactions 102(2):117-32, 1996.

107. Quinones LA, Irarrazabal CE, Rojas CR, Orellana CE, Acevedo C, Huidobro C, Varela NE, Caceres DD, Joint effect among p53, CYP1A1, GSTM1 polymorphism combinations and smoking on prostate cancer risk: an exploratory genotype-environment interaction study. Asian Journal of Andrology 8(3):349-55, 2006.

108. Alexandrov K, Cascorbi I, Rojas M, Bouvier G, Kriek E, Bartsch H, CYP1A1 and GSTM1 genotypes affect benzo[a]pyrene DNA adducts in smokers' lung: comparison with aromatic/hydrophobic adduct formation. [Review] [75 refs]. Carcinogenesis 23(12):1969-77, 2002.

109. Godschalk RW, Ostertag JU, Zandsteeg AM, Van AB, Neuman HA, Van SH, Van Schooten FJ, Impact of GSTM1 on aromatic-DNA adducts and p53 accumulation in human skin and lymphocytes. Pharmacogenetics 11(6):537-43, 2001.

110. Schwartz JL and Shklar G, Glutathione inhibits experimental oral carcinogenesis, p53 expression, and angiogenesis. Nutr Cancer 1996;26:229-36.

111. Haouzi D, Lekehal M, Tinel M, Vadrot N, Caussanel L, Letteron P, Moreau A, Feldmann G, Fau D, Pessayre D, Prolonged, but not acute, glutathione depletion promotes Fas-mediated mitochondrial permeability transition and apoptosis in mice. Hepatology 2001;33:1181-8.

112. MacLeod $M C$ and Lew $L, A$ rapid, spectrophotometric assay for the integrity of diol epoxides. Carcinogenesis 1988;9:2133-5.

113. Rahman I, Kode A, Biswas SK, Assay for quantitative determination of glutathione and glutathione disulfide levels using enzymatic recycling method. Nat Protoc 2006;1:3159-65.

114. Deshpande SS and Maru GB, Effects of curcumin on the formation of benzo[a]pyrene derived DNA adducts in vitro. Cancer Lett 1995;96:71-80. 
115. Choudhuri T, Pal S, Das T, Sa G, Curcumin selectively induces apoptosis in deregulated cyclin D1-expressed cells at G2 phase of cell cycle in a p53dependent manner. Journal of Biological Chemistry 280(20):20059-68, 2005.

116. Aggarwal BB, Banerjee S, Bharadwaj U, Sung B, Shishodia S, Sethi G, Curcumin induces the degradation of cyclin $E$ expression through ubiquitindependent pathway and up-regulates cyclin-dependent kinase inhibitors p21 and p27 in multiple human tumor cell lines. Biochemical Pharmacology 2007;73:1024-32.

117. Lloyd DR and Hanawalt PC, p53-dependent global genomic repair of benzo[a]pyrene-7,8-diol-9,10-epoxide adducts in human cells. Cancer Research 60(3):517-21, 2000.

118. Sugasawa K, Masutani C, Uchida A, Maekawa T, van der Spek PJ, Bootsma D, Hoeijmakers JH, Hanaoka F, HHR23B, a human Rad23 homolog, stimulates' XPC protein in nucleotide excision repair in vitro. Molecular \& Cellular Biology 16(9):4852-61, 1996.

119. Ford JM, Regulation of DNA damage recognition and nucleotide excision repair: another role for p53. Mutation Research 577(1-2):195-202, 2005.

120. Srivastava SK, Watkins SC, Schuetz E, Singh SV, Role of glutathione conjugate efflux in cellular protection against benzo[a]pyrene-7,8-diol-9,10-epoxide-induced DNA damage. Mol Carcinog 2002;33:156-62.

121. Bi X, Barkley LR, Slater DM, Tateishi S, Yamaizumi M, Ohmori H, Vaziri C, Rad18 regulates DNA polymerase kappa and is required for recovery from Sphase checkpoint-mediated arrest. Mol Cell Biol 2006;26:3527-40.

122. Guo N, Faller DV, Vaziri C, Carcinogen-induced S-phase arrest is Chk1 mediated and caffeine sensitive. Cell Growth Differ 2002;13:77-86.

123. Wang QE, Zhu Q, Wani MA, Wani G, Chen J, Wani AA, Tumor suppressor p53 dependent recruitment of nucleotide excision repair factors XPC and TFIIH to DNA damage. DNA Repair (Amst) 2003;2:483-99.

124. Tampio $M$, Loikkanen J, Myllynen P, Mertanen A, Vähäkangas KH, Benzo(a)pyrene increases phosphorylation of p53 at serine 392 in relation to p53 induction and cell death in MCF-7 cells. Toxicology Letters 2008;178:152-9.

125. Manna S, Mukherjee S, Roy A, Das S, Panda CK, Tea polyphenols can restrict benzo[a]pyrene-induced lung carcinogenesis by altered expression of $p 53-$ associated genes and $\mathrm{H}$-ras, c-myc and cyclin D1. J Nutr Biochem 2009;20:33749.

126. Xiao $\mathrm{H}$ and Singh SV, p53 regulates cellular responses to environmental carcinogen benzo[a]pyrene-7,8-diol-9,10-epoxide in human lung cancer cells. Cell Cycle 2007;6:1753-61. 
127. Chiang $\mathrm{HC}$ and Tsou TC, Arsenite enhances the benzo[a]pyrene diol epoxide (BPDE)-induced mutagenesis with no marked effect on repair of BPDE-DNA adducts in human lung cells. Toxicol In Vitro 2009;23:897-905.

128. Azuine MA and Bhide SV, Chemopreventive effect of turmeric against stomach and skin tumors induced by chemical carcinogens in Swiss mice. Nutr Cancer 1992;17:77-83.

129. Garg R and Maru G, Dietary curcumin enhances benzo(a)pyrene-induced apoptosis resulting in a decrease in BPDE-DNA adducts in mice. J Environ Pathol Toxicol Oncol 2009;28:121-31.

130. Watson JL, Greenshields A, Hill R, Hilchie A, Lee PW, Giacomantonio CA, Hoskin DW, Curcumin-induced apoptosis in ovarian carcinoma cells is p53independent and involves p38 mitogen-activated protein kinase activation and downregulation of Bcl-2 and survivin expression and Akt signaling. Mol Carcinog 2010;49:13-24.

131. Moos PJ, Edes K, Mullally JE, Fitzpatrick FA, Curcumin impairs tumor suppressor p53 function in colon cancer cells. Carcinogenesis 2004;25:1611-7.

132. Kruse JP and Gu W, Modes of p53 regulation. Cell 2009;137:609-22.

133. MacLeod MC, Qing WG, Powell KL, Daylong A, Evans FE, Reaction of nontoxic, potentially chemopreventive purinethiols with a direct-acting, electrophilic carcinogen, benzo[a]pyrene-7,8-diol 9,10-epoxide. Chem Res Toxicol 1993;6:159-67.

134. MacLeod MC, Stewart E, Daylong A, Lew LK, Evans FE, Reaction of a chemotherapeutic agent, 6-mercaptopurine, with a direct-acting, electrophilic carcinogen, benzo[a]pyrene-7,8-diol 9,10-epoxide. Chem Res Toxicol 1991;4:453-62.

135. Shen S, Lee J, Weinfeld M, Le XC, Attenuation of DNA damage-induced p53 expression by arsenic: a possible mechanism for arsenic co-carcinogenesis. Mol Carcinog 2008;47:508-18.

136. Prost S, Lu P, Caldwell H, Harrison D, E2F regulates DDB2: consequences for DNA repair in Rb-deficient cells. Oncogene 2007;26:3572-81.

137. Ferguson $\mathrm{BE}$ and $\mathrm{Oh} \mathrm{DH}$, Proficient global nucleotide excision repair in human keratinocytes but not in fibroblasts deficient in p53. Cancer Res 2005;65:8723-9.

138. Oh DH and Yeh $\mathrm{K}$, Differentiating human keratinocytes are deficient in $\mathrm{p} 53$ but retain global nucleotide excision repair following ultraviolet radiation. DNA Repair (Amst) 2005;4:1149-59.

139. Ferguson-Yates BE, Li H, Dong TK, Hsiao JL, Oh DH, Impaired repair of cyclobutane pyrimidine dimers in human keratinocytes deficient in p53 and p63. Carcinogenesis 2008;29:70-5. 
140. Shiyanov P, Hayes SA, Donepudi M, Nichols AF, Linn S, Slagle BL, Raychaudhuri $P$, The naturally occurring mutants of DDB are impaired in stimulating nuclear import of the p125 subunit and E2F1-activated transcription. Mol Cell Biol 1999;19:4935-43.

141. Leveillard T, Andera L, Bissonnette N, Schaeffer L, Bracco L, Egly JM, Wasylyk $\mathrm{B}$, Functional interactions between p53 and the TFIIH complex are affected by tumour-associated mutations. EMBO J 1996;15:1615-24.

142. Wang XW, Vermeulen W, Coursen JD, Gibson M, Lupold SE, Forrester K, Xu G, Elmore L, Yeh $\mathrm{H}$, Hoeijmakers JH, Harris CC, The XPB and XPD DNA helicases are components of the p53-mediated apoptosis pathway. Genes Dev $1996 ; 10: 1219-32$.

143. Rubbi CP and Milner $\mathrm{J}, \mathrm{p} 53$ is a chromatin accessibility factor for nucleotide excision repair of DNA damage. EMBO J 2003;22:975-86.

144. Sayer JM, Whalen DL, Jerina DM, Chemical strategies for the inactivation of bayregion diol epoxides, ultimate carcinogens derived from polycyclic aromatic hydrocarbons. Drug Metab Rev 1989;20:155-82.

145. Wood AW, Huang MT, Chang RL, Newmark HL, Lehr RE, Yagi H, Sayer JM, Jerina DM, Conney $\mathrm{AH}$, Inhibition of the mutagenicity of bay-region diol epoxides of polycyclic aromatic hydrocarbons by naturally occurring plant phenols: exceptional activity of ellagic acid. Proc Natl Acad Sci U S A 1982;79:5513-7.

146. Romert $L$, Jansson $T$, Curvall $M$, Jenssen $D$, Screening for agents inhibiting the mutagenicity of extracts and constituents of tobacco products. Mutat Res 1994;322:97-110.

147. Huetz $P$, Mavaddat N, Mavri J, Reaction between ellagic acid and an ultimate carcinogen. J Chem Inf Model 2005;45:1564-70.

148. Lagerqvist A, Hakansson D, Frank H, Seidel A, Jenssen D, Structural requirements for mutation formation from polycyclic aromatic hydrocarbon dihydrodiol epoxides in their interaction with food chemopreventive compounds. Food Chem Toxicol 2011;49:879-86.

149. Denissenko MF, Cahill J, Koudriakova TB, Gerber N, Pfeifer GP, Quantitation and mapping of aflatoxin B1-induced DNA damage in genomic DNA using aflatoxin B1-8,9-epoxide and microsomal activation systems. Mutation Research 425(2):205-11, 1999.

150. Geacintov NE, Cosman M, Hingerty BE, Amin S, Broyde S, Patel DJ, NMR solution structures of stereoisometric covalent polycyclic aromatic carcinogenDNA adduct: principles, patterns, and diversity. [Review] [165 refs]. Chemical Research in Toxicology 10(2):111-46, 1997.

151. Gelboin HV, Benzo[alpha]pyrene metabolism, activation and carcinogenesis: role and regulation of mixed-function oxidases and related enzymes. [Review] [340 refs]. Physiological Reviews 60(4):1107-66, 1980. 
152. Pfeifer GP, Denissenko MF, Olivier M, Tretyakova N, Hecht SS, Hainaut $P$, Tobacco smoke carcinogens, DNA damage and p53 mutations in smokingassociated cancers. [Review] [144 refs]. Oncogene 21(48):7435-51, 2002.

153. Suzuki K, Inageda K, Nishitai G, Matsuoka M, Phosphorylation of p53 at serine 15 in A549 pulmonary epithelial cells exposed to vanadate: involvement of ATM pathway. Toxicology \& Applied Pharmacology 220(1):83-91, 2007.

154. Harris SL and Levine AJ, The p53 pathway: positive and negative feedback loops. [Review] [100 refs]. Oncogene 24(17):2899-908, 2005.

155. Smith J, Tho LM, Xu N, Gillespie DA, The ATM-Chk2 and ATR-Chk1 pathways in DNA damage signaling and cancer. Adv Cancer Res 2010;108:73-112.

156. Reinhardt $\mathrm{HC}$ and Yaffe $\mathrm{MB}$, Kinases that control the cell cycle in response to DNA damage: Chk1, Chk2, and MK2. Curr Opin Cell Biol 2009;21:245-55.

157. Tampio M, Loikkanen J, Myllynen P, Mertanen A, VShSkangas KH, Benzo(a)pyrene increases phosphorylation of p53 at serine 392 in relation to p53 induction and cell death in MCF-7 cells. Toxicology Letters 2008;178:152-9.

158. Levine AJ, p53, the cellular gatekeeper for growth and division. [Review] [55 refs]. Cell 88(3):323-31, 1997.

159. el-Deiry WS, Harper JW, O'Connor PM, Velculescu VE, Canman CE, Jackman J, Pietenpol JA, Burrell M, Hill DE, Wang Y, WAF1/CIP1 is induced in p53-mediated G1 arrest and apoptosis. Cancer Research 54(5):1169-74, 1994.

160. Abraham RT, Cell cycle checkpoint signaling through the ATM and ATR kinases. Genes Dev 2001;15:2177-96.

161. Azuine MA and Bhide SV, Adjuvant chemoprevention of experimental cancer: catechin and dietary turmeric in forestomach and oral cancer models. $J$ Ethnopharmacol 1994;44:211-7.

162. Ravindran J, Prasad S, Aggarwal BB, Curcumin and cancer cells: how many ways can curry kill tumor cells selectively? AAPS J 2009;11:495-510.

163. Ammon HP and Wahl MA, Pharmacology of Curcuma longa. [Review] [59 refs]. Planta Medica 57(1):1-7, 1991.

164. Aggarwal BB, Banerjee S, Bharadwaj U, Sung B, Shishodia S, Sethi G, Curcumin induces the degradation of cyclin $E$ expression through ubiquitindependent pathway and up-regulates cyclin-dependent kinase inhibitors p21 and p27 in multiple human tumor cell lines. Biochemical Pharmacology 2007;73:1024-32.

165. Chen $A, X u J$, Johnson $A C$, Curcumin inhibits human colon cancer cell growth by suppressing gene expression of epidermal growth factor receptor through reducing the activity of the transcription factor Egr-1. Oncogene 25(2):278-87, 2006. 
166. Schoket B, Monitoring occupational exposure to carcinogens. [Review] [27 refs]. IARC Scientific Publications (124):341-7, 1993.

167. Rybicki BA, Nock NL, Savera AT, Tang D, Rundle A, Polycyclic aromatic hydrocarbon-DNA adduct formation in prostate carcinogenesis. [Review] [81 refs]. Cancer Letters 239(2):157-67, 2006.

168. Tokiwa H, Sera N, Horikawa K, Nakanishi $Y$, Shigematu N, The presence of mutagens/carcinogens in the excised lung and analysis of lung cancer induction. Carcinogenesis 14(9):1933-8, 1993.

169. Hirao A, Kong YY, Matsuoka S, Wakeham A, Ruland J, Yoshida H, Liu D, Elledge SJ, Mak TW, DNA damage-induced activation of p53 by the checkpoint kinase Chk2. Science 2000;287:1824-7.

170. Garg R, Gupta S, Maru GB, Dietary curcumin modulates transcriptional regulators of phase I and phase II enzymes in benzo[a]pyrene-treated mice: mechanism of its anti-initiating action. Carcinogenesis 2008;29:1022-32.

171. Choi BH, Kim CG, Bae YS, Lim Y, Lee YH, Shin SY, p21 Waf1/Cip1 expression by curcumin in U-87MG human glioma cells: role of early growth response-1 expression. Cancer Res 2008;68:1369-77.

172. Niculescu AB, III, Chen $X$, Smeets $M$, Hengst $L$, Prives $C$, Reed SI, Effects of p21(Cip1/Waf1) at both the G1/S and the G2/M cell cycle transitions: pRb is a critical determinant in blocking DNA replication and in preventing endoreduplication. Mol Cell Biol 1998;18:629-43.

173. Chen B, Simpson DA, Zhou Y, Mitra A, Mitchell DL, Cordeiro-Stone M, Kaufmann WK, Human papilloma virus type16 E6 deregulates $\mathrm{CHK} 1$ and sensitizes human fibroblasts to environmental carcinogens independently of its effect on p53. Cell Cycle 2009;8:1775-87. 
APPENDIX

\section{List of Abbreviations}

ATM

ATR

AP

$\mathrm{BaP}$

BPDE

CDK

CDKI

CDKN1A

CHK1

CHK2

DDB1

DDB2

DMEM

DMSO

ECF

ECL

EDTA

GADD45

GAPDH

GGR ataxia telangiectasia, mutated

ATR, ATM- and Rad3-related

alkaline phosphatase

benzo(a)pyrene

7R,8S-dihydroxy-9S, 10R-epoxy-7,8,9,10-

tetrahydrobenzo[a]pyrene

cyclin dependent kinase

cyclin dependent kinase inhibitor

cyclin dependent kinase inhibitor $1 \mathrm{~A}$ (also known as p21 ${ }^{\text {CIPMAF1 }}$ )

checkpoint kinase 1

checkpoint kinase

DNA damage binding protein 1

DNA damage binding protein 2

Dulbecco/Nogt modified Eagle's minimal essential medium

dimethyl sulfoxide

enhanced chemifluorescence

enhanced chemiluminescence

ethylene diamine tetraacetic acid

Growth arrest and DNA damage protein 45

glyceradehyde-3-phosphate dehydrogenase

Global genomic repair 


\begin{tabular}{|c|c|}
\hline GSH & glutathione \\
\hline GST & Glutathione-(S)-transferase \\
\hline GSTA & Glutathione-(S)-transferase alpha \\
\hline GSTM & Glutathione-(S)-transferase mu \\
\hline GSTP & Glutathione-(S)-transferase pi \\
\hline HDM2 & human double minute gene 2 \\
\hline HPV & human papillomavirus \\
\hline HRP & horse radish peroxidase \\
\hline MDM2 & mouse double minute gene 2 \\
\hline MRP & multidrug resistance protein \\
\hline $\mathrm{NaCl}$ & sodium chloride \\
\hline NER & nucleotide excision repair \\
\hline PAH & polycyclic aromatic hydrocarbon \\
\hline PBS & phosphate buffered saline \\
\hline Phospho-pRb & phosphorylated retinoblastoma protein \\
\hline PMSF & phenylmethylsulphonylfluoride \\
\hline $\mathrm{pRb}$ & retinoblastoma protein \\
\hline $\mathrm{Rb}$ & retinoblastoma \\
\hline RNase A & ribonuclease $A$ \\
\hline SDS & sodium dodecyl sulfate \\
\hline SDS-PAGE & sodium dodecyl sulfate-polyacrylamide gel electrophoresis \\
\hline Ser & serine \\
\hline TBST & Tris buffered saline with Tween-20 \\
\hline TCR & transcription couple repair \\
\hline TFIIH & transcription factor II group $\mathrm{H}$ \\
\hline TE & Tris-ethylene diamine tetraacetic acid \\
\hline
\end{tabular}




$\begin{array}{ll}\text { UV } & \text { ultraviolet } \\ \text { XPB } & \text { Xeroderma pigmentosum group B } \\ \text { XPD } & \text { Xeroderma pigmentosum group D } \\ \text { XPC } & \text { Xeroderma pigmentosum group C }\end{array}$




\section{CURRICULUM VITAE}

\section{Erica Nicole Rogers}

\section{OFFICE ADDRESS}

University of Louisville

School of Medicine

Department of Pharmacology and Toxicology

505 South Hancock Street

Clinical and Translational Building, Room 352-C

work: (502) 852-2405

enroge01@gwise.louisville.edu

\section{HOME ADDRESS}

3626 Hurstbourne Ridge Blvd.

Louisville, KY 40299

${ }^{*}$ Cell: (850) 294-7651

*preferred contact number

\section{EDUCATION}

University of Louisville, Louisville, KY

Ph.D. candidate, anticipated graduation date: August 2011

Discipline of Study: Pharmacology and Toxicology

University of Louisville, Louisville, KY

Master's of Science, May 2008

Discipline of Study: Pharmacology and Toxicology

Florida Agricultural and Mechanical University, Tallahassee, FL

Bachelor's of Science, December 2004

Major: chemistry Minor: biology

\section{SCIENTIFIC EXPERIENCE}

2008-present Ph.D. candidate, Department of Pharmacology and Toxicology, University of Louisville

Dissertation Project: The regulation of DNA damage by curcumin Principal investigator: J. Christopher States, Ph.D.

2005-2007 Master's student, Department of Pharmacology and Toxicology, University of Louisville Thesis Project: Modulation of DNA damage response by curcumin Principal investigator: J. Christopher States, Ph.D. 
Research intern, Department of Chemical Engineering, Clemson University

Research Project: Synthesis of poly(phenyleneethylene) polymers by way of a multi-step process

Principal Investigator: David Bruce, Ph.D.

2001

Research Intern, Department of Mathematics, Florida A\&M University Research Project: Creation of an algorithm to compute Voronoi diagrams Principal Investigator: Bruno Guerrieri, Ph.D.

RESEARCH ACTIVITIY

2008-2011 Grants Funded

Curcumin inhibits BPDE-induced damage by lowering the threshold of p53 activation. National Institutes of Health, National Institutes of Environmental Health May 2009. (Grant Number: 5F31ES016719-02)

\title{
HONORS/AWARDS
}

2010 Outstanding Student Leadership Award, National Society of Toxicology

2010 Honorable Mention, National Society of Toxicology Molecular Biology Specialty Section Student poster

2008 Best Ph.D. Graduate Platform Award, Ohio Valley Society of Toxicology

2007 Graduate Student Travel award Recipient, 2008 Annual Meeting for Society of Toxicology

$2002 \quad 3^{\text {rd }}$ place at the Florida Georgia Louis Stokes Minority Participation (FGLSAMP) Regional Research Conference Program, Tampa, FL $2001 \quad 1^{\text {st }}$ place at the Florida Georgia Louis Stokes Minority Participation (FGLSAMP) Summer Research Program, Florida A\&M University, Tallahassee, FL

\author{
FELLOWSHIPS \\ 2008-present Recipient of the Ruth L. Kirschstein National Research Service Award for \\ Individual Predoctoral Fellowships (F31) to Promote Diversity in Health- \\ Related Research \\ 2007-2008 U of L Environmental Health Sciences Predoctoral Training Program \\ Training Grant (T32 ES011564) \\ 2005-2007 Integrated Programs in Biomedical Sciences (IPIBS) Fellowship \\ Recipient, University of Louisville \\ 2000-2004 Biology and Naval Research (BIONR) Scholar, Florida A\&M University \\ 2000-2004 Florida Bright Future Scholarship \\ 2000-2004 George W. Gore Scholarship, Florida A\&M University \\ PROFESSIONAL APPOINTMENTS/SERVICE \\ 2010-2011 Student representative, Microbiology and Immunology Search Committee \\ University of Louisville, Louisville, $\mathrm{KY}$ \\ 2009-2010 Secretary, Society of Toxicology Regional Chapter/ Special Interest \\ Group Graduate Committee \\ 2009-2010 Member, Society of Toxicology Student Advisory Board \\ 2009-2010 \\ 2008-2010 \\ Student Representative, Society of Toxicology Education Committee \\ 2008-2009 \\ Student representative, Ohio Valley Society of Toxicology (OVSOT) \\ Coordinator and organizer, Ohio Valley Society of Toxicology Summer \\ Student Meeting
}


2007-2008 Graduate student volunteer, Society of Toxicology Diversity Initiative Committee

2009-2010 Secretary, Society of Toxicology Regional Chapter/ Special Interest Group Graduate Committee

2009-2010 Treasurer, Black Biomedical Graduate Student Organization (BBGSO), University of Louisville

2007-2008 Secretary, Black Biomedical Graduate Student Organization (BBGSO), University of Louisville

2004-2004 College tutor, Department of Chemistry, Florida A\&M University

2003-2004 Middle school science teacher aide, Science Students Together Reaching Instructional Diversity \& Excellence (SSTRIDE), School of Medicine, Florida State University

\section{SCIENTIFIC MEMBERSHIPS}

Society of Toxicology, national

Society of Toxicology, Ohio Valley regional chapter

\section{PUBLISHED ABSTRACTS}

1. Rogers EN, Jiang GH, States JC. Curcumin Regulates Cell Cycle Progression in Response to DNA Damage. Abstract 2235. The Toxicologist, Volume 120, Number S-2, March 2011.

2. Rogers EN, Jiang GH, States JC. Curcumin Regulates Cell Cycle Progression in Response to DNA Damage. Abstract 1109.The Toxicologist, Volume 114, Number S-1, March 2010.

3. Rogers EN, Jiang GH, States JC. Curcumin Regulates Cell Cycle Progression and DNA Repair Proteins in a P53-Dependent Manner. Abstract 1084. The Toxicologist, Volume 108, Number 1, March 2009.

4. Rogers EN, Jiang GH, Belshoff AC, States JC. Curcumin enhances p53-mediated responses to BPDE-induced DNA damage. Proceedings of the 97th Annual Meeting of the American Association for Cancer Research; 2008 Apr 12-16; Washington, DC. San Diego (CA) AACR; 2008. p 7. Abstract nr 3824

5. Rogers EN, Jiang GH, States JC. Curcumin lowers the threshold of p53 activation and subsequent induction of DNA damage recognition proteins XPC and DDB2. Abstract 871, The Toxicologist, Volume 101, Number 2, March 2008.

\section{LOCAL/REGIONAL MEETING PROCEEDINGS}

1. Rogers, Erica, Jiang, GouHui, States, J. Christopher. Curcumin Regulates Cell Cycle Progression in Response to DNA Damage in a p53-dependent manner. Midwest DNA Repair Symposium, 2010, Louisville, KY (USA).

2. Erica Rogers, GouHui Jiang, J. Christopher States. Curcumin Regulates Cell Cycle Progression in Response to DNA Damage. Ohio Valley Society of Toxicology Meeting, 2009, Cincinnati, OH (USA). 
3. Erica Rogers, J. Christopher States. Curcumin Regulates Cell Cycle Progression in Response to DNA Damage. Research! Louisville Symposium, 2009, Louisville, KY (USA).

4. Erica Rogers, GouHui Jiang, J. Christopher States. Curcumin Regulates Cell Cycle Progression in Response to DNA Damage. Midwest DNA Repair Symposium, 2009. Ann Arbor, MI (USA).

5. Erica Rogers, GouHui Jiang, J. Christopher States. Curcumin lowers the threshold of p53 activation by inducing DNA damage recognition proteins XPC and DDB2. Ohio Valley Society of Toxicology Meeting, 2008, Dayton OH (USA).

6. Erica Rogers, GouHui Jiang, J. Christopher States. Curcumin regulates cell cycle progression and DNA repair proteins in a p53-dependent manner. James Brown Cancer Center Annual Retreat, 2008, Louisville, KY (USA).

7. Erica Rogers, GouHui Jiang, J. Christopher States. Curcumin regulates cell cycle progression and DNA repair proteins in a p53-dependent manner. Research! Louisville Symposium, 2008, Louisville, KY (USA).

8. Rogers, Erica, Jiang, GouHui, States, J. Christopher. Curcumin reduces BPDEadduct levels by inducing cell cycle arrest and DNA damage proteins in A549 lung epithelial cells. Midwest DNA Repair Symposium, 2009, Pittsburgh, PA (USA).

9. Erica Rogers, GouHui Jiang, J. Christopher States. Curcumin lowers the threshold of p53 activation by inducing DNA damage recognition proteins XPC and DDB2. Ohio Valley Society of Toxicology Meeting, November 2007, Indianapolis, IN (USA).

10. Erica Rogers, GouHui Jiang, J. Christopher States. Curcumin lowers the threshold of p53 activation and subsequent induction of DNA damage recognition proteins XPC and DDB2. James Brown Cancer Center Annual Retreat, 2007, Louisville, KY (USA).

11. Erica Rogers, GouHui Jiang, J. Christopher States._Curcumin Lowers the Threshold of p53 Activation and Subsequent Induction of DNA Damage Recognition Proteins XPC and DDB2. Research! Louisville Symposium, 2007, Louisville, KY (USA).

VOLUNTEER SERVICE

2005-present Health education youth mentor, Black Achievers and YMCA, Louisville, KY

2005-2010 Relay for Life participant, West Jefferson division, Louisville, KY.

2008-2010 Accounting committee, Relay for Life, Jefferson County division, Louisville, KY

2006-2008 Mission Delivery Chair, Relay for Life, West Jefferson division, Louisville, KY

2007-2007 Cancer Education Speaker, Lampkins Chapel Christian Methodist Episcopal Church Women's Ministry, Louisville, K 